Fissile Materials Disposition Program

\title{
Plutonium Immobilization Project Development and Testing Baseline and Progress Monthly Report December 2000
}

January 2001

Work performed by:

Lawrence Livermore National Laboratory

Westinghouse Savannah River Company

Argonne National Laboratory

Pacific Northwest National Laboratory

For the U.S. DOE MD Program

Plutonium Immobilization Project

Lawrence Livermore National Laboratory Livermore, California 94550 


\section{DISCLAIMER}

This document was prepared as an account of work sponsored by an agency of the United States Government. Neither the United States Government nor the University of California nor any of their employees, makes any warranty, express or implied, or assumes any legal liability or responsibility for the accuracy, completeness, or usefulness of any information, apparatus, product, or process disclosed, or represents that its use would not infringe privately owned rights. Reference herein to any specific commercial product, process, or service by trade name, trademark, manufacturer, or otherwise, does not necessarily constitute or imply its endorsement, recommendation, or favoring by the United States Government or the University of California. The views and opinions of authors expressed herein do not necessarily state or reflect those of the United States Government or the University of California, and shall not be used for advertising or product endorsement purposes.

Work performed under the auspices of the U.S. Department of Energy by Lawrence Livermore National Laboratory under Contract W-7405-ENG-48. 
Fissile Materials Disposition Program

\section{Plutonium Immobilization Project Development and Testing Baseline and Progress Monthly Report December 2000}

January 2001

Work performed by:

Lawrence Livermore National Laboratory Westinghouse Savannah River Company Argonne National Laboratory

Pacific Northwest National Laboratory

For the U.S. DOE MD Program

Plutonium Immobilization Project Lawrence Livermore National Laboratory Livermore, California 94550 
PIP-00-159 


\section{Table of Contents}

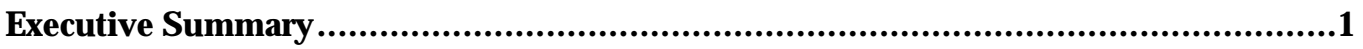

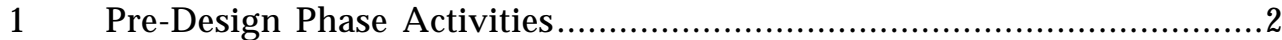

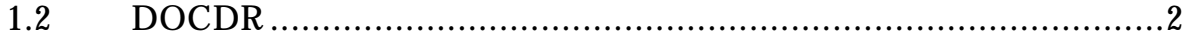

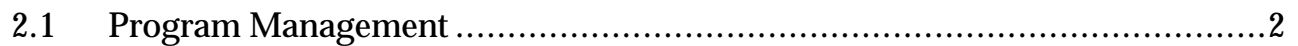

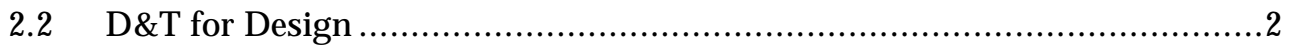

2.2.1 Technical Support and Integration ........................................

2.2.2 Immobilized Form Development .........................................2

2.2.3 Plutonium Conversion Process and Equipment Development..........2

2.2.4 First-Stage Immobilization Process and Equipment Development..3

2.2.5 Second-Stage Immobilization Process a nd Equi pment Development .3

$2.3 \quad$ D\&T for Form Qualification ....................................................

2.3.1 Form Performance Testing and Dissolution Modeling ....................

2.3.2 Thermodynamic Data Determination and Validation .................4

2.3.4 Form Qualification and Repository Interactions .........................

3 Technology Transfer ....................................................................

Report on Cost, Schedule, and Technical Progress ...............................................5

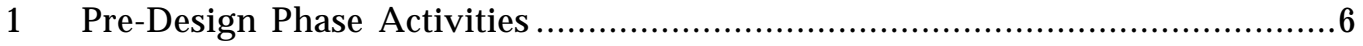

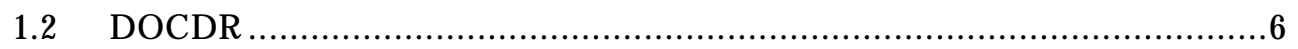

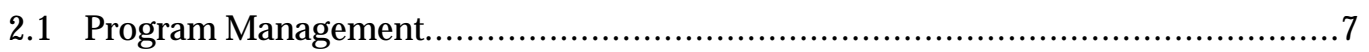

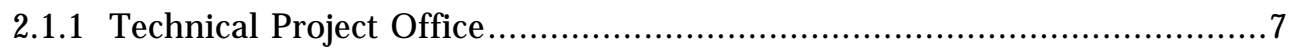

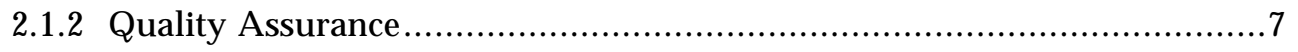

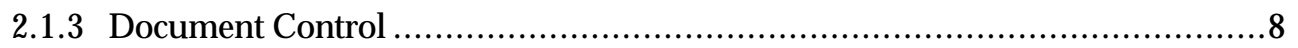

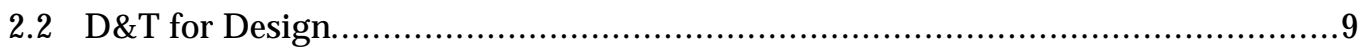

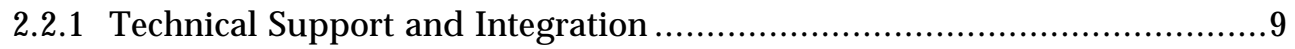

2.2.1.1 Feed Materials Characterization and Blending.........................9

2.2.1.2 Proliferation Resistance ........................................................ 10

2.2.1.3 Systems Integration and Cross-Cutting Functions....................... 10

2.2.1.4 Material Transport System.................................................. 11

2.2.1.5 Waste Handling System................................................. 12

2.2.2 Immobilized Form Development .................................................. 12

2.2.2.3 Process Control Model Development................................... 12

2.2.3 Plutonium Conversion Process and Equipment Development................... 13

2.2.3.1 Material Receipt and Storage ........................................... 13

2.2.3.3 Material Size Reduction.................................................. 14

2.2.3.4 Material Unpackaging and Sorting ...................................... 14

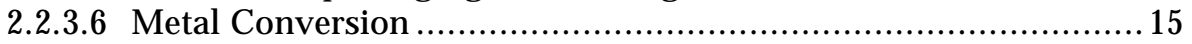

2.2.3.7 Impure Oxide Feed Preparation ........................................... 16

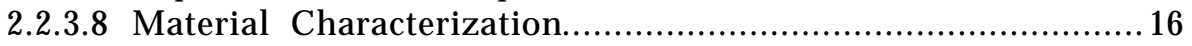

2.2.3.9 Material Control and Accountability ....................................17

2.2.3.10 In-Process Storage Vault................................................. 17

2.2.4 First Stage Immobilization Process and Equipment Development.............18

2.2.4.1 Ceramic Feed Blending and Batching ................................. 18 
2.2.4.2 Ceramic Process and Equipment Development and Testing ...........19

2.2.4.2.1 Ceramic Process Development................................... 19

2.2.4.2.2 Pu Ceramic Test Facility (PuCTF) ............................... 19

2.2.4.2.3 Ceramic Prototype Test Facility (CPTF) ..................... 20

2.2.4.3 Puck NDE/MC\&A for Process Control and SNM Accountability .. 22

2.2.4.4 Recycle of Unacceptable Materials .......................................22

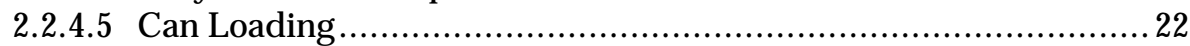

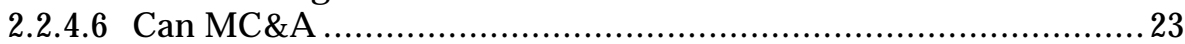

2.2.5 Second-Stage Immobilization Process and Equipment Development.........24

2.2.5.1 Can-In-Canister System.........................................................24

2.2.5.1.1 Can-In-Canister Design and Assembly ....................... 24

2.2.5.1.2 Canister Pour Analysis and Testing ............................ 25

2.2.5.1.3 Can/Magazine Storage Vault.................................... 25

2.2.5.2 Canister Transport System ............................................. 25

2.2.5.3 DWPF Receiving and Handling ....................................... 26

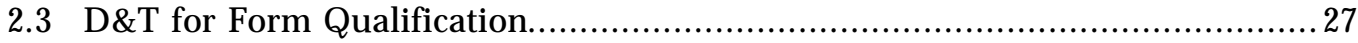

2.3.1 Form Performance Testing and Dissolution Modeling .........................22

2.3.1.1 Radiation-Damage Sample Synthesis and Characterization......27

2.3.1.2 Short-Term Corrosion Tests................................................. 28

2.3.1.3 Long-Term Corrosion Tests............................................... 29

2.3.1.4 Integrated Corrosion Tests............................................... 29

2.3.1.5 Single-Pass Flow-Through Tests ........................................ 31

2.3.1.6 Dissolution Model Development ....................................... 32

2.3.2 Thermodynamic Data Determination and Validation ..........................32

2.3.2.1 Aqueous Solubility/Speciation Measurement.........................32

2.3.2.2 Solid-Phase Enthalpy and Entropy Measurement.....................33

2.3.4 Form Qualification and Repository Interactions ................................ 33

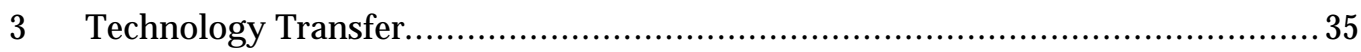

3.1 Preparation for Design Start: Site Operations Team ............................. 35

Appendix A1: FY00 AOP Milestones Status Summary for December.........................36

Appendix A2: FY01 AOP Milestones Status Summary for December........................ 43

Appendix B: December FY01 Cost Summary Report.............................................. 48 

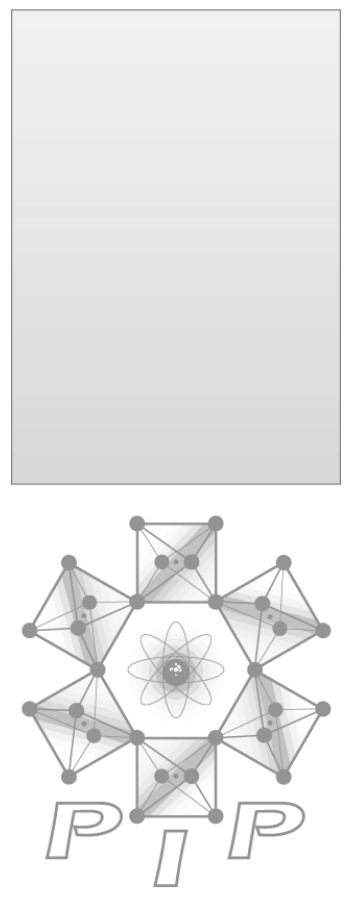

\section{Executive Summary}




\section{Pre-Design Phase Activities}

\subsection{DOCDR}

\section{Major Technical Accomplishments}

Bechtel prepared final documentation for their files associated with the D\&T program. The DOCDR, Rev. 3, is awaiting the final sign-off sheet from NN-62 prior to issuance.

\subsection{Program Management}

\section{Major Technical Accomplishments}

The TPO QA Office performed the first annual audit (PIP D\&T TPO Audit 0101) of the LLNL PIP QA Program.

\section{Significant Issues and Risks}

The budget reduction in FY01 will result in delay in the start of design and additional risk to the program.

\subsection{D\&T for Design}

\subsubsection{Technical Support and Integration}

Major Technical Accomplishments

- 14 SDDs for the 13 MT case were reviewed, updated, and prepared for issue.

- Resolution of RFETS materials-acceptance issues is near completion. WSRC is awaiting transmittal of item-level characterization data from RFETS.

\subsubsection{Immobilized Form Development}

Major Technical Accomplishments

A draft of the Preliminary PCM is nearly complete. Experimental testing in the Form Development activity is complete.

\subsubsection{Plutonium Conversion Process and Equipment Development}

\section{Major Technical Accomplishments}

- Completed a Facility Engineering Design Review (FEDR) for installation of the dustless transfer system and RIAR washer within Room 1378.

- Revisions of draft SDDs for Metal Conversion and Impure Oxide Feed Preparation will be completed by WSRC. 


\subsubsection{First-Stage Immobilization Process and Equipment Development}

\section{Major Technical Accomplishments}

- The installation of the PuCTF equipment in the Plutonium Facility has begun. The glovebox line in B-241 has been deactivated, and disassembly is well under way.

- A fully integrated furnace run using annular space cooling air, purge air, water cooling, and the exhaust gas system was performed at Clemson. A furnace cycle time of approximately 24 hours was observed which is consistent with the DOCDR assumptions.

- WSRC is in the process of contracting Cogema to perform blending studies with simulated PIP powders in an existing blender test bed.

\section{Significant Issues and Risks}

- The long cooling times observed from the earlier furnace testing at Clemson identified the sintering furnace as a potentially significant plant design issue. While recent results are encouraging, attention will continue to be focused on this issue.

\subsubsection{Second-Stage Immobilization Process and Equipment Development}

\section{Major Technical Accomplishments}

- The Phase 2 cold pour test report was issued.

- Revisions to the draft SDDs for the 13 MT throughput plant are underway.

\subsection{D\&T for Form Qualification}

\subsubsection{Form Performance Testing and Dissolution Modeling}

\section{Major Technical Accomplishments}

- Single-pass flow-through (SPFT) tests on a ${ }^{238} \mathrm{Pu}$-doped pyrochlore-rich composition at $\mathrm{pH}=2$ and $90^{\circ} \mathrm{C}$ indicate that the apparent dissolution rate of this material is $\sim 1,000 \mathrm{x}$ faster than the ${ }^{239} \mathrm{Pu}$-doped and 'cold' analogue material. It is not yet clear if these rates are valid (i.e., whether the increase in rate is due to radiation damage or some other effect). The ${ }^{238} \mathrm{Pu}$ sample now shows unambiguous evidence of radiation damage in $x$-ray diffraction measurements.

- Results from the SPFT tests $\left(\mathrm{pH}=2, \mathrm{~T}=90^{\circ} \mathrm{C}\right)$ with pyrochlore, pyrochlorerich, zirconolite, and brannerite materials indicate that dissolution rates of heavy-ion bombarded specimens are faster than the undamaged specimens. The largest effect is observed for the brannerite specimens, for which the ionbombarded specimen is dissolving at a $>10 \mathrm{x}$ higher rate than the undamaged brannerite specimen.

\section{Significant Issues and Risks}

We do not yet understand the reason for much higher SPFT dissolution rate measured on the ${ }^{238} \mathrm{Pu}$-bearing sample. 


\subsubsection{Thermodynamic Data Determination and Validation}

\section{Major Technical Accomplishments}

This task is complete.

\section{Significant Issues and Risks}

Reconnaissance experiments conducted at PNNL in late FY00 indicated that the solubility of Hf is strongly enhanced by the presence of carbonate. This behavior was totally unexpected, and could have important implications as to the mobility of $\mathrm{Hf}$ (the backup neutron absorber) under repository conditions. Our current plans and funding call for termination of this task in FY01. We will reassess the appropriateness of this plan and make a recommendation as to the continuation of this task when final budgets are available.

\subsubsection{Form Qualification and Repository Interactions}

\section{Major Technical Accomplishments}

No significant results to report.

\section{Significant Issues and Risks}

The roles and responsibilities of NN, EM, and RW remain unclear with respect to the "ownership" of the IPWF, and this continues to impede finalization of the Plutonium Immobilization Product Specifications (PIPS).

\section{Technology Transfer}

\section{Major Technical Accomplishments}

Planning for the combined independent design and technology review of the PIP program is underway. 


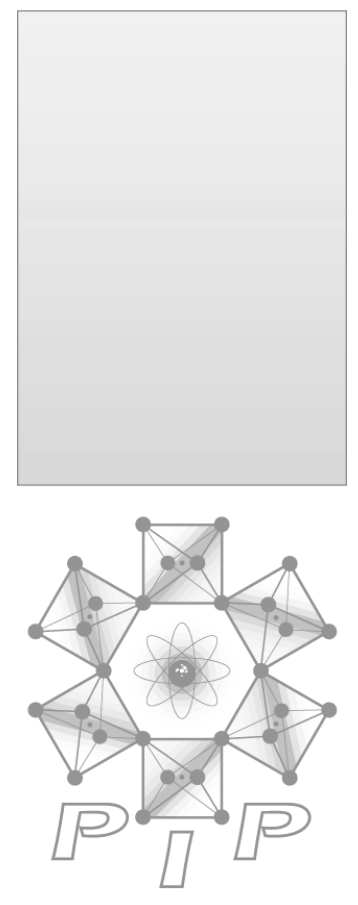

\section{Report on Cost, Schedule, and Technical Progress}




\section{$1 \quad$ Pre-Design Phase Activities}

\subsection{DOCDR}

Participants: LLNL and WSRC

Summary of Progress

DOCDR, Rev. 3, is awaiting final sign off sheet from NN-62.

\section{Cost Performance}

The LLNL variance of $-13 \%$ reflects the currently (July D\&T Plan) underestimated scope at LLNL for this effort in FY01. The task is complete with the incorporation of MD comments. A review copy of the DOCDR is with NN-62 awaiting signature.

\section{Schedule Performance}

The DOCDR effort is now complete except for receipt of the NN-62 sign off page and printing.

\section{Issues and Risks}

None. 
PIP-00-159

\subsection{Program Management}

\subsubsection{Technical Project Office}

Participants: LLNL, WSRC, ANL, and PNNL

\section{Summary of Progress}

- TPO has begun to evaluate optional planning cases in the event that the actual FY01 budget falls substantially short of the request.

- TPO and sites have begun responses to comments from NN-62 on the July 31, 2000 revision of the integrated D\&T plans.

\section{Cost Performance}

No significant cost variance.

\section{Schedule Performance}

No significant schedule variance.

\section{Issues and Risks}

The D\&T program is operating under budget authority that is substantially less than the budget allocation identified in the FY01 AOP. If additional funding is not provided in December, work on many tasks will have to cease, especially at LLNL.

\subsubsection{Quality Assurance}

Participants: LLNL, WSRC, ANL, and PNNL

\section{Summary of Progress}

\section{Technical Project Office}

The TPO QA Office performed the first annual audit (PIP D\&T TPO Audit 0101) of the LLNL PIP QA Program. One Corrective Action Report and three Observations were issued as a result of the audit.

\section{Project Participants}

Argonne National Laboratory (ANL) continued the revision of technical procedures to be in compliance with the revised ANL QA Plan.

Lawrence Livermore National Laboratory (LLNL) reviewed and updated LLNL PIP D\&T quality implementing procedures, logs and databases in preparation for the TPO audit. The PIP TPO D\&T QA Office performed the first annual audit (A01-01) of the LLNL QA Program. One Corrective Action Report (concerning inadequacies in the continuing implementation of QARD requirements in QA programs procedures and documents) and three Observations were issued as a result of the audit. 
Pacific Northwest National Laboratory (PNNL) performed the annual turnover of PIP QA records to the PNNL Records Center. A corrective actions response was submitted to the TPO QA Manager for the Corrective Action Report issued as a result of the TPO QA audit of the PNNL QA program, TPO QA Audit 0004 .

Westinghouse Savannah River Company (WSRC) issued three QA surveillances reports. These reports covered the Ceramic Prototype Test Facility, Measurement and Test Equipment for Immobilization Technology Section, and Laboratory Notebooks at CETL for CPTF task activities. Corrective action responses to the Observations noted in PIP D\&T TPO QA Audit 00-003 were finalized. A Software Quality Assurance Plan covering the life cycle development and use of the Plutonium Immobilization Project Furnace Data Acquisition System was developed.

\section{Cost Performance}

- PNNL had a variance of $-11 \%$ (under spent) for the QA task due to estimated cost for labor expense not being reported in the December timeframe as originally projected. This will not impact the overall budget for this task

- WSRC had a variance of $+120 \%$ (over spent) for the QA task due to an annual QA subcontract lien. The overrun will be reduced throughout the year as labor costs are collected against the lien.

- No significant cost variance for TPO, ANL or LLNL.

\section{Schedule Performance}

No significant schedule variance for any participant.

\section{Issues and Risks}

None.

\subsubsection{Document Control}

Participants: LLNL and WSRC

\section{Summary of Progress}

- The DCC updated the Master Report, which lists documents received by the DCC through October 2000 for inclusion in the annual report.

- The DCC annual report is awaiting issue.

\section{Cost Performance}

No significant cost variances.

\section{Schedule Performance}

Milestone 1.3a/FY00, Provide DCC annual report, scheduled for September 2000, will be completed in December. Limited resources and higher priorities have taken precedence over this report. The schedule for this report does not impact the overall schedule. 


\subsection{D\&T for Design}

\subsubsection{Technical Support and Integration}

\subsubsection{Feed Materials Characterization and Blending}

Participants: LLNL and WSRC

\section{Summary of Progress}

- LLNL responded to questions from NN-62 based on data in the classified draft of the RFETS feed streams evaluation, A Critical Analysis of the Rocky Flats Plutonium Inventory. Plans for finalizing the document, including a scheduled meeting for review by RF and WSRC personnel, were postponed due to the task leader's accident and subsequent unavailability.

- WSRC and DOE-EM jointly assisted NN-62 in identifying DOE weaponsgrade materials that are "committed" for transfer to Disposition (PDCF/MOX or PIP) to support the U.S.-Russian bilateral agreements. NN-62 was concerned that increased disposal to the Waste Isolation Pilot Plant could impact the U.S. commitment for 34 MT total, including at least 8.4 MT of weapons-grade material for feed to PIP. Initial study showed that sufficient material was available to allow NN-62 to concur in the EM decision to dispose Pu-bearing fluorides to WIPP.

- Final publication of the RFETS materials evaluation is expected for February. Further work on developing the Feed Materials Database, and preparation of the FY01 Feed Materials Report, was suspended. The suspension was due to transfer of the existing database from LLNL to SRS, transfer of item-level data from RFETS to SRS, and availability of the end-of-1999 DOE Nuclear Materials Inventory Assessment.

\section{Cost Performance}

- No significant cost variance at LLNL.

- WSRC was overspent by $15 \%(\$ 3,462)$ due to acceleration of $\mathrm{NN}-62$ support activity.

\section{Schedule Performance}

Due to the task leader's accident, Milestone 2.1/1/FY00, Revised draft of the feed materials characterization report, is on hold at least until February. Information from the draft will be provided on an as-needed basis to minimize schedule impacts.

\section{Issues and Risk}

- In order to perform critical planning studies, Pu materials data from disparate sources must be consolidated. These studies include an analysis of the impacts of different timings proposed for processing the inventories that are covered by, or not covered by, the U.S.-Russian agreement. These 
scenarios could affect equipment choices, operating plans, and even acceptance criteria.

- The reassessment of the RFETS data to evaluate the impact on Immobilization of the proposed RFETS consolidation program has stretched out the transition of this task to SRS from LLNL. This stretchout can be accommodated in FY01 with no impact to the A/E start date. However, the FY00 carryover will be needed to complete the task in FY01.

- PIP continues to work to confirm the quantities of plutonium that each site will transfer to MD for disposition. Major sites are still evaluating disposing some inventories to WIPP (instead of transfer to PIP), making it uncertain whether enough plutonium is firmly committed to MD to meet the strict requirements of the U.S.-Russian agreement. Decisions on MD-versus-WIPP disposition are on the critical paths for some EM stabilization plans, e.g., the RFETS closure plan, and decisions made at one site can affect MD's acceptance plans for other sites.

\subsubsection{Proliferation Resistance}

Participant: LLNL

\section{Summary of Progress}

Reviewed the National Academy of Science's report "The Spent-Fuel Standard for Disposition of Excess Weapon Plutonium: Application to Current DOE Options" for impact on PIP

\section{Cost and Schedule Performance}

The LLNL variance of $100 \%$ reflects the fact that the MD response to the NAS report has not yet been decided. It was anticipated in the July D\&T plan that the activity would begin in December.

\section{Schedule Performance}

A firm schedule for a study has not been established. The variance does not have an impact on the overall schedule at this time.

\section{Issues and Risk}

\$100K in budget for this task was provided to Task 2.3 (now 2.2.1.2) in late September. The funding arrived too late for use in FY00, but the carryover is needed in FY01 for the development of a response to the NAS report.

\subsubsection{Systems Integration and Cross-Cutting Functions}

Participants: LLNL and WSRC

\section{Summary of Progress}

- WSRC updated 14 draft SDDs and prepared them for issue to LLNL for review.

- WSRC and LLNL implemented a government assisted design (GAD) matrix with more than 30 design items to aid in preparing the SDDs and assigning design responsibility to the A-E and/or D\&T project. 
- The WSMS evaluation of shielding requirements for PIP, based on the 13 MT layout, is in progress. The evaluation is expected to be completed in February 2001.

- The WSRC Safeguards group has completed a preliminary vulnerability assessment and written a draft Security Requirements Identification (SRI) document. A security review was held with DWPF personnel to review the SRI as it applies to DWPF. The SRI has been approved by WSRC and DOESR. The contents of the SRI have been incorporated into an SDD-ready format, which will be held at SRS until the security posture for all PDP projects is established by DOE-NN.

\section{Cost Performance}

No significant cost variance.

\section{Schedule Performance}

The drafts of Technical Support SDDs (milestone 2.2.1.3/FY01/a) are in final editing and review. The edit and review process has required more effort than anticipated in August when the schedule was established. The SDDs are expected to be issued in February 2001. The later issue date is not expected to impact the overall design schedule.

Issues and Risk

None.

\subsubsection{Material Transport System}

Participant: WSRC

\section{Summary of Progress}

The draft SDD has been modified to reflect the scope change to a 13 MT throughput facility. Comments from LLNL have been incorporated in the final draft.

\section{Cost Performance}

No significant cost variance.

\section{Schedule Performance}

Milestone 2.2.1.4/FY01/a, Provide Draft SDD, was due 12/31/00. Completion of this milestone has been delayed to February 2001 due to limited resources available to complete the entire SDD package. The delay should not likely affect the overall project schedule because the two independent reviews and start of preliminary design will be delayed due to budget reductions announced in December.

Issues and Risk

None. 


\subsubsection{Waste Handling System}

Participant: WSRC

\section{Summary of Progress}

- The draft SDD has been modified to reflect the scope change to a $13 \mathrm{MT}$ throughput facility. Comments from LLNL have been incorporated in the final draft.

- The Waste Generation Report has been initiated. This report is scheduled to be completed in January 2001.

\section{Cost Performance}

This task is under spent by $\$ 3,364(24 \%)$ due to limited resource availability. This cost variance will not adversely impact the project.

\section{Schedule Performance}

- The draft SDD milestones will be delayed until February 2001 because of protraction of the edit and review process. This should affect the PIP project schedule.

- Milestone 2.2.1.5/FY01/a, Complete Waste Generation Report, was due in December 2000. This report will be delayed one month due to limited resource availability. The delay is not likely to affect the overall project schedule because the two independent reviews and start of preliminary design will be delayed due to budget reductions announced in December.

Issues and Risk

None.

\subsubsection{Immobilized Form Development}

\subsubsection{Process Control Model Development}

Participants: LLNL and WSRC

\section{Summary of Progress}

- A spreadsheet is being assembled as the basis for the preliminary Process Control Model. This spreadsheet includes as inputs the composition and isotopics of the plutonium oxide feed materials. The output is a calculation of the product composition, isotopics, phase assemblage, density, and pellet integrity. The spreadsheet also checks the feed impurity and processing specifications. (LLNL)

- Three of the forty full-scale Hf-Ce-Ce impurity compositions were examined using SEM/EDS. Results were transmitted to LLNL so that phase compositions could be compared with samples prepared with fewer impurities. (WSRC)

- A Form Development meeting was held at LLNL to review progress and to develop a path forward for future work to support the refinement of the 
PCM. A review of the statistical impurity testing indicated that dry processing was preferred for samples with high impurity contents. It appears that the larger the sum of the impurity (namely volatile impurity) and moisture content the more likely the pellet will crack during the firing cycle. A suggested list of tasks for the Process Development and NDE tasks was also generated for the remainder of FY01 and FY02. Experimental testing in the Form Development activity appears to be complete. (LLNL, WSRC)

\section{Cost Performance}

- No significant cost variance at LLNL.

- WSRC is under spent by $26 \%$ because data analysis activities associated with FY00 testing were delayed. The meeting held at LLNL in December will be used to direct FY01 work and it is expected that activities will ramp up. This will not impact overall schedule performance.

\section{Schedule Performance}

Milestone 2.2.2.3/FY01/a. Delivery of the "Preliminary Process Control Model" in March 2001 is on schedule.

\section{Issues and Risk}

The most precise SEM at SRS will be taken out of service to be installed in a glove box. In the long term this will benefit PIP, but access to the microscope will be limited until July 2001. (WSRC)

\subsubsection{Plutonium Conversion Process and Equipment Development}

\subsubsection{Material Receipt and Storage}

Participant: WSRC

\section{Summary of Progress}

The draft SDD has been modified to reflect the scope change to a 13 MT throughput.

\section{Cost Performance}

No significant cost variance.

\section{Schedule Performance}

Milestone 2.2.3.1/FY01/a, Provide Draft SDD, due 12/31/00, has been delayed to February 2001. The delay is not likely to affect the overall project schedule because the start of preliminary design will be delayed due to budget reductions announced in December.

\section{Issues and Risk}

None. 


\subsubsection{Material Size Reduction}

Participant: WSRC

\section{Summary of Progress}

WSRC recently was given the responsibility for development of the SDD for Material Size Reduction. This task will be initiated in January and will be completed in February 2001.

\section{Cost Performance}

This task was under spent by $\$ 7,500$ due to limited resource availability. This cost variance will not adversely impact the project.

\section{Schedule Performance}

Milestone 2.2.3.3/FY01/a, Provide Draft SDD, due 12/31/00, should be completed in February 2001. The delay, due to limited resource availability, should not affect the overall project schedule because start of preliminary design will be delayed due to budget reductions announced in December.

\section{Issues and Risk}

None.

\subsubsection{Material Unpackaging and Sorting}

Participants: WSRC and LLNL

\section{Summary of Progress}

- The draft SDD has been modified to reflect the scope change to a 13 MT throughput, and is undergoing review and editing.

- BNFL has submitted a response to the request for proposals to purchase a Dustless Oxide Transfer Device. The response indicates that they believe an off-the-shelf design will suffice and sent sketches for evaluation. BNFL has not yet provided a bid. The other two bidders have not yet responded to the request for proposals.

\section{Cost Performance}

This task was under spent by $\$ 4,409(16 \%)$ due to limited resource availability. This cost variance will not adversely impact the project.

\section{Schedule Performance}

Milestone 2.2.3.4/FY01/a, Provide Draft SDD, due 12/31/00, should be completed in February or March. The delay, due to limited resource availability, is not likely to affect the overall project schedule because the start of preliminary design will be delayed due to budget reductions announced in December.

\section{Issues and Risks}

None. 


\subsubsection{Metal Conversion}

Participants: LLNL and WSRC

\section{Summary of Progress}

- The metal conversion glove box was anchored to the floor in Room 1006. The glove box was aligned with the tunnel section extending from the East wall in Room 1006 to which it provides support.

- Work continued on assembling subsystems in the metal conversion glove box. Over $90 \%$ of the mechanical systems and pneumatic control line plumbing required for remote operations were completed.

- Cold tests of the oxidation system continued. A new frit design was tested and was judged to be satisfactory for the pulsed bed and pneumatic dustless transfer system. Tests began to determine the operating parameters and any design changes required on the halo blow back system used to keep the crucible flange clean.

- Installation began on the support systems for the glove box. The first instrumentation panel containing the hydrogen and oxygen sensors was installed in Room 1006.

\section{Cost Performance}

- This task is over spent at LLNL by $99 \%$, or $\$ 551,294$, because additional personnel had to be added to the metal conversion task starting in November. The budget forecast assumed there would be a slow-down in effort resulting from the Christmas and New Year's Holidays, but in actuality the team worked the majority of the month, taking a minimal amount of vacation time. Additionally, a WSRC lien for personnel was added to the LLNL budget. A further cost overrun is anticipated in January.

- This task is under spent at WSRC by $\$ 20,000$ due to limited resource availability. This cost variance will not adversely impact the project.

\section{Schedule Performance}

- For FY99 Milestone 5.6.a, the report Perform Feasibility Demonstrations on PuAl Alloys was written and is being reviewed.

- Milestone 2.2.3.6/FY01/a, Move System Into Radiation Material Management Area, has been completed. A summary report is undergoing review.

- Milestone 2.2.3.6/FY01/b, Provide Draft SDD, due 12/31/00, has been delayed until March 2001. This delay, due to limited resource availability, is not likely to affect the overall project schedule because the start of preliminary design will be delayed due to budget reductions announced in December.

\section{Issues and Risk}

The current success-oriented schedule does not include intangible issues such as DNFSB reviews of the Plutonium Facility. DOE Oakland representatives, members of the facility staff, and programmatic personnel reviewed the metal conversion schedule. The current schedule reflects our best planning based upon 
the remaining work, facility staff availability, and DOE Oakland review requirements.

\subsubsection{Impure Oxide Feed Preparation}

\section{Participant: LLNL}

\section{Summary of Progress}

- A Facility Engineering Design Review (FEDR) was completed for installation of the dustless transfer (DTU) unit and RIAR Washer in B332, Room 1378.

- Safety documentation required to bring both the DTU and the RIAR Washer into service are well underway.

- Major components for the DTU such as the motor, blower assembly, and pneumatic frits have been ordered.

\section{Cost Performance}

- No significant cost variance at LLNL.

- This task is under spent by $\$ 8,949$ at WSRC due to limited resource availability. This cost variance will not adversely impact the project.

\section{Schedule Performance}

- Milestone 5.7.1/FY00, Obtain and Install RIAR Salt Washer, is late because of a shortage of facility and programmatic support personnel. Completion of the milestone is currently seven months behind schedule. This should not impact availability of data for preliminary design because of the expected delay in PIP design start due to recently announced FY01 budget cuts.

- Milestone 2.2.3.7/FY01/a, Provide Draft SDD, due 12/31/00, will be delayed until February 2001. This delay, due to limited resource availability, is not likely to affect the overall project schedule because the start of preliminary design will be delayed due to budget reductions announced in December.

\section{Issues and Risk}

Facility personnel are still reviewing the seismic safety note and the USQ

Screening. Further delays to the schedule are expected.

\subsubsection{Material Characterization}

Participants: LLNL and WSRC

\section{Summary of Progress}

- The repaired fume hood arrived from Lab Fabricators on December 11th in excellent condition.

- Plant Engineering personnel completed moving the fume hood into B332, Room 1006 and seismically anchoring it to the floor.

- Facility staff completed approval of the USQ Determination to penetrate the exterior wall of Room 1006 for an argon gas line. 
- A USQ Screening addressing the addition of all the material characterization support equipment (fume hood, ventilation ducts, and HEPA housings) to Room 1006 has been drafted.

\section{Cost Performance}

- This task is over spent at LLNL by $17 \%$, or $\$ 26,985$, because of manpower expenses incurred as a result of higher than expected installation costs posted in late December. The overage should dissipate after the installation of the fume hood is completed in February.

- This task is under spent at WSRC by $\$ 8,974$ (17\%). Material Characterization is a level of effort task supporting LLNL activities. The cost variance has no impact on project deliverables.

\section{Schedule Performance}

No significant schedule variance.

\section{Issues and Risk}

None.

\subsubsection{Material Control and Accountability}

Participant: WSRC

\section{Summary of Progress}

The MC\&A draft SDD has been modified to reflect the scope change to a 13 MT throughput facility. Comments from LLNL have been incorporated in the final draft.

\section{Cost Performance}

No significant cost variance.

\section{Schedule Performance}

Issue of the draft SDD, due 12/00, has been delayed to February 2001 as a consequence of a protracted review and edit schedule.

\section{Issues and Risk}

None.

\subsubsection{In-Process Storage Vault}

Participant: WSRC

\section{Summary of Progress}

The draft SDD has been modified to reflect the scope change to a $13 \mathrm{MT}$ throughput. Comments from LLNL have been received and incorporated in the final draft.

\section{Cost Performance}

No significant cost variance. 


\section{Schedule Performance}

Milestone 2.2.3.10/FY01/a, Provide Draft SDD, due 12/31/00, has been delayed to February 2001. This delay, due to limited resource availability, is not likely to affect the overall project schedule because the start of preliminary design will be delayed due to budget reductions announced in December.

\section{Issues and Risk}

None.

\subsubsection{First-Stage Immobilization Process and Equipment Development}

\subsubsection{Ceramic Feed Blending and Batching}

Participant: WSRC

\section{Summary of Progress}

WSRC is in the process of contracting COGEMA to perform blending studies with simulated PIP powders in an existing blender. These tests will include verifying a powder metering system. WSRC modified the procurement package to include the blender test plan, obtained approvals, and submitted the package to SRS Procurement where it is currently under review.

\section{Cost Performance}

This task is under spent by $\$ 44,726$ (48\%) due to the delays in placing the blender test procurement.

\section{Schedule Performance}

- Milestone 2.2.4.1/FY01/a, Provide Draft SDD, due 12/31/00, has been delayed to February 2001. This delay, due to limited resource availability, is not likely to affect the overall project schedule because the start of preliminary design will be delayed due to budget reductions announced in December.

- Milestone 2.2.4.1/FY01/b, Complete Blender Test at Vendor, will not be met due to delays in placing the order and the time required by COGEMA to prepare for the tests. The delay should not affect data for PIP design because of the expected delay in design start due to FY01 budget cuts.

\section{Issues and Risk}

The blender procurement will be delayed to FY02 if funding is not available. 


\subsubsection{Ceramic Process and Equipment Development and Testing}

\subsection{Ceramic Process Development}

Participant: LLNL

\section{Summary of Progress}

- A meeting with the form development team was held in December to discuss the results to date regarding impurity testing with full-scale $\mathrm{Hf} / \mathrm{Ce} / \mathrm{U}$ and $\mathrm{Hf} / \mathrm{Ce} / \mathrm{Ce}$ pucks at LLNL. Additional tests to be performed were identified. These tests are being performed in conjunction with the impurity limit testing being performed at WSRC and will assist in verification of the impurity limits for the process. In addition to the composition variations, processing conditions related to pressing and sintering are also being investigated for their effects on the final product.

- Limited binder burnout testing is being performed on the pucks containing impurities to determine the effect of the binder burnout temperature on the puck integrity.

\section{Cost Performance}

A cost variance of 51\% (about \$30k) occurred due to employees charging the wrong account. These charges are being reapplied to the correct account.

\section{Schedule Performance}

Activities are proceeding on schedule for winding up the process development activities.

\section{Issues and Risk}

The biggest unknown in the process development area is the plant-sintering schedule. Work is proceeding at LLNL with the binder burnout furnace and at Clemson with the plant-prototypical furnace to resolve this issue.

\subsection{Pu Ceramic Test Facility (PuCTF)}

Participants: LLNL and WSRC

\section{Summary of Progress}

- The moving and installation of the PuCTF began. The furnace box and press were the first subsystems to be installed. The furnace box was broken down into two box sections for shipping and clearance through the doorways. The puck handling robot was left installed, but blocked in a secure position. A template to locate the press bolt holes on the floor plates was made and aligned. The predrilled holes permitted an immediate method of seismically anchoring the press. After press installation, the Granulator glovebox was brought into the room and restrained with temporary seismic hold-downs. This box was brought in three pieces: top hat, main box section and the stand.

- The remainder of the PuCTF (excepting the Control System which is undergoing final programming and check out) in B-241 was disassembled and is ready for moving and installation. The attritor heads were removed from 
the stands and the stands removed from the box. The buckets remain in the box and are securely blocked.

- Integration of the Supervisory Control System network communications continues. Some difficulties remain in using Modbus protocol to communicate with the Attritor PLC., and with the RS Linx protocol to communicate with the Granulator Allen Bradley PLC. It is anticipated the Modbus problem will be overcome before the Attritors are powered down for disassembly the $2^{\text {nd }}$ week in January. It is believed that an upgrade of RS Linx and RS Logic software will overcome the Allen Bradley communications problem. Hopper Transport robot programming was modified: (1) to provide a means of moving both hoppers off their respective scales so that they may be calibration manually and (2) to provide the capability to park the robot actuators in a convenient location during shutdown to provide for expeditious homing on startup. Instrumentation and Control (I\&C) documentation continues. I \& $C$ drawings have been completed for all except the Hopper Transport.

\section{Cost Performance}

- No significant cost variance at LLNL.

- This task is under spent by $\$ 20,061$ (19\%) at WSRC. This task is a level of effort supporting LLNL activities.

\section{Schedule Performance}

No significant schedule variance.

\section{Issues and Risk}

Accomplishing work on a timely basis in The Plutonium Facility remains a concern as demonstrated by the longer than anticipated time it took to complete the room preparation.

\subsection{Ceramic Prototype Test Facility (CPTF)}

Participants: WSRC and Clemson

\section{Summary of Progress}

- A fully integrated furnace run using annular space cooling air, purge air, water cooling, and the exhaust gas system was performed. The furnace run used $5 \mathrm{scfm}$ of purge air during binder burnout and during cool down. As a consequence, the furnace cycle time was reduced from approximately 46 hours to 24 hours. The heavy, four-wall trays used in the test showed no structural problems (these trays have now completed four sintering cycles with no apparent degradation). During the test, however, half of the trays of pucks did not completely sinter. The cause of this under sintering is being evaluated. Work is underway to finish evaluating the results of the test data and to plan the next furnace run.

- Clemson Environmental Technologies Laboratory (CETL) has responded to the Scope of Work Statement for the design, fabrication, and construction services for the CPTF. The Scope of Work outlines facility modifications/additions necessary to install full-scale equipment associated with first stage immobilization. It is anticipated that DOE-SR will release the 
funding for the contract in January and the construction firm will be brought on board shortly thereafter.

- The delivery for the HSA-20 attritor is on schedule for February.

- The specifications for the CPTF tumble granulator have been issued for vendor response. It is anticipated that a response will be received in January, and the anticipated delivery date is the summer of 2001.

- The contract for the 15 ton press has been awarded and assembly drawings will be supplied at the beginning of January. A meeting of the press team will be held after the drawings are received and then a subset of the team will meet with the vendor to discuss any changes/comments. An additional procurement for upgrades to the press, including the dust control system and direct feed modification, has been transmitted to CETL.

- The four wall trays purchased in FY99 have high side walls so that reticulated zirconia ceramic plates could be installed to inhibit chemical interaction with the pucks. Evaluations are being performed to see if the overall stack height can be reduced by approximately 3 inches if a zirconia thermal spray coating is used instead of the reticulated ceramic.

- The Task Technical and QA Plan for the CPTF has been updated to reflect the changes in scope and personnel roles and responsibilities and is currently being reviewed. Included in the changes are the controls to be used for experiments to support repository qualification and the plant design (FDD and SDD).

- The Software Quality Assurance Plan for the Clemson Furnace Data Acquisition System was issued.

\section{Cost Performance}

This task is under spent by $19 \%$ because the team is awaiting the awarding of the CPTF construction contract to CETL. Once the contract is awarded it is expected that efforts will increase significantly. Additionally, several CPTF team members took more vacation time over the holidays than originally forecasted. These variances will not impact the task schedule or deliverables.

\section{Schedule Performance}

No significant schedule variance.

\section{Issues and Risk}

- Furnace cycle time continues to be the biggest area of risk. However, recent test results are encouraging. Attempts are being made to optimize the furnace heating/cooling rate with consideration for the furnace components, sintering furniture, and pucks. Testing in the CPTF prototype furnace will continue to provide insight into the parameters affecting the furnace cycle time, including whether puck integrity is the limiting factor.

- Changes to the existing furnace tray configuration could impact the overall CPTF schedule if the design of the tray stacker is affected. 


\subsubsection{Puck NDE/MC\&A for Process Control and SNM Accountability}

Participants: LLNL and WSRC

\section{Summary of Progress}

The prototype x-ray diffraction system was received at WSRC and installation of the equipment in the SRTC lab has commenced.

\section{Cost Performance}

- There are no significant cost variances at LLNL.

- This task is under spent by $13 \%$ at WSRC because the prototype system installation is deferring major analytical work until January. An increase in effort is expected in January and subsequent months when testing commences with the prototype system. This will not impact the task schedule or deliverables.

\section{Schedule Performance}

The delay in NDE glovebox activation in the LLNL Pu facility should not delay the completion of the validation milestone.

\section{Issues and Risk}

None.

\subsubsection{Recycle of Unacceptable Materials}

\section{Participant: LLNL}

\section{Summary of Progress}

This task will be subsumed by Task 2.2.4.2.

\section{Cost Performance}

No significant cost variance.

\section{Schedule Performance}

No significant schedule variance.

Issues and Risk

None.

\subsubsection{Can Loading}

Participant: WSRC

\section{Summary of Progress}

- WSRC completed the draft SDD for Can Loading, revision E. The document is being routed for signatures. 
- WSRC completed the 13 MT can loading computer simulation. The simulation shows the can loading robot working with two bagless transfer units as well as the latest can inspection concept.

\section{Cost Performance}

No significant cost variance.

\section{Schedule Performance}

Milestone 2.2.4.5/FY01/a, Provide Draft SDD, due 12/31/00, has been delayed to February 2001. This delay, due to limited resources, is not likely to affect the overall project schedule because the start of preliminary design will be delayed due to budget reductions announced in December.

\section{Issues and Risk}

None.

\subsubsection{Can MC\&A}

Participant: WSRC

\section{Summary of Progress}

- The MC\&A draft SDD has been modified to reflect the scope change to a 13 MT throughput facility. Comments from LLNL have been incorporated in the final draft.

- Baseline testing for the calorimetry system continues.

\section{Cost Performance}

This task is under spent by $\$ 12,196$ (63\%) due to limited resource availability. This cost variance will not adversely impact the project.

\section{Schedule Performance}

Issue of the draft SDD has been delayed to February 2001 due to limited resources. This delay should not affect the overall project schedule.

\section{Issues and Risk}

None. 


\subsubsection{Second-Stage Immobilization Process and Equipment Development}

\subsubsection{Can-in-Canister System}

\subsection{Can-in-Canister Design and Assembly}

Participant: WSRC

\section{Summary of Progress}

- All Phase 2 cold pour canisters have been filled with glass. The low pour rate and instrumented canisters have been cut and analyzed. The results of the analysis have been documented in the Phase 2 cold pour test report.

- One of the two proliferation canisters contained a known weld defect in the top head weld that was not repaired prior to pouring with glass; the plan being to rework the weld after the glass had been poured. A nonconformance report (NCR) was written and the rework of the defect has been completed. Another minor weld defect (underfill) was discovered during the analysis of the first one and a second NCR was issued to disposition that defect. Both NCRs have been closed and the affected proliferation canister has been returned to CETL for storage.

- The Can-In-Canister System Design Description was revised for the 13MT throughput of the Plutonium Immobilization Plant and was issued for comment. Comments have been dispositioned and Revision E of the system design description will be issued.

- The canister loading arm has been delivered to the site. The vendor provided assistance in setting up the arm in Building 305-A. Although there are no funds available to perform any developmental testing with the arm, there is funding to have the arm moved from its current storage location in Building 305-A to Building 773-50A. A contract has been let to enable the arm's original supplier to assist with preparing the loading arm for operation in its new location.

\section{Cost Performance}

No cost schedule variance.

\section{Schedule Performance}

Milestone 2.2.5.1.1/FY01/a, Provide Draft SDD, due 12/31/00, has been delayed to February 2001. This delay, due to limited resources, is not likely to affect the overall project schedule because the start of preliminary design will be delayed due to budget reductions announced in December.

\section{Issues and Risk}

None. 


\subsection{Canister Pour Analysis and Testing}

Participants: LLNL and WSRC

\section{Summary of Progress}

- The Phase 2 Cold Pour Test report was issued, satisfying the 12/31/00 milestone, Complete Phase 2 Cold Pour Test Report.

- Work continued on the Cold Pour Test Task File. Most of the required documents have been filed. This Task File will be used mainly to provide Phase 2 test quality assurance documentation.

- The top weld on the second proliferation canister filled during the Phase 2 Test was approved by SRS Receipt and Inspection personnel.

\section{Cost Performance}

This task is under spent by $\$ 38,374$ (35\%) due to anticipated undercharge from SCUREF. This cost variance will be corrected next month and will not adversely impact the project.

\section{Schedule Performance}

No significant schedule variance.

\section{Issues and Risk}

None.

\subsection{Can/Magazine Storage Vault}

Participant: WSRC

\section{Summary of Progress}

The Can/Magazine Storage Vault information in the Can-In-Canister SDD was revised for the 13MT throughput of the Plutonium Immobilization Plant.

\section{Cost Performance}

No significant cost variance.

\section{Schedule Performance}

No significant schedule variance.

\section{Issues and Risk}

None.

\subsubsection{Canister Transport System}

Participant: WSRC

Summary of Progress

The draft SDD has been modified to reflect the scope change to a 13 MT throughput. 


\section{Cost Performance}

No significant cost variance.

\section{Schedule Performance}

Issue of the draft SDD will be delayed to February 2001 due to resource

limitations. No significant impact to the PIP design schedule is anticipated.

Issues and Risk

None.

\subsubsection{DWPF Receipt and Handling}

Participant: WSRC

\section{Summary of Progress}

The draft SDD for DWPF Receiving and Handling was revised to reflect the 13MT throughput of the Plutonium Immobilization Plant.

\section{Cost Performance}

No significant cost variance.

\section{Schedule Performance}

Issue of the draft SDD will be delayed to February 2001 due to resource limitations. No significant impact to the PIP design schedule is anticipated.

\section{Issues and Risk}

None. 
PIP-00-159

\subsection{D\&T for Form Qualification}

\subsubsection{Form Performance Testing and Dissolution Modeling}

\subsubsection{Radiation-Damage Sample Synthesis and Characterization}

Participant: PNNL

\section{Summary of Progress}

- Analyses of the XRD results are nearly complete for the specimens that have been stored at room temperature. These results indicate that pyrochlore is susceptible to radiation damage. The diffraction peaks from these specimens show substantial broadening for the pyrochlore phase and a change from the cubic pyrochlore phase to the cubic fluorite phase. Damage also occurs to the zirconolite phase, but the damage does not appear to be as severe;

diffraction peaks remain relatively sharp and unit cell parameters appear to remain constant with increasing damage (up to one year). There is a build-up of an amorphous phase that cannot be identified. However, this may be the result of the transformation of zirconolite to pyrochlore or the disappearance of the brannerite phase that was present in the original phase assemblage. Some fluorite $(<10 \%)$ is also evident in the XRD for the zirconolite-bearing specimens.

- The large peaks in the XRD from zirconolite-rich baseline ceramics that were observed in the diffraction from specimens stored at $250^{\circ} \mathrm{C}$ were observed in a zirconolite-rich baseline specimen that had been stored at room temperature. These diffraction peaks were not reproducible even in the same specimen. We have made the initial conclusion that the intensity of these peaks is due to misalignment of the specimen in the diffraction beam. To remedy the alignment problem, we have developed an alignment tool to make the alignment easier.

- We have no specific test for friability in these specimens. This evaluation is left until the end of the test period when we examine the specimens for microcracking. However, circumstantial evidence suggests that the specimens are more friable than when they were first made. When preparing the specimens for the PUF and SPFT, we had a difficult time obtaining particles of the correct size distribution. The grinding techniques that had been used previously resulted in a very fine particle distribution and size reduction occurred much more easily than previously.

- In the short-term static dissolution test $\left(\mathrm{MCC}-1,90^{\circ} \mathrm{C}, 3 \mathrm{~d}\right)$, the amounts of $\mathrm{Pu}$ found in solution are greater than those found during the initial characterization of the same specimens 1 year ago. The amounts released range from $0.05 \mathrm{~g} / \mathrm{m}^{2}$ for the ${ }^{238} \mathrm{Pu}$-bearing, phase-pure pyrochlore to $0.6 \mathrm{~g} / \mathrm{m}^{2}$ for the ${ }^{238} \mathrm{Pu}$ zirconolite-rich baseline. During the initial characterization of these specimens 1 year ago, the amounts of $\mathrm{Pu}$ released ranged from $1 \times 10^{-5} \mathrm{~g} / \mathrm{m}^{2}$ for coarse ${ }^{238} \mathrm{Pu}$ zirconolite to $0.02 \mathrm{~g} / \mathrm{m}^{2}$ for the ${ }^{238} \mathrm{Pu}$ pyrochlorerich and ${ }^{238} \mathrm{Pu}$ zirconolite-rich baseline ceramics. The analyses for the other constituents are continuing. 


\section{Cost Performance}

This task is overspent by $12 \%$. This is due to unanticipated machine work that was needed for the specimen storage vessels and XRD specimen alignment tools.

\section{Schedule Performance}

We are on schedule for the milestone 2.3.1.1/FY01/a (a letter report on the results from the characterization and testing of the radiation damage specimens).

\section{Issues and Risk}

None.

\subsubsection{Short-Term Corrosion Tests}

Participant: ANL

\section{Summary of Progress}

- A series of MCC-1 tests with the baseline (A0) ceramics were initiated and terminated in August. The tests were conducted at $90^{\circ} \mathrm{C}$ in deionized water for 1, 3, 5, 7 and 42 days using PDA-Teflon vessels. The $\mathrm{pH}$ values of the test leachates and blanks are between 5 and 6 . Solutions from these tests are being analyzed; results are expected in early January.

- Planning continued for starting the fabrication of samples for TCLP testing. A safety review is being finalized, and a task plan has been completed.

\section{Cost Performance}

This task is overspent by $73 \%(\$ 24.2 \mathrm{~K})$. This is due to front end loading of this task at the beginning of the year. Once the TCLP tests have been completed, very little effort will be spent on short-term testing. Therefore, this will not impact the overall budget for this task this year.

\section{Schedule Performance}

There has been a delay in initiating the planned TCLP tests due to the need to conduct new safety analyses in the laboratory where the samples will be fabricated. Because of this, it is likely that the associated milestone (2.3.1.2/FY01/a, Document results of TCLP tests) will be 1 to 2 months late. This should have no significant effect on the overall project schedule.

\section{Issues and Risk}

Two measurements required in the fabrication of the TCLP samples cannot currently be completed with the appropriate QA pedigree. The dimensions of both green and sintered ceramic pellets cannot be made until a set of calipers is calibrated and verified. Calipers have been sent to a QA-qualified vendor for calibration. The calcining and sintering temperature cannot be reported until the furnace is calibrated with a NIST-traceable thermocouple. An approved vendor in the Chicago area is fabricating a NIST-traceable thermocouple. 


\subsubsection{Long-Term Corrosion Tests}

Participant: ANL

\section{Summary of Progress}

- A 182-day PCT-B test with the A0-LLNL ceramic, scheduled for termination in October, was terminated in November. Leachant and strip samples have been submitted for metals analysis; transmission electron microscopy analysis of the colloids sample has begun. Data from this test will be compared to data from the 98-day test with the same ceramic and to data from tests with the B3-13 impurity-bearing ceramic.

- A 728-day PCT-B test with A0-ANL will be terminated in January. Data from this test will be compared to data from previous tests with the same ceramic to describe reaction progress. The reacted ceramic will be examined to determine whether the brannerite is being preferentially dissolved. Preferential dissolution of brannerite was observed during the reaction of a zirconolite-rich ceramic, and was thought to lead to increased release of $\mathrm{Gd}$ and $\mathrm{Pu}$ from that ceramic.

\section{Cost Performance}

No significant cost variance.

\section{Schedule Performance}

Work is on schedule for delivery of milestone 2.3.1.3/FY01/a, Document results of long-term testing of ceramic.

\section{Issues and Risk}

None.

\subsubsection{Integrated Corrosion Tests}

Participants: ANL and PNNL

\section{Summary of Progress}

- The long-term unsaturated "drip" tests with the Hf-Pu-U baseline ceramic were scheduled to be sampled during August, but has been delayed due to laboratory modifications. We will sample the tests in January. Solution analyses will include $\mathrm{pH}$ and cation concentrations. Colloid analyses will include sequential filtration, dynamic light scattering, and TEM. Solids analyses will include SEM and TEM of the reacted particles. (ANL)

- A set of long-term unsaturated "drip" tests with the Hf-Pu-U impurity (B313) ceramic will be initiated when material becomes available from LLNL. A task plan has been written and approved. The data from these tests will be compared to data from tests with the A0 ceramic. These data will allow us to evaluate how the presence of impurities and silicate phases in the ceramic affects their corrosion behavior. (ANL)

- A series of $200^{\circ} \mathrm{C}$ vapor hydration tests with the B3-13 impurity ceramic will also be initiated when the material is available. Data from these tests will be compared to data from similar tests with the A0 ceramic. These data will 
allow us to evaluate how the presence of impurities and silicate phases in the ceramic affects their corrosion in these high temperature tests. The B3-13 ceramic contains an amorphous silicate phase in intimate contact with the titanate phases. Therefore, the results of a vapor hydration test with this material will be interpreted in terms of reactions between the silicate phase and the titanate phases. (ANL)

- A new oven has been designed and built in the testing glovebox. The completion of this oven will allow us to move the unsaturated drip tests into the glovebox. The oven is complete and is currently being tested. A revised safety review and QA documentation are being prepared. (ANL)

- The two PUF columns for the last Integrated Corrosion Tests were returned from an external site with precision machine milled seal surfaces. The columns passed pressure tests and were loaded with ceramic and glass. Test startup will occur shortly. (PNNL)

\section{Cost Performance}

- Spending for this task is $24 \%$ ( $\$ 25.7 \mathrm{~K})$ lower than planned at ANL. This is due to a smaller than anticipated effort being spent on this task this month. This will not impact the overall budget for this task this year.

- This task is overspent by $20 \%$ at PNNL. This is due to the spending on this task occurring at a higher rate for the first quarter in order to accomplish scope from FY00. Two PUF tests were started with the intent of allowing the tests to run without any extensive data collection other than those collected with the computer. Following the first quarter, spending is expected to decrease commensurate with the maintenance level of the experiments. The FY01 spend plan will be adjusted to support the revised rate of spending noted above.

\section{Schedule Performance}

- Work is on schedule for the ongoing drip tests at ANL for milestone 2.3.1.4/FY01/b, Issue report on status of drip tests; however, initiation of new vapor hydration and drip tests has been delayed due to the inability to ship Pu-bearing samples from LLNL to ANL because of a lack of approved shipping containers. This will limit the amount of information in the milestone report.

- We are a couple of months behind schedule for the start of the test with ${ }^{238} \mathrm{Pu}$ pyrochlore baseline ceramic, but the preliminary report (milestone 2.3.1.4/FY01/b) is on schedule. The duration of the tests reported on in this report, however, will be shorter than planned.

\section{Issues and Risk}

Ceramic material is needed from LLNL to initiate new vapor hydration and unsaturated drip tests. (ANL) 


\subsubsection{Single-Pass Flow-Through Tests}

Participants: LLNL, ANL, and PNNL

\section{Summary of Progress}

- Testing is continuing on the ${ }^{238} \mathrm{Pu}$-doped pyrochlore-rich composition at $\mathrm{pH}=$ 2 and $90^{\circ} \mathrm{C}$. So far, the apparent dissolution rate of this material is $\sim 1,000 \mathrm{X}$ faster than the ${ }^{239} \mathrm{Pu}$-doped and 'cold' analogue material, but it is not yet clear if these rates are valid. (PNNL)

- Dissolution experiments with ${ }^{239} \mathrm{Pu}$-doped pyrochlore and pyrochlore-rich materials over the $\mathrm{pH}$ interval $2-10$ at $90^{\circ} \mathrm{C}$ are running. No unusual dissolution behavior has been observed so far. (PNNL)

- Results from the SPFT experiments $\left(\mathrm{pH}=2, \mathrm{~T}=90^{\circ} \mathrm{C}\right)$ with pyrochlore, pyrochlore-rich, zirconolite, and brannerite materials indicate that dissolution rates of heavy-ion bombarded specimens are faster compared to the undamaged specimens. The largest effect is observed for the brannerite specimens, wherein the ion-bombarded specimen is dissolving at $>10 \mathrm{X}$ higher rate than the undamaged brannerite specimen.

- Dissolution experiments with non-radioactive pyrochlore and pyrochlore-rich materials over the $\mathrm{pH}$ interval $2-10$ at $90^{\circ} \mathrm{C}$ are complete. Dissolution of both materials exhibit a $\mathrm{pH}$-dependence with the minimum near $\mathrm{pH}=8$.

- A new TEM analyst has examined samples from two of the SPFT ceramics. Although images were collected, the resolution of the CCD camera is inadequate; multibeam GIF images are needed to obtain the high-resolution images needed to see alteration layers. Training of the new analyst on the operation of the GIF has been delayed. (ANL)

- All the remaining SPFT tests have been shut down and all archived samples sent in for analysis. Reacted solids will be archived for future analysis. (LLNL)

\section{Cost Performance}

- Support for the examination of the SPFT samples at ANL is not directly funded. Effort spent on this work is being taken from the long-term and integrated testing tasks. (ANL)

- There are no significant cost or performance variations to report at PNNL.

- This task is $11 \%$ overspent at LLNL. This is due to a heavy load of analyses associated with the shutdown of the SPFT experiments. The spending rate will decrease in the future.

\section{Schedule Performance}

- PNNL is on schedule to deliver milestone 2.3.1.5/FY01/a, Update the repository data package with results from the SPFT on radiation damage specimens and LLNL tests.

- A draft of the FY00 milestone FY00/4.1.2, Update SPFT report with results from longer-term testing, is complete, and is undergoing internal review. This 
report was delayed due to illness and unplanned leave by personnel funded under this task in FY00.

Issues and Risk

None.

\subsubsection{Dissolution Model Development}

Participant: LLNL

\section{Summary of Progress}

The second interim modeling report will be completed by the end of January.

\section{Cost Performance}

No significant cost variance.

\section{Schedule Performance}

The FY00 milestone FY00/4.1.4, Issue final report on model development for repository $P A$, continues. This report was delayed due to illness and unplanned leave by personnel funded under this task in FY00. The report is now expected to be completed by January 2001

\section{Issues and Risk}

None.

\subsubsection{Thermodynamic Data Determination and Validation}

\subsubsection{Aqueous Solubility/Speciation Measurements}

Participants: LLNL and PNNL

\section{Summary of Progress}

There is no new work planned in this task for FY01. The only ongoing activities relate to the completion of two FY00 milestones, and the transfer of notebooks and records to QA and the records center.

\section{Cost Performance}

No costs to report. Closeout costs for this task are included in the costs for the Form Qualification and Repository Interactions Task.

\section{Schedule Performance}

This task is complete

\section{Issues and Risks}

Reconnaisance experiments conducted at PNNL in late FY00 indicated that the solubility of Hf is strongly enhanced by the presence of carbonate. This behavior was totally unexpected, and could have important implications as to the mobility of $\mathrm{Hf}$ (the backup neutron absorber) under repository conditions. Our current plans and funding call for termination of this task in FY01. We will 
reassess the appropriateness of this plan and make a recommendation as to the continuation of this task when final budgets are available. RW has been informed of these results and is looking into the potential impact on their analyses. Because Hf has been proposed as the primary neutron absorber for waste packages containing some DOE spent fuels, this result may have implications that extend beyond the $\mathrm{Pu}$ Immobilization Program.

\subsubsection{Solid-Phase Enthalpy and Entropy Measurements}

Participants: LLNL, UC Davis, and BYU

\section{Summary of Progress}

This task is complete.

\subsubsection{Form Qualification and Repository Interactions}

Participants: LLNL, WSRC, ANL, and PNNL

\section{Summary of Progress}

- A review on repository qualification was held at SRS with DOE EM and DOE RW personnel in December. The meeting included general discussions on DWPF issues as well as a review of the Pu Immobilization Program. DOE RW reiterated that their comments on the Plutonium Immobilization Product Specifications (PIPS) were for information only and they do not intend to perform a formal review. There was little discussion on programmatic issue regarding the ownership of the Immobilized Plutonium Waste Form (IPWF). It is unlikely that this issue will be resolved in the near term, thus, the PIPS will be issued as is after minor editorial corrections are made.

- Minor refinement of the draft Plutonium Immobilization Compliance Plan (PICP) continues at a low level of effort.

\section{Cost Performance}

- This task is under spent by 33\% at SRS because personnel working on this task are primarily working on SDD updates

- This task is under spent by $11 \%$ at PNNL. The spend plan for this task is level loaded throughout the year. A variance has occurred this month as staff addressed needs in other programs. This will not impact the overall budget for this task this year.

- This task is under spent by $22 \%$ at ANL. The spend plan for this task is level loaded throughout the year. A variance has occurred this month as staff addressed needs in other programs. This will not impact the overall budget for this task this year.

- Spending for this task is $76 \%(\$ 48 \mathrm{~K})$ over the planned budget at LLNL. The additional costs reflect the continuation of FY00 workscope into FY01. (Completion of reports for WBS 4.2, and closeout of those tasks.) We have requested that we be allowed to use our uncommitted FY00 carryover to cover these costs. 


\section{Schedule Performance}

The PIPS will be transmitted to DOE with comment resolution annotations in January. Completion of this milestone has been delayed due to difficulties in obtaining comments.

\section{Issues and Risks}

The major risk to the qualification program is the delay in issuing the PIPS and the ownership definition for the IPWF. 


\section{Technology Transfer}

\subsection{Preparation for Design Start: Site Operations Team}

Participant: WSRC

\section{Summary of Progress}

Activity associated with preparation of design start has been terminated due to budget reductions announced in December. This activity will be delayed as the design start date is rescheduled.

\section{Cost Performance}

This task is under spent by $\$ 2,159$ (43\%) due to its termination.

\section{Schedule Performance}

This task will be delayed as the design start date is rescheduled.

\section{Issues and Risk}

Budget reductions will delay the start of design and associated activities. 
PIP-00-159

Appendix A1: FY00 AOP Milestones Status Summary for December 2000 


\begin{tabular}{|c|c|c|c|c|c|c|c|c|c|c|}
\hline WB: & Task & & Milestones & $\begin{array}{l}\text { Resp. } \\
\text { Site }\end{array}$ & $\begin{array}{l}\text { Due } \\
\text { Date }\end{array}$ & $\begin{array}{l}\text { Anticipate } \\
\text { d Comp } \\
\text { Date }\end{array}$ & $\begin{array}{c}\% \\
\text { Comp }\end{array}$ & $\begin{array}{l}\text { Draft } \\
\text { Report } \\
\text { Complete }\end{array}$ & $\begin{array}{l}\text { Final } \\
\text { Report } \\
\text { Complete }\end{array}$ & Status/ Comments \\
\hline 1.0 & $\begin{array}{l}\text { Proaram Manaaement } \\
\text { FY99 Milestones }\end{array}$ & & & & & & & & & \\
\hline 1.1 & Proiect Office & a & Provide revised intearated D\&T plan & LLNL & Nov-99 & & 100 & & Mar-00 & PIP-00-035 \\
\hline 1.2 & OA & $\begin{array}{l}\text { a. } \\
\text { b. }\end{array}$ & $\begin{array}{l}\text { Complete manaqement assessment rpt } \\
\text { Complete annual audit }\end{array}$ & $\begin{array}{l}\text { LLNL } \\
\text { LLNL }\end{array}$ & $\begin{array}{l}\text { Sep-00 } \\
\text { Sep-00 }\end{array}$ & $\begin{array}{l}\text { Sep-00 } \\
\text { Sep-00 }\end{array}$ & $\begin{array}{l}100 \\
100\end{array}$ & & $\begin{array}{l}\text { Sep-00 } \\
\text { Sep-00 }\end{array}$ & $\begin{array}{l}\text { PIP } 00-117 \text { LTR } \\
\text { PIP } 00-115 \text { LTR }\end{array}$ \\
\hline 1.3 & Document Control & $a$ & Provide DCC annual report & LLNL & Sep-00 & Dec-00 & 100 & & 12-Dec & PIP-00-154 \\
\hline 2.1 & $\begin{array}{l}\text { Feed Materials Definition and } \\
\text { Characterization } \\
\text { FY99 Milestones }\end{array}$ & b. & $\begin{array}{l}\text { Update the feed materials } \\
\text { rharacterization report }\end{array}$ & LLNL & Feb-99 & & 100 & & $11 / 4 / 99$ & PIP $\quad 99-148$ \\
\hline 2.1 & $\begin{array}{l}\text { Feed Materials Characterization and } \\
\text { Rlending }\end{array}$ & a. & $\begin{array}{l}\text { Update feed materials blending strategy } \\
\text { report }\end{array}$ & LLNL & Mar-99 & & 100 & & $12 / 8 / 99$ & PIP $\quad 99-170$ \\
\hline & & & $\begin{array}{l}\text { Complete cost-benefit analysis for } \\
\text { samplinn plan }\end{array}$ & LLNL & Sep-99 & & 100 & $1 / 30 / 00$ & $6 / 30 / 00$ & PIP $\quad 00-002$ \\
\hline & & & $\begin{array}{l}\text { Update the feed materials } \\
\text { characterization report }\end{array}$ & LLNL & Sep-99 & & 100 & & $11 / 4 / 99$ & PIP $\quad 99-148$ \\
\hline 2.4 & Material Transport System & a. & Complete material transport system plan & WSRC & Sep-99 & & 100 & $1 / 31 / 00$ & $7 / 28 / 00$ & PIP $\quad 00-092$ LTR \\
\hline 2.1 & $\begin{array}{l}\text { Feed Materials Characterization and } \\
\text { Blending }\end{array}$ & 1 & $\begin{array}{l}\text { Revised draft of the feed materials } \\
\text { characterization report }\end{array}$ & LLNL & May-00 & $10 / 27 / 00$ & 75 & Jul-00 & Feb-01 & $\begin{array}{l}\text { Milestone will be assessment of RFETS } \\
\text { inventory and is on hold pending L. Gray } \\
\text { return. }\end{array}$ \\
\hline 2.3 & Technical Intearation & & Draft Facilitv Desian Description & LLNL & Jul-00 & & 100 & Jul- 00 & $7 / 21 / 00$ & PIP $\quad 00-067$ LTR \\
\hline & & & Draft System Design Description for & WSRC & Jul-00 & 30-Sep & 100 & & $9 / 15 / 00$ & PIP $\quad 00-092 / P I P \quad 00-056$ LTR \\
\hline & & & $\begin{array}{l}\text { Material Transport } \\
\text { Waste Handlina practices evaluation }\end{array}$ & WSRC & Mar-00 & & 100 & $2 / 30 / 00$ & $3 / 30 / 00$ & PIP $\quad 00-091$ \\
\hline & & & $\begin{array}{l}\text { Draft System Design Description for } \\
\text { Waste Handlinn }\end{array}$ & WSRC & Apr-00 & $09 / 30 / 00$ & 100 & 30-Sep & $9 / 15 / 00$ & PIP $\quad 00-057$ LTR \\
\hline
\end{tabular}




\begin{tabular}{|c|c|c|c|c|c|c|c|c|c|c|c|}
\hline WB: & Task & Milestones & $\begin{array}{l}\text { Resp. } \\
\text { Site }\end{array}$ & $\begin{array}{l}\text { Due } \\
\text { Date }\end{array}$ & $\begin{array}{c}\text { Anticipate } \\
\text { d Comp } \\
\text { Date }\end{array}$ & $\begin{array}{c}\% \\
\operatorname{comp}\end{array}$ & $\begin{array}{c}\text { Draft } \\
\text { Report } \\
\text { Complete }\end{array}$ & $\begin{array}{c}\text { Final } \\
\text { Report } \\
\text { Complete }\end{array}$ & & Status/ & Comments \\
\hline \multicolumn{12}{|c|}{$\begin{array}{c}\text { 3.0 Immobilized Form Development } \\
\text { FYg9 Milestones }\end{array}$} \\
\hline \multirow[t]{3}{*}{3.4} & Process Control Model Development & a. Provide interim data summary report & $\begin{array}{l}\text { LLNL\& } \\
\text { ANSTO }\end{array}$ & Jul-99 & 06/30/00 & 100 & & $7 / 20 / 00$ & PIP & 00-094 & \\
\hline & & $\begin{array}{l}\text { b. 1. Complete equilibrium phase diagram } \\
\text { and 2. inpurity studies sample }\end{array}$ & $\begin{array}{l}\text { LLNL\& } \\
\text { ANSTO }\end{array}$ & Sep-99 & $03 / 15 / 00$ & 100 & & $2 / 16 / 00$ & PIP & 00-016 & \\
\hline & FY00 Milestones & & & & & & & & & & \\
\hline 3.1 & $\begin{array}{l}\text { Basic Formulation and Process } \\
\text { Parameters? }\end{array}$ & 1 Provide formualtion update for the SDD & LLNL & Dec-99 & $08 / 31 / 00$ & 100 & & $11 / 20 / 00$ & PIP & 00-141 & \\
\hline 3.3 & Product Control Model Development & $\begin{array}{l}1 \text { Provide PCM methodology for preliminary } \\
\text { testinn }\end{array}$ & LLNL & Dec-99 & $02 / 29 / 00$ & 100 & & $2 / 28 / 00$ & PIP & 00-036 & \\
\hline
\end{tabular}




\begin{tabular}{|c|c|c|c|c|c|c|c|c|c|}
\hline WB: & Task & Milestones & $\begin{array}{l}\text { Resp. } \\
\text { Site }\end{array}$ & $\begin{array}{l}\text { Due } \\
\text { Date }\end{array}$ & $\begin{array}{c}\text { Anticipate } \\
\text { d Comp } \\
\text { Date }\end{array}$ & $\begin{array}{c}\% \\
\operatorname{Comp}\end{array}$ & $\begin{array}{c}\text { Draft } \\
\text { Report } \\
\text { Complete }\end{array}$ & $\begin{array}{c}\text { Final } \\
\text { Report } \\
\text { Complete }\end{array}$ & Status/ Comments \\
\hline \multirow[t]{2}{*}{4.0} & Performance Testing \& Qua & ification for Repository & & & & & & & \\
\hline & FY99 Milestones & & & & & & & & \\
\hline \multirow[t]{2}{*}{4.1} & $\begin{array}{l}\text { Form Performance Testing \& } \\
\text { Dissolutition Mndelina }\end{array}$ & $\begin{array}{l}\text { e. Issue data package on SPFT results for } \\
\text { repnsitorv license application }\end{array}$ & LLNL & Jun-99 & & 100 & & $1 / 19 / 00$ & PIP $\quad 00-003$ \\
\hline & & $\begin{array}{l}\text { f. Issue interim report on model } \\
\text { development for repository license } \\
\text { applicationn }\end{array}$ & LLNL & Jun-99 & & 100 & & $1 / 19 / 00$ & PIP $\quad 00-003$ \\
\hline \multirow[t]{2}{*}{4.3} & $\begin{array}{l}\text { Form Qualification and Repository } \\
\text { Interactions }\end{array}$ & b. Issue Rev0 of PIPS & WSRC & Aug-99 & & 100 & & $1 / 19 / 00$ & PIP 00-004 \\
\hline & FY00 Milestones & & & & & & & & \\
\hline \multirow[t]{6}{*}{4.1} & $\begin{array}{l}\text { Form Performance Testing \& } \\
\text { nisconlutionn Mndelind }\end{array}$ & $\begin{array}{l}1 \text { Document baseline characteristics of } \\
\text { 238P॥ reramir samples }\end{array}$ & PNNL & Apr-00 & $06 / 30 / 00$ & 100 & $5 / 1 / 00$ & $6 / 2 / 00$ & PIP $\quad 00-081$ \\
\hline & & $\begin{array}{l}2 \text { Update SPFT report with results from } \\
\text { Innner-term tectinn }\end{array}$ & LLNL & May-00 & $02 / 01 / 01$ & 99 & $8 / 10 / 00$ & & Manuscript in final review \\
\hline & & $\begin{array}{l}3 \text { Document results of short-term testing } \\
\text { of the reramir. }\end{array}$ & ANL & Jun-00 & $06 / 30 / 00$ & 100 & $5 / 8 / 00$ & $6 / 30 / 00$ & PIP-00-096 \\
\hline & & $\begin{array}{l}4 \text { Issue final report on model development } \\
\text { fnr repnsitnry PA }\end{array}$ & LLNL & Jun-00 & $02 / 01 / 01$ & 95 & & & Manuscript in review \\
\hline & & $\begin{array}{l}5 \text { Document results of long-term testing } \\
\text { nf the reramir. }\end{array}$ & ANL & Aug-00 & $09 / 29 / 00$ & 100 & $8 / 16 / 00$ & Sep-00 & PIP $\quad 00-120$ LTR $\quad 11 / 11 / 00$ \\
\hline & & $\begin{array}{l}7 \text { Letter report on status of 238PU } \\
\text { radiation damace effecits }\end{array}$ & PNNL & Sep-00 & $09 / 01 / 00$ & 100 & $8 / 15 / 00$ & $9 / 15 / 00$ & PIP $\quad 00-110 L T R$ \\
\hline \multirow[t]{4}{*}{4.2} & $\begin{array}{l}\text { Thermodynamic Data Determination } \\
\text { and Validation }\end{array}$ & & & & & & & & \\
\hline & & $\begin{array}{l}2 \text { Issue final report on Ti solubility and } \\
\text { speriatinn }\end{array}$ & LLNL & Aug-00 & $10 / 15 / 00$ & 100 & $10 / 30 / 00$ & $11 / 22 / 00$ & PIP-00-148 \\
\hline & & $\begin{array}{l}3 \text { Issue final report on } \mathrm{Hf} \text { solubility and } \\
\text { speciatinn }\end{array}$ & PNNL & Aug-00 & $08 / 10 / 00$ & 100 & $8 / 20 / 00$ & $9 / 15 / 00$ & PIP $\quad 00-108$ \\
\hline & & $\begin{array}{l}4 \text { Issue report on Pu and Gd sorption on } \\
\text { r.nllhids }\end{array}$ & LLNL & Aug-00 & $10 / 20 / 00$ & 100 & $10 / 15 / 00$ & $11 / 30 / 00$ & PIP-00-156 \\
\hline \multirow[t]{2}{*}{4.3} & $\begin{array}{l}\text { Form Qualifications and Repository } \\
\text { Interactions }\end{array}$ & 1 Provide initial draft of PICP & WSRC & Sep-00 & $10 / 20 / 00$ & 100 & $11 / 21 / 00$ & $11 / 21 / 00$ & PIP-00-149 \\
\hline & & $\begin{array}{l}2 \text { Issue integrated data report for } \\
\text { reposnitorv lirensina application }\end{array}$ & LLNL & Aug-00 & $10 / 31 / 00$ & 100 & $1 / 31 / 01$ & $1 / 25 / 01$ & PIP-01-004 \\
\hline
\end{tabular}




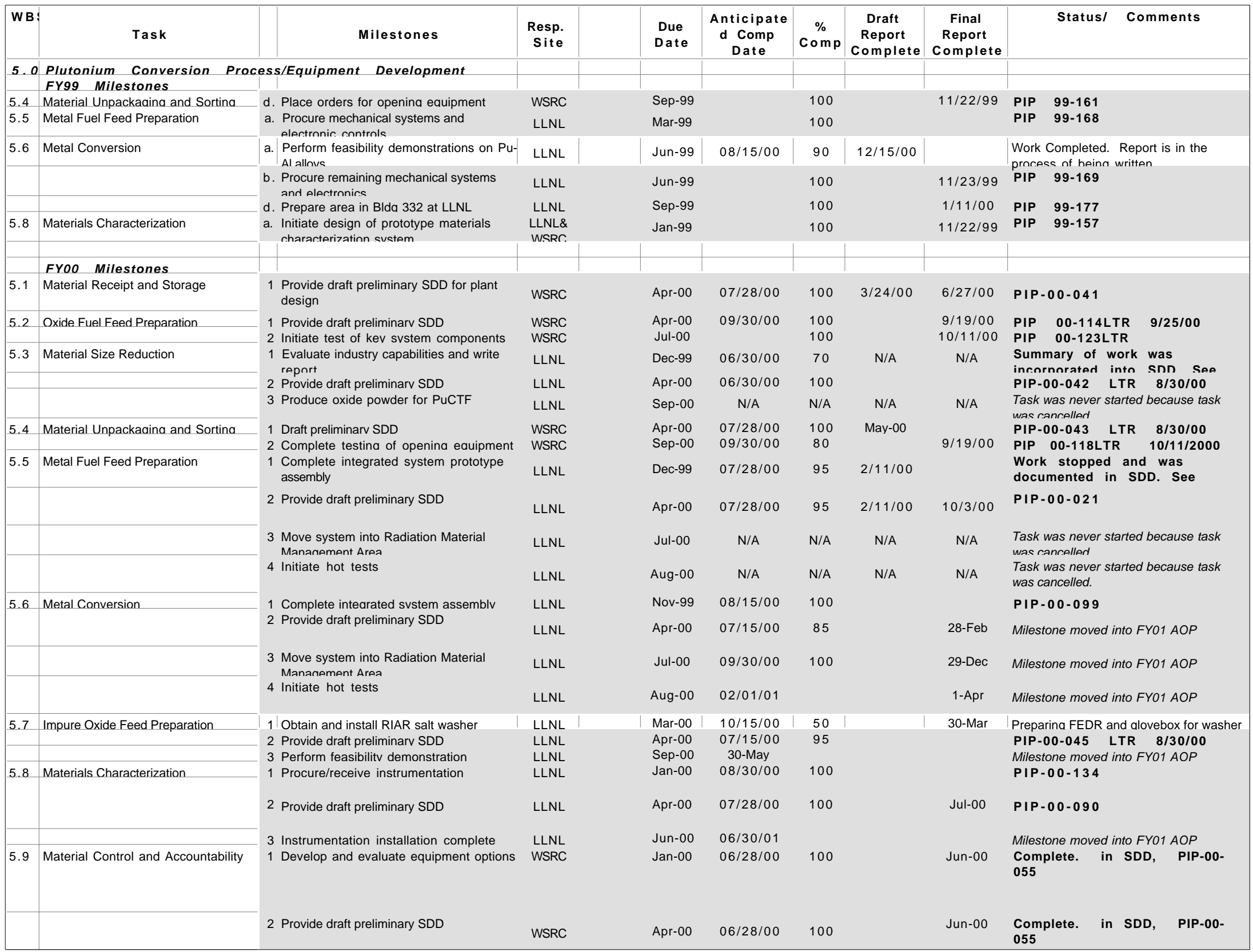




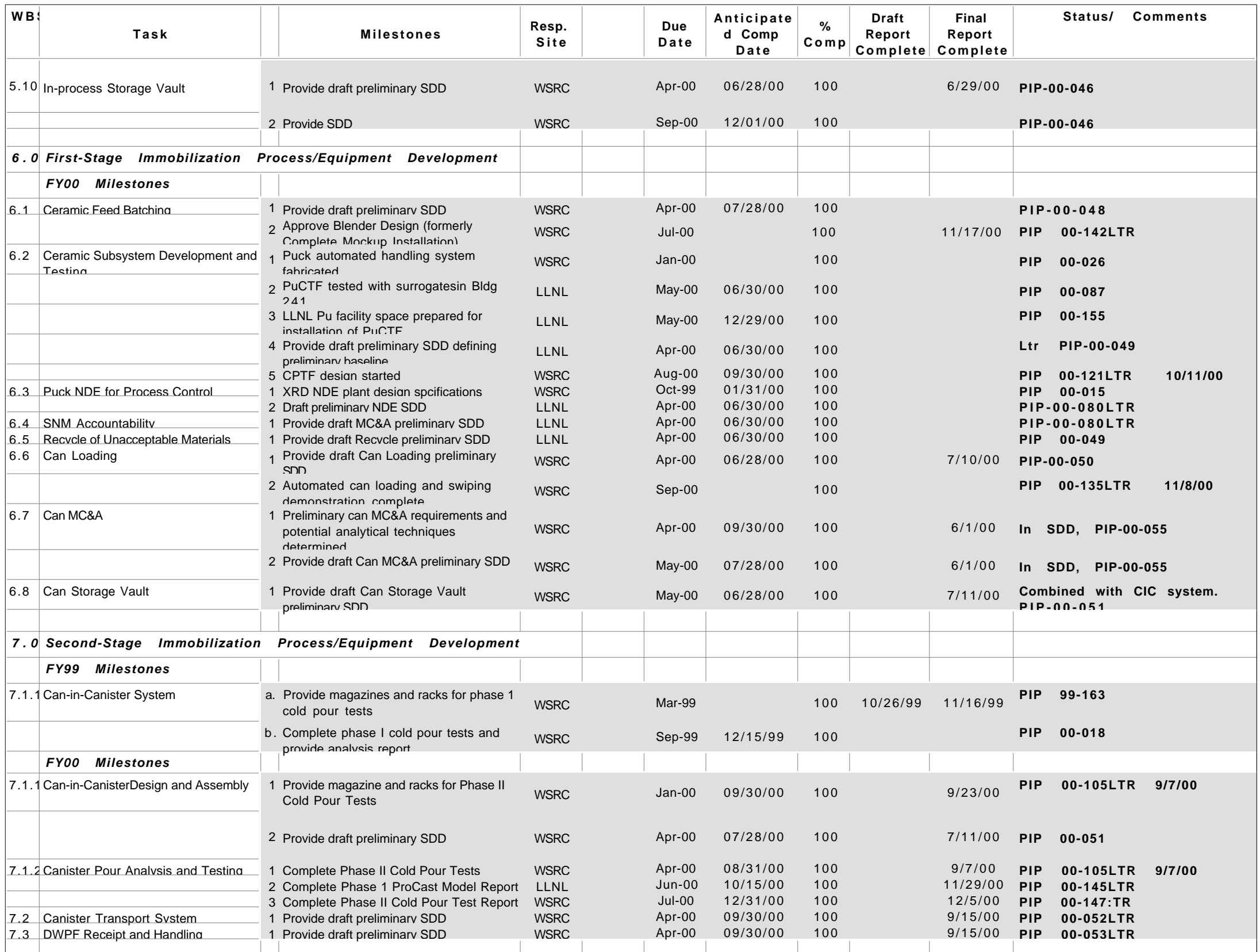




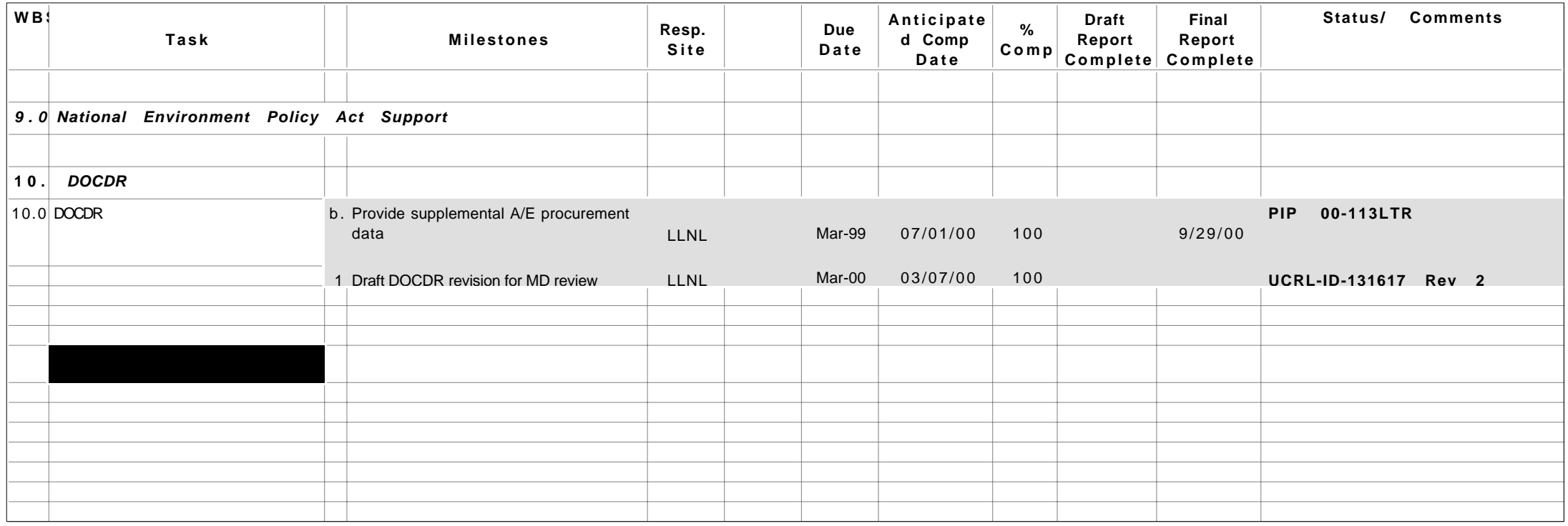


Appendix A2: FY01 AOP Milestones Status Summary for December 2000 


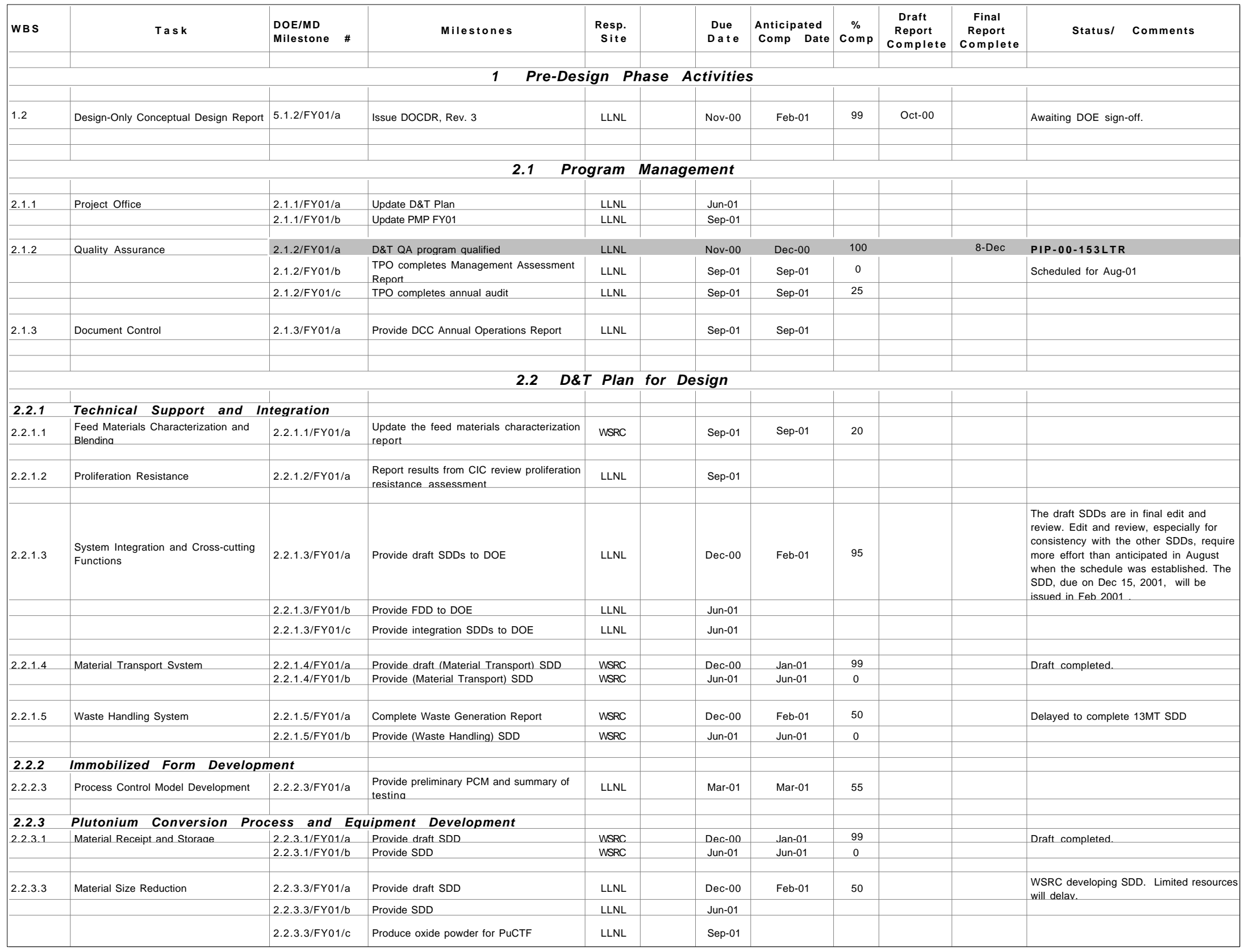




\begin{tabular}{|c|c|c|c|c|c|c|c|c|c|c|}
\hline WBS & Task & $\begin{array}{l}\text { DOE/MD } \\
\text { Milestone \# }\end{array}$ & Milestones & $\begin{array}{l}\text { Resp. } \\
\text { Site }\end{array}$ & $\begin{array}{l}\text { Due } \\
\text { Date }\end{array}$ & $\begin{array}{l}\text { Anticipated } \\
\text { Comp Date }\end{array}$ & $\begin{array}{c}\% \\
\text { comp }\end{array}$ & $\begin{array}{c}\text { Draft } \\
\text { Report } \\
\text { Complete }\end{array}$ & $\begin{array}{c}\text { Final } \\
\text { Report } \\
\text { Complete }\end{array}$ & Status/ Comments \\
\hline \multirow{2}{*}{ 2.2.3.4 } & Material Unpackaging and Sorting & 2.2.3.4/FY01/a & Provide draft SDD & WSRC & Dec-00 & Jan-01 & 95 & & & Draft completed. \\
\hline & & 2.2.3.4/FY01/b & Complete concept for material transfer & WSRC & Mar-01 & Sep-01 & 0 & & & Delayed due to budget cut. \\
\hline \multirow{4}{*}{ 2.2.3.6 } & Metal Conversion & 2.2.3.6/FY01/a & Move system into RMMA & LLNL & Oct- 00 & $12 / 30 / 00$ & 100 & & 29-Dec & PIP-00-152 \\
\hline & & 2.2.3.6/FY01/b & Provide draft SDD & LLNL & Dec-00 & $28-\mathrm{Feb}$ & 85 & & & Preliminary draft in preparation \\
\hline & & 2.2.3.6/FY01/c & Initiate hot tests & LLNL & Jun-01 & 14-Jun & & & & $\begin{array}{l}\text { Hardware is in Pu building. Cold activation } \\
\text { is underway }\end{array}$ \\
\hline & & 2.2.3.6/FY01/d & Complete initial hot tests & LLNL & Jul-01 & $7 / 31 / 01$ & & & & \\
\hline \multirow[t]{3}{*}{ 2.2.3.7 } & Impure Oxide Feed Preparation & 2.2.3.7/FY01/a & Provide draft SDD & LLNL & Dec-00 & Feb-01 & 80 & & & $\begin{array}{l}\text { WSRC developing SDD. Limited resources } \\
\text { will delav. }\end{array}$ \\
\hline & & 2.2.3.7/FY01/b & Perform feasibility demonstration & LLNL & Feb-01 & 30-May & & & & $\begin{array}{l}\text { Material received from Hanford. Awaiting } \\
\text { installation of washer in Pu building. }\end{array}$ \\
\hline & & 2.2.3.7/FY01/c & Provide SDD & LLNL & Jun-01 & & & & & \\
\hline \multirow[t]{2}{*}{ 2.2.3.8 } & Materials Characterization & 2.2.3.8/FY01/a & Complete installation of equipment & $\begin{array}{l}\text { LLNL \& } \\
\text { WSRC }\end{array}$ & Dec-00 & $06 / 30 / 01$ & & & & $\begin{array}{l}\text { Lost several months because of } \\
\text { difficulities obtaining facility approvals, } \\
\text { labor, and ISM issues with outside } \\
\text { vendors }\end{array}$ \\
\hline & & 2.2.3.8/FY01/b & Provide input to Analytical SDD & LLNL & Apr-01 & & & & & \\
\hline 2.2.3.9 & Material Control and Accountability & 2.2.3.9/FY01/a & Provide input to MC\&A SDD & WSAC & Apr-01 & Apr-01 & 0 & & & \\
\hline \multirow[t]{2}{*}{ 2.2.3.10 } & In-process Storage Vault & 2.2.3.10/FY01/a & Provide draft SDD & WSRC & Dec-00 & Jan-01 & 99 & & & Draft completed. \\
\hline & & $2.2 .3 .10 / \mathrm{FY} 01 / \mathrm{b}$ & Provide SDD & WSRC & Jun-01 & Jun-01 & 0 & & & \\
\hline & First-Stage Immobilization & Process and & Equipment Development & & & & & & & \\
\hline \multirow{3}{*}{$\begin{array}{l}2.2 .4 \\
2.2 .4 .1\end{array}$} & Ceramic Feed Blending and Batching & $2.2 .4 .1 / \mathrm{FY} 01 / \mathrm{a}$ & Provide draft blending SDD & WSRC & Dec-00 & Jan-01 & 95 & & & Draft completed. \\
\hline & & 2.2.4.1/FY01/b & Complete blender test at vendor & WSRC & Mar-01 & Mar-02 & 10 & & & Postponed due to budget cut. \\
\hline & & 2.2.4.1/FY01/c & Provide blending SDD & WSRC & Jun-01 & Mar-02 & 0 & & & Postponed due to budget cut. \\
\hline \multirow[t]{2}{*}{ 2.2.4.2.1 } & Ceramic Process Development & 2.2.4.2.1/FY01/a & $\begin{array}{l}\text { Provide draft SDD for ceramification } \\
\text { system }\end{array}$ & LLNL & Dec-00 & 28-Feb-01 & 80 & & & In progress. \\
\hline & & 2.2.4.2.1/FY01/b & Provide SDD, Rev. 0 & LLNL & Jul-01 & & & & & Deferred to FY 02. \\
\hline \multirow[t]{3}{*}{ 2.2.4.2.2 } & Plutonium Ceramic Test Facility (PuCTF) & 2.2.4.2.2/FY01/a & $\begin{array}{l}\text { PuCTF installation complete in LLNL Pu } \\
\text { facility }\end{array}$ & LLNL & Feb-01 & 28-Feb-01 & 50 & & & Installation started. \\
\hline & & 2.2.4.2.2/FY01/b & PuCTF operational with plutonium & LLNL & Jun-01 & 22-Aug-01 & 0 & & & $\begin{array}{l}\text { Dependent on installation completion and } \\
\text { ORR approval bv LLNL and/or DOE }\end{array}$ \\
\hline & & 2.2.4.2.2/FY01/c & PUCTF operation validated with plutonium & LLNL & Sep-01 & 2-Oct-01 & 0 & & & \\
\hline 2.2.4.2.3 & $\begin{array}{l}\text { Ceramification Prototype Test Facility } \\
\text { (CPTF) }\end{array}$ & 2.2.4.2.3/FY01/a & CPTF design completed & WSRC & Dec-00 & $01 / 15 / 00$ & $99 \%$ & & & $\begin{array}{l}\text { Report completed and sent to TPO for } \\
\text { formal issue to DOE-MD. }\end{array}$ \\
\hline \multirow[t]{2}{*}{ 2.2.4.3 } & $\begin{array}{l}\text { Puck NDE/MC\&A for Process Control } \\
\text { and SNM Accountability }\end{array}$ & 2.2.4.3/FY01/a & $\begin{array}{l}\text { WSRC NDE XRD plant prototype test } \\
\text { system installed }\end{array}$ & WSRC & Jan-01 & $01 / 31 / 01$ & 80 & & & $\begin{array}{l}\text { XRD unit received and moved into } \\
\text { laboratory in SRTC. May be problem with } \\
\text { instrument alignment that will delay } \\
\text { operation. }\end{array}$ \\
\hline & & 2.2.4.3/FY01/b & $\begin{array}{l}\text { PuCTF NDE System installed in LLNL Pu } \\
\text { facility }\end{array}$ & LLNL & Mar-01 & & 30 & & & Deferred to FY02. \\
\hline
\end{tabular}




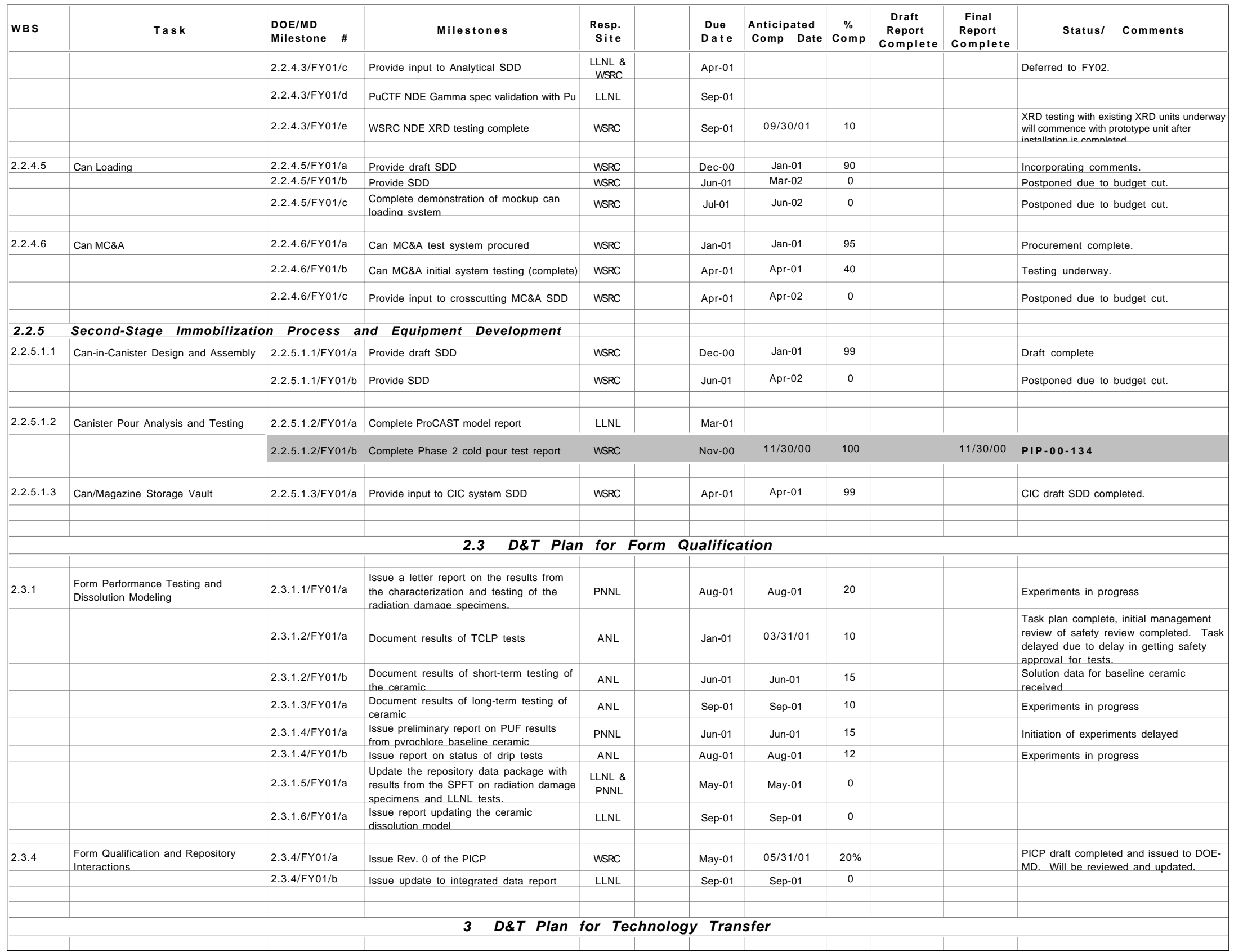




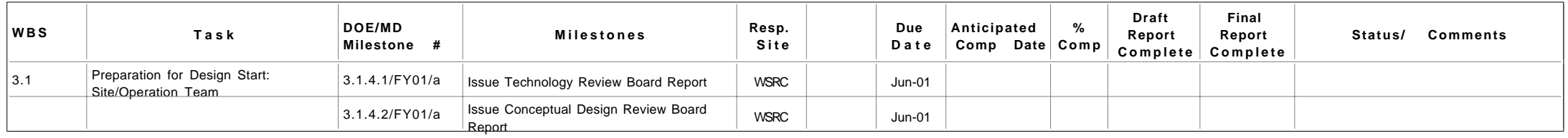


PIP-00-159

Appendix B: December FY01 Cost Summary Report 


\section{FMDP - FY01 IMMOBILIZATION}

$\$ 35,000,000$

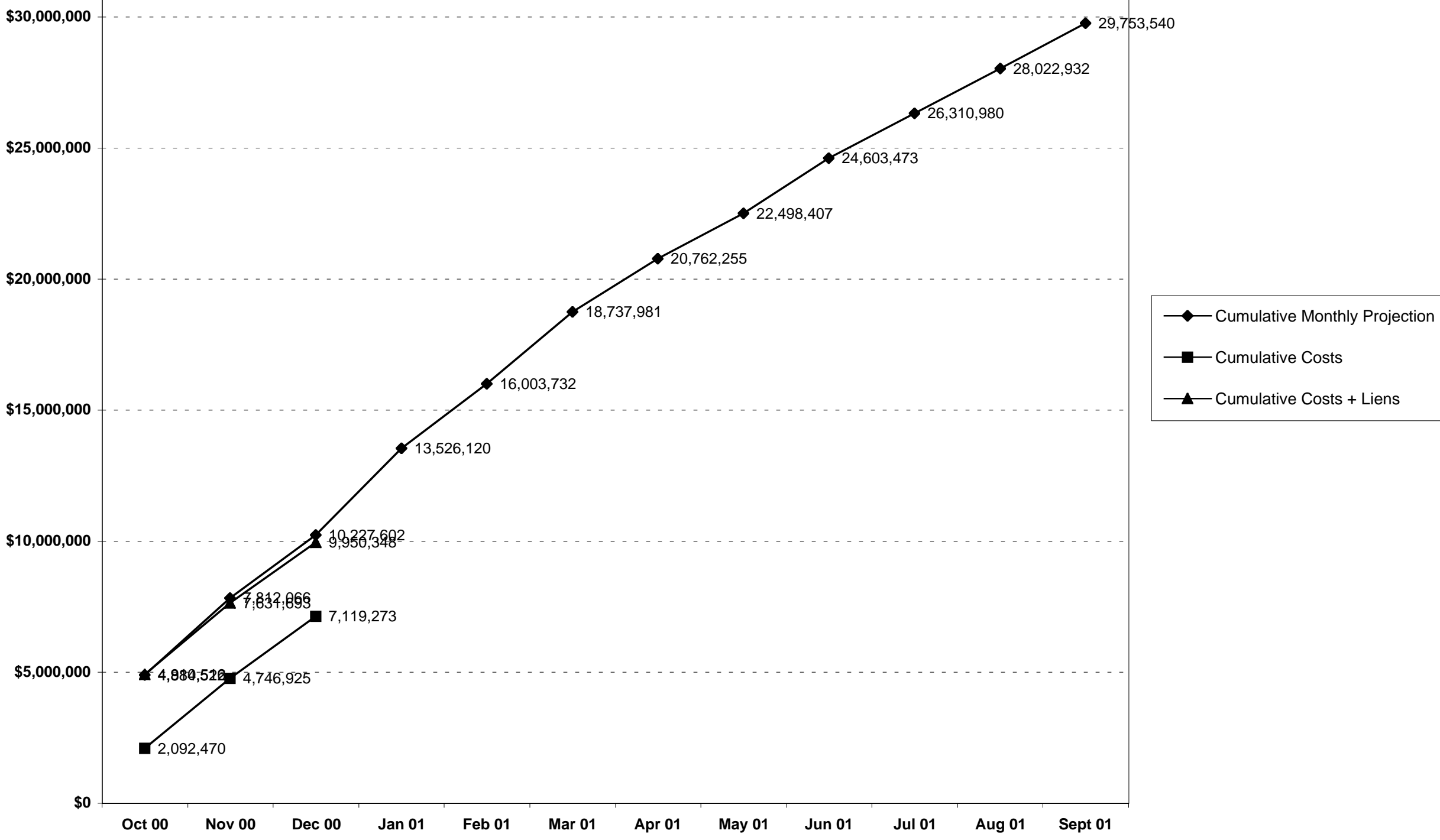


5.1.2 DOCDR Tota

\begin{tabular}{|c|c|c|c|c|c|c|c|c|c|c|c|c|c|c|}
\hline $\begin{array}{l}\text { DOCDR Total } \\
\text { LLNL, WSRC-Al Disabatino }\end{array}$ & 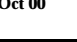 & 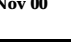 & 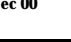 & 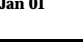 & 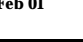 & 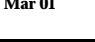 & 年 & ot & 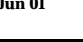 & 年 & Augor & 年 & solis & $\begin{array}{l}\text { Cum. } \\
\text { Var. }\end{array}$ \\
\hline $\begin{array}{l}\text { Manpower Projection } \\
\text { Mior Procuroment Proiection }\end{array}$ & 15,000 & $\overline{15,000}$ & 0 & 0 & 0 & 0 & 0 & 0 & 0 & 0 & 0 & 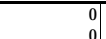 & 30,000 & \\
\hline Major Procurement Projection & & 0 & 0 & 0 & 0 & 0 & 0 & 0 & 0 & 0 & 0 & 0 & & \\
\hline $\begin{array}{l}\text { FY00 Liens } \\
\text { Total Monthly Projection }\end{array}$ & $\begin{array}{l}271,970 \\
286,970\end{array}$ & $\begin{array}{r}0 \\
15,000 \\
-100\end{array}$ & $\begin{array}{l}0 \\
0\end{array}$ & $\begin{array}{l}0 \\
0 \\
0\end{array}$ & $\begin{array}{l}0 \\
0 \\
0\end{array}$ & $\begin{array}{c}0 \\
0\end{array}$ & $\begin{array}{l}0 \\
0 \\
0\end{array}$ & $\begin{array}{l}0 \\
0\end{array}$ & $\begin{array}{l}0 \\
0 \\
0\end{array}$ & $\begin{array}{l}0 \\
0\end{array}$ & $\begin{array}{l}0 \\
0\end{array}$ & . $\left.\begin{array}{l}0 \\
0\end{array}\right]$ & $\begin{array}{l}27,1,970 \\
30,970\end{array}$ & \\
\hline $\begin{array}{l}\text { Cumulative Monthly Projection } \\
\text { Cumulative Costs }\end{array}$ & $\begin{array}{l}286,970 \\
109,515\end{array}$ & $\begin{array}{l}301,970 \\
150,110\end{array}$ & $\begin{array}{l}301,970 \\
240,181\end{array}$ & 301,970 & 301,970 & 301,970 & 301,970 & 301,970 & 301,970 & 301,970 & 301,970 & 301,970 & & $20 \%$ \\
\hline $\begin{array}{l}\text { Cumulative Costs } \\
\text { Cumulative Costs + Liens }\end{array}$ & $\begin{array}{l}109,013 \\
285,711\end{array}$ & $\begin{array}{l}150,110 \\
246,732\end{array}$ & $\begin{array}{l}240,111 \\
339,997\end{array}$ & & & & & & & & & & & $-13 \%$ \\
\hline
\end{tabular}
mulative Monthly Project
mulative Costs

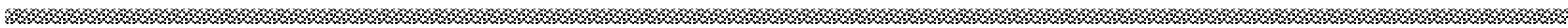

5211 Technical Project Office

\begin{tabular}{|c|c|c|c|c|c|c|c|c|c|c|c|c|c|c|}
\hline $\begin{array}{l}\text { Technical Project Office } \\
L L N L, \text { WSRC, } A N L, P N N L\end{array}$ & Oct 00 & Nov 00 & Dec 00 & Jan 01 & Feb 01 & Mar 01 & Apr 01 & May 01 & Jun 01 & Jul 01 & Aug 01 & Sept 01 & Totals & $\begin{array}{l}\text { Cum. } \\
\text { Var. }\end{array}$ \\
\hline $\begin{array}{l}\text { Manpower Projection } \\
\text { Maio Procurement Proiection }\end{array}$ & 91,203 & 310,732 & 134,371 & 148,456 & 147,371 & 178,956 & 158,094 & 158,456 & 163,094 & 183,232 & 162,732 & 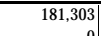 & $2,018,000$ & \\
\hline $\begin{array}{l}\text { Major Procurement Projection } \\
\text { FY00 Lijens }\end{array}$ & & & & & & & & & & & & & & \\
\hline $\begin{array}{l}\text { FYoo Liens } \\
\text { Total Monthly Projection }\end{array}$ & $\begin{array}{l}116,572 \\
207,775\end{array}$ & $\begin{array}{r}0 \\
310,732\end{array}$ & $\begin{array}{r}0 \\
134,371\end{array}$ & $\begin{array}{r}0 \\
148,456\end{array}$ & $\begin{array}{r}0 \\
147,371\end{array}$ & $\begin{array}{r}0 \\
178,956\end{array}$ & $\begin{array}{r}0 \\
158,094\end{array}$ & $\begin{array}{r}0 \\
158456\end{array}$ & $\begin{array}{r}0 \\
163094\end{array}$ & $\begin{array}{r}0 \\
183232\end{array}$ & $\begin{array}{r}0 \\
162732 \\
103\end{array}$ & $\begin{array}{r}0 \\
181,303 \\
1\end{array}$ & 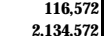 & \\
\hline Cumulative Monthly Projection & 207,775 & 518,507 & 652,878 & 801,334 & 948,705 & $1,127,661$ & $1,285,755$ & $1,444,211$ & $1,607,305$ & $1,790,537$ & $1,953,269$ & $2,134,572$ & & \\
\hline $\begin{array}{l}\text { Cumulative Costs } \\
\text { Cumulative Costs + Liens }\end{array}$ & $\begin{array}{r}89,019 \\
205,591\end{array}$ & $\begin{array}{l}223,915 \\
495,169\end{array}$ & $\begin{array}{l}338,282 \\
609,572\end{array}$ & & & & & & & & & & & $48 \%$ \\
\hline
\end{tabular}

5212

\begin{tabular}{|c|c|c|c|c|c|c|c|c|c|c|c|c|c|c|}
\hline $\begin{array}{l}\text { QA } \\
\text { LLNL WSRC, ANL PNNL }\end{array}$ & Oct 00 & Nov 00 & Dec 00 & Jan 01 & Feb 01 & Mar 01 & Apr 01 & May 01 & Jun 01 & Jul 01 & Aug 01 & Sept 01 & Totals & $\begin{array}{l}\text { Cum. } \\
\text { var. }\end{array}$ \\
\hline power Projection & 504,109 & 43,094 & 40,204 & 51,049 & 58,823 & 62,242 & 57,835 & 55,642 & 52,235 & 56,200 & 58,287 & $60,280 \mid$ & $1,100,000$ & \\
\hline r Procurement Projection & & & & & 0 & & & 0 & 0 & 0 & 0 & 0 & & \\
\hline $\begin{array}{l}\text { FY00 Liens } \\
\text { Total Monthly Projection }\end{array}$ & $\begin{array}{r}78,529 \\
582,638\end{array}$ & $\begin{array}{r}0 \\
43,094\end{array}$ & 40,204 & $\begin{array}{r}0 \\
51,049\end{array}$ & $\begin{array}{r}0 \\
58,823\end{array}$ & 62.242 & $\begin{array}{r}0 \\
57.835\end{array}$ & $\begin{array}{r}0 \\
55,642\end{array}$ & $\begin{array}{r}0 \\
52,235\end{array}$ & $\begin{array}{r}0 \\
56,200\end{array}$ & $\begin{array}{r}0 \\
58,287\end{array}$ & $\begin{array}{r}0 \\
60,280\end{array}$ & $\begin{array}{r}78,529 \\
1,178,529\end{array}$ & \\
\hline unlative Monthly Projection & $\frac{58,2638}{582,638}$ & $\frac{52,054}{625,732}$ & 665,936 & $\frac{51,049}{716,985}$ & $\frac{58,823}{775,808}$ & $\frac{62,242}{838,050}$ & 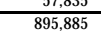 & $\frac{53,642}{951,527}$ & $\frac{52,233}{1,003,762}$ & $\frac{50,200}{1,059,962}$ & $\begin{array}{r}58,287 \\
1118,249\end{array}$ & $\begin{array}{r}60,280 \mid \\
1178,529\end{array}$ & $1,178,529$ & \\
\hline & 112,909 & 187,178 & 258,854 & & & & & & & & & & & $\%$ \\
\hline Cumulative Costs + Liens & 624,545 & 670,459 & & & & & & & & & & & & $\%$ \\
\hline
\end{tabular}

2,018,000 New FY01 Funds
116,572 Comm. C / O

0 Uncommitted C/O
2,134,572 Total FY01 Funding

5.2.1.3 Technical Documentation Oct 00

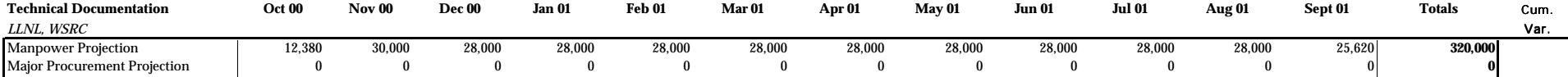
Thot Liens otal Monthly Projection Cumulative Monthly Proje
Cumulative Costs
cumulative Costs + Liens

\begin{tabular}{|c|c|c|c|c|c|c|c|c|c|c|c|c|c|}
\hline $\begin{array}{r}12,380 \\
0\end{array}$ & $\begin{array}{r}30,000 \\
0\end{array}$ & $\begin{array}{r}28,000 \\
0\end{array}$ & $\begin{array}{r}28,000 \\
0\end{array}$ & $\begin{array}{r}28,000 \\
0\end{array}$ & $\begin{array}{r}28,000 \\
0\end{array}$ & $\begin{array}{r}28,000 \\
0\end{array}$ & $\begin{array}{r}28,000 \\
0\end{array}$ & $\begin{array}{r}28,000 \\
0\end{array}$ & 28,000 & 28,000 & \begin{tabular}{|c|}
25,620 \\
\end{tabular} & $\begin{array}{r}320,000 \\
0\end{array}$ & \\
\hline 164,500 & & & & & & & & & & 0 & & 164,500 & \\
\hline 176,880 & 30,000 & 28,000 & 28,000 & 28,000 & 28,000 & 28,000 & 28,000 & 28,000 & 28,000 & 28,000 & 25,620 & 484,500 & \\
\hline $\begin{array}{r}176,880 \\
11,861\end{array}$ & $\begin{array}{r}206,880 \\
44,945\end{array}$ & $\begin{array}{r}234,880 \\
49,605\end{array}$ & 262,880 & 290,880 & 318,880 & 346,880 & 374,880 & 402,880 & 430,880 & 458,880 & 484,500 & & $79 \%$ \\
\hline 176,174 & 190,086 & 197,343 & & & & & & & & & & & $6 \%$ \\
\hline
\end{tabular}

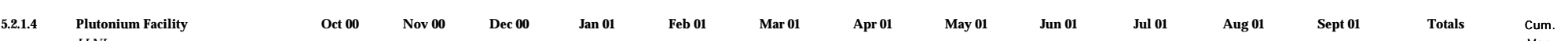

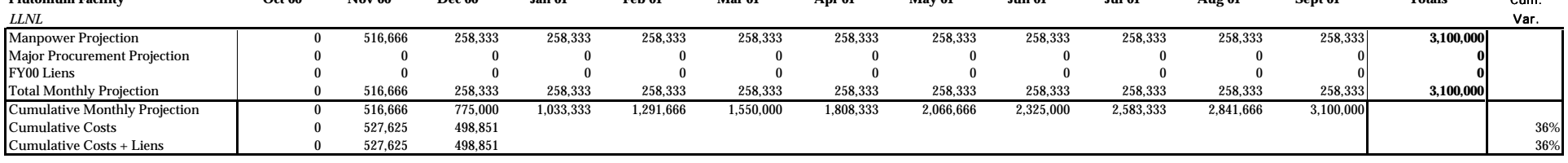

521 Der The Mar

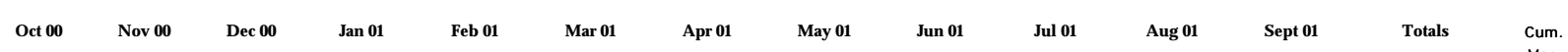

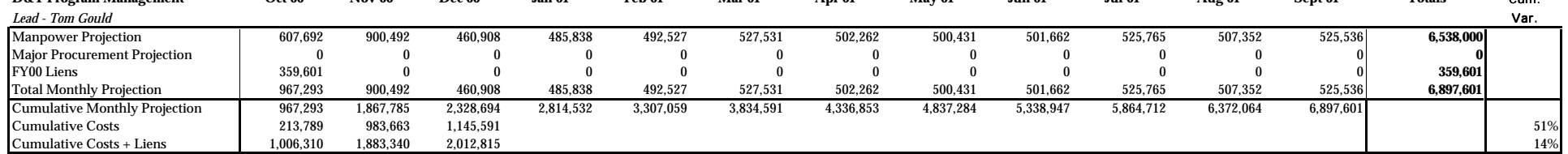

3,100,000 New FY01 Funds

0 Comm. C/O
0 Uncommitted C/O

3,100,000 Total FY01 Funding

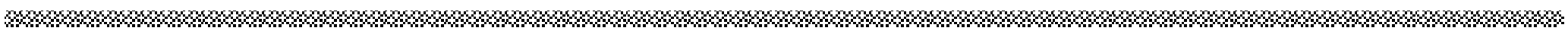

Feed Materials Characterization and
5lending

Blending
\begin{tabular}{|l|l|l}
\hline$L N L$, WSRC \\
\hline Manpower Projection \\
Major Procurement Projection \\
FYO0 Liens \\
Total Monthly Projection \\
\hline Cumulative Monthly Projection \\
Cumulative Costs \\
Cumulative Costs + Liens \\
\hline
\end{tabular}

Oct $00 \quad$ Nov $00 \quad$ Dec 00

\begin{tabular}{rrrr} 
& Feb 01 & \multicolumn{1}{c}{ Mar 01 } & \multicolumn{1}{c}{ Apr 01 } \\
\hline 5,000 & 18,000 & 20,000 & 22,300 \\
0 & 0 & 0 & 0 \\
0 & 0 & 0 & 0 \\
5,000 & 18,000 & 20,000 & 22,300 \\
44,045 & 132,045 & 152,045 & 174,345
\end{tabular}

\begin{tabular}{rr} 
May 01 & Ju \\
\hline 22,300 \\
0 \\
0 \\
22,300 \\
\hline 196,645 \\
\hline
\end{tabular}

$\begin{array}{r}\text { Jun } 01 \\ 22,300 \\ 0 \\ 0 \\ 22,300 \\ \hline 218,945 \\ \hline\end{array}$

$\begin{array}{r}\text { Jul } 01 \\ 22,300 \\ 0 \\ 0 \\ 22,300 \\ \hline 241,245\end{array}$

$\begin{array}{r}\text { Aug } 01 \\ \hline 22,300 \\ 0 \\ 0 \\ 22,300 \\ \hline 263,545 \\ \hline\end{array}$

$\begin{array}{r}22,50 \\ 22,500 \\ 286,04 \\ \hline\end{array}$

\begin{tabular}{r|r|}
\multicolumn{1}{|c|}{ Totals } & \multicolumn{1}{c}{$\begin{array}{c}\text { Cum. } \\
\text { Var. }\end{array}$} \\
\hline 285,000 & 0 \\
1,045 & \\
286,045 & \\
& \\
& $-2 \%$ \\
\hline
\end{tabular}




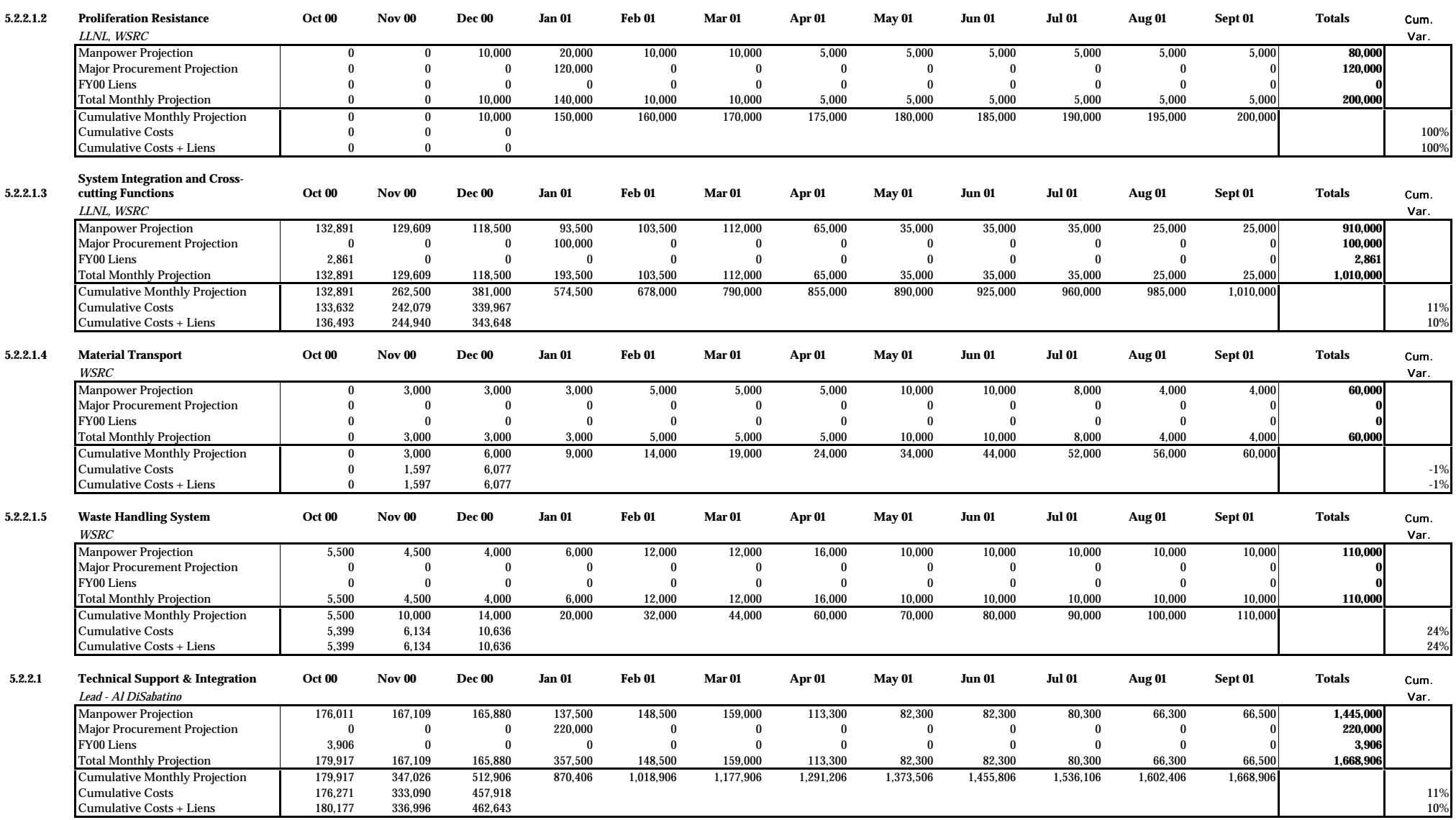

00,000 New FY01 Funds 0 Uncommitted C/O
200,000 Total FY01 Funding

«\%

5.2.2.2.3 Developme

\begin{tabular}{|c|c|c|c|c|c|c|c|c|c|c|c|c|c|c|}
\hline $\begin{array}{l}\text { Development } \\
L L N L \text {, WSRC }\end{array}$ & Oct too & . & . Dets & 年 & Tedor & War of & Aprove & Nay or & 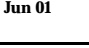 & Jartor & Aug or & Sept v1 & Totals & $\begin{array}{l}\text { Cum. } \\
\text { var. }\end{array}$ \\
\hline \begin{tabular}{|l|} 
Manpower Projection \\
Major Procurement Projection
\end{tabular} & $\begin{array}{r}113,700 \\
0\end{array}$ & $\begin{array}{c}97,100 \\
0\end{array}$ & $\begin{array}{r}70,300 \\
0\end{array}$ & $\begin{array}{r}70,300 \\
0\end{array}$ & $\begin{array}{r}77,100 \\
0\end{array}$ & $\begin{array}{r}71,800 \\
0\end{array}$ & $\begin{array}{r}10,300 \\
0\end{array}$ & $\begin{aligned} 16,200 \\
0\end{aligned}$ & $\begin{array}{r}\begin{array}{r}13,700 \\
0\end{array} \\
0\end{array}$ & $\begin{array}{r}11,000 \\
0\end{array}$ & $\begin{array}{r}16,200 \\
0\end{array}$ & $\left.\begin{array}{rl|r}16,300 \\
0\end{array}\right]$ & $\begin{aligned} 584,000 \\
0\end{aligned}$ & \\
\hline $\begin{array}{l}\text { FY00 Liens } \\
\text { Total Monthly Proiection }\end{array}$ & $\begin{array}{r}91,708 \\
205408\end{array}$ & $\begin{array}{r}0 \\
97100\end{array}$ & $\begin{array}{r}0 \\
70300\end{array}$ & $\begin{array}{r}0 \\
70300\end{array}$ & $\begin{array}{r}0 \\
77100\end{array}$ & $\begin{array}{r}0 \\
71800\end{array}$ & $\begin{array}{r}0 \\
10300\end{array}$ & $\begin{array}{r}0 \\
16200\end{array}$ & $\begin{array}{r}0 \\
13700\end{array}$ & $\begin{array}{r}0 \\
11000\end{array}$ & $\begin{array}{r}0 \\
16200\end{array}$ & $\left.\begin{array}{r}0 \\
1630\end{array}\right]$ & $\begin{array}{r}91,708 \\
675708\end{array}$ & \\
\hline \begin{tabular}{|l} 
Total Monthly Projection \\
Cumulative Monthly Projection
\end{tabular} & $\begin{array}{ll}200,400 \\
205,408\end{array}$ & $\begin{array}{ll}9,1,500 \\
302,58\end{array}$ & $\frac{10,200}{372,808}$ & 443,108 & 520,208 & $\frac{11,000}{592,008}$ & $\frac{1,000}{602,308}$ & $\frac{10,200}{618,508}$ & $\frac{1,2000}{632,208}$ & $\frac{11,1000}{643,208}$ & $\frac{10,200}{659,408}$ & $\mid \frac{1,0300}{675,708}$ & & \\
\hline $\begin{array}{l}\text { Cumulative Costs } \\
\text { Cumulative Costs + Liens }\end{array}$ & $\begin{array}{l}100,636 \\
203,343\end{array}$ & $\begin{array}{l}175,487 \\
275,859\end{array}$ & $\begin{array}{l}309,944 \\
359,652\end{array}$ & & & & & & & & & & & $\begin{array}{r}17 \% \\
4 \%\end{array}$ \\
\hline
\end{tabular}

\section{Oct $00 \quad$ Nov $00 \quad$ Dec $00 \quad$ Jan 0}

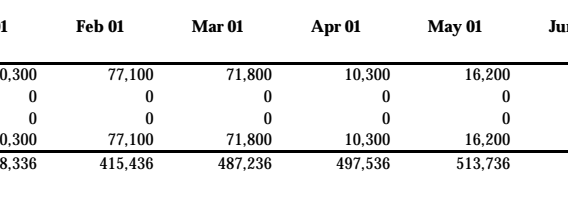

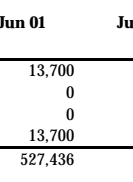

\begin{tabular}{rr} 
Jul 01 & Aug 01 \\
\hline 11,000 & 16,200 \\
0 & 0 \\
0 & 0 \\
11,000 & 16,200 \\
\hline 538,436 & 554,636
\end{tabular}

$\begin{array}{r}\text { Sept } 01 \\ \hline 16,300 \\ 0 \\ 0 \\ 16,300 \\ \hline 570,936 \\ \hline\end{array}$

Totals

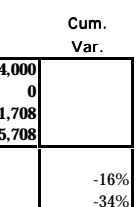

91,708 Comm. C/O

0 Uncommitted C/O
675,708 Total FY01 Funding

Lead - Guy Armantrout

FY00 Liens
Total Monthly Projection
Cumulative Monthly Projection \begin{tabular}{lll}
100,636 & 197,736 & 26,487 \\
170,036 & 309,944 \\
\hline & 175,487 & 3596
\end{tabular} 


\begin{tabular}{|c|c|c|c|c|c|c|c|c|c|c|c|c|c|c|c|c|}
\hline 5.2.2.3.1. & $\begin{array}{l}\text { Material Receipt and Storage } \\
\text { WSRC }\end{array}$ & Oct 00 & Nov 00 & Dec 00 & $\operatorname{Jan} 01$ & Feb 01 & Mar 01 & Apr 01 & May 01 & Jun 01 & Jul 01 & Aug 01 & Sept 01 & Totals & $\begin{array}{l}\text { Cum. } \\
\text { var. }\end{array}$ & \multirow{6}{*}{$\begin{array}{l}\text { 55,000 New FY01 Funds } \\
0 \text { Comm. C/O } \\
0 \text { Uncommitted C/O } \\
55,000 \text { Total FY01 Funding }\end{array}$} \\
\hline & \begin{tabular}{|l} 
Manpower Projection \\
Major Procurement Projection
\end{tabular} & 01 & $5,000 \mid$ & $5,000 \mid$ & 5,000 & $5,000 \mid$ & $5,000 \mid$ & 5,5000 & $5,000 \mid$ & $|5,000|$ & $5,000 \mid$ & $|5,000|$ & \begin{tabular}{|c|r|r|}
5,000 \\
\end{tabular} & 55,000 & & \\
\hline & $\begin{array}{l}\text { Major Procurement Projection } \\
\text { FY00 Liens }\end{array}$ & & 0 & 0 & & 0 & $\begin{array}{l}0 \\
0\end{array}$ & $\begin{array}{l}0 \\
0\end{array}$ & $\begin{array}{l}0 \\
0\end{array}$ & ${ }_{0}^{0}$ & $\begin{array}{l}0 \\
0\end{array}$ & 0 & $\begin{array}{c}0 \\
0\end{array}$ & & & \\
\hline & Total Monthly Projection & 0 & 5,000 & 5,000 & 5,000 & 5,000 & 5,000 & 5,000 & 5,000 & 5,000 & 5,000 & 5,000 & 5,000 & 55,000 & & \\
\hline & Cumulative Monthly Projection & 0 & 5,000 & 10,000 & 15,000 & 20,000 & 25,000 & 30,000 & 35,000 & 40,000 & 45,000 & 50,000 & 55,000 & & & \\
\hline & $\begin{array}{l}\text { Cumulative Costs } \\
\text { Cumulative Costs + Liens }\end{array}$ & $\begin{array}{l}0 \\
0\end{array}$ & $\begin{array}{l}2,7,701 \\
2,701\end{array}$ & $\begin{array}{l}10,066 \\
10,066\end{array}$ & & & & & & & & & & & $\begin{array}{l}-1 \% \\
-1 \%\end{array}$ & \\
\hline \multirow[t]{6}{*}{ 5.2.2.3.3 } & $\begin{array}{l}\text { Material Size Reduction } \\
L L N L \text {, WSRC }\end{array}$ & Oct 00 & Nov 00 & Dec 00 & $\operatorname{Jan} 01$ & Feb 01 & Mar 01 & Apr 01 & May 01 & Jun 01 & Jul 01 & Aug 01 & Sept 01 & Totals & $\begin{array}{l}\text { Cum. } \\
\text { Var. }\end{array}$ & \multirow{6}{*}{$\begin{array}{l}\text { 30,000 New FY01 Funds } \\
0 \text { Comm. C/O } \\
0 \text { Uncommitted C/O } \\
\text { 30,000 Total FY01 Funding }\end{array}$} \\
\hline & & 0 & 0 & 7,500 & 7,500 & 7,500 & 7,500 & 0 & 0 & 0 & 0 & 0 & & 30,000 & & \\
\hline & Major Procurement Projection & 0 & 0 & 0 & 0 & 0 & 0 & 0 & 0 & 0 & 0 & 0 & & & & \\
\hline & $\begin{array}{l}\text { FYoo Liens } \\
\text { Total Monthly Projection }\end{array}$ & $\begin{array}{l}0 \\
0\end{array}$ & $\begin{array}{l}0 \\
0\end{array}$ & $\begin{array}{r}0 \\
7500\end{array}$ & $\begin{array}{r}0 \\
7500\end{array}$ & $\begin{array}{r}0 \\
7500\end{array}$ & $\begin{array}{r}0 \\
7500\end{array}$ & 0 & $\begin{array}{l}0 \\
0\end{array}$ & $\begin{array}{l}0 \\
0\end{array}$ & $\begin{array}{l}0 \\
0\end{array}$ & $\begin{array}{l}0 \\
0\end{array}$ & \begin{tabular}{c|c}
0 \\
0 \\
0
\end{tabular} & 3000 & & \\
\hline & Cumulative Monthly Projection & 0 & 0 & 7,500 & 15,000 & $\frac{1,500}{22,500}$ & $\frac{3,000}{30,000}$ & 30,000 & 30,000 & 30,000 & 30,000 & 30,000 & $\frac{0}{30,000}$ & & & \\
\hline & $\begin{array}{l}\text { Cumulative Costs } \\
\text { Cumulative Costs + Liens }\end{array}$ & $\begin{array}{l}-2,270 \\
-2,270\end{array}$ & $\begin{array}{l}-2,270 \\
-2,270\end{array}$ & $\begin{array}{l}-2,270 \\
-2,270\end{array}$ & & & & & & & & & & & $\begin{array}{l}130 \% \\
130 \%\end{array}$ & \\
\hline \multirow[t]{7}{*}{ 5.2.2.3.4. } & Material Unpacking and Sorting & Oct 00 & Nov 00 & Dec 00 & Jan 01 & Feb 01 & Mar 01 & Apr 01 & May 01 & Jun 01 & Jul 01 & Aug 01 & Sept 01 & Totals & $\begin{array}{l}\text { Cum. } \\
\text { Var. }\end{array}$ & \multirow{8}{*}{$\begin{array}{l}\text { 125,000 New FY01 Funds } \\
\text { 0 Comm. C/O } \\
\text { 0 Uncommitted C/O } \\
\text { 125,000 Total FY01 Funding }\end{array}$} \\
\hline & Manpower Projection & 10,000 & 7,600 & 9,600 & 14,600 & 15,600 & 16,000 & 9,600 & 7,600 & 9,600 & 7,600 & 9,600 & 7,600 & 125,000 & & \\
\hline & Major Procurement Projection & 0 & 0 & 0 & 0 & 0 & 0 & 0 & & & & & & & & \\
\hline & FY00 Liens & 0 & 0 & 0 & 0 & 0 & 0 & 0 & 0 & 0 & 0 & & 0 & & & \\
\hline & Total Monthly Projection & 10,000 & 7,600 & 9,600 & 14,600 & 15,600 & 16,000 & 9,600 & 7,600 & 9,600 & 7,600 & 9,600 & 7,600 & 125,000 & & \\
\hline & Cumulative Monthly Projection & $\begin{array}{ll}10,000 \\
0.02\end{array}$ & 17,600 & 27,200 & 41,800 & 57,400 & 73,400 & 83,000 & 90,600 & 100,200 & 107,800 & 117,400 & 125,000 & & & \\
\hline & $\mid \begin{array}{l}\text { Cumulativiv Costs } \\
\text { Cumulative Costs + Liens }\end{array}$ & $\begin{array}{l}9,830 \\
9,830\end{array}$ & $\begin{array}{l}16,245 \\
16,245\end{array}$ & $\begin{array}{l}23,034 \\
23,034\end{array}$ & & & & & & & & & & & $\begin{array}{l}15 \% \\
15 \%\end{array}$ & \\
\hline \multirow[t]{7}{*}{ 5.2.2.3.6 } & Metal Conversion & Oct 00 & Nov 00 & Dec 00 & Jan 01 & Feb 01 & Mar 01 & Apr 01 & May 01 & Jun 01 & Jul 01 & Aug 01 & Sept 01 & Totals & $\begin{array}{l}\text { Cum. } \\
\text { var. }\end{array}$ & \\
\hline & Manpower Projection & 160,000 & 240,000 & 160,000 & 450,000 & 220,000 & 210,000 & 151,000 & 0 & 0 & 0 & 0 & & $1,591,000$ & & \multirow{7}{*}{$\begin{array}{l}\text { 1,591,000 New FY01 Funds } \\
\text { 18,204 Comm. C/O } \\
\text { 0 Uncommitted C/O } \\
\text { 1,609,204 Total FY01 Funding }\end{array}$} \\
\hline & Major Procurement Projection & 0 & & & & & & & 0 & 0 & 0 & 0 & & 0 & & \\
\hline & FY00 Liens & 18,204 & & & & & & & 0 & 0 & 0 & 0 & 0 & 18,204 & & \\
\hline & Total Monthly Projection & 178,204 & 240,000 & 160,000 & 450,000 & 220,000 & 210,000 & 151,000 & 0 & 0 & 0 & 0 & 0 & $1,609,204$ & & \\
\hline & Cumulative Monthly Projection & 178,204 & 418,204 & 578,204 & $1,028,204$ & $1,248,204$ & $1,458,204$ & $\begin{array}{ll}1,609,204 \\
\end{array}$ & $1,609,204$ & $1,609,204$ & $\begin{array}{ll}1,609,204 \\
\end{array}$ & $\begin{array}{ll}1,609,204 \\
\end{array}$ & \begin{tabular}{|l|}
$1,609,204$ \\
\end{tabular} & & & \\
\hline & $\mid \begin{array}{l}\text { Cumulative Costs } \\
\text { Cumulative Costs + Liens }\end{array}$ & $\begin{array}{l}137,1,97 \\
168,972\end{array}$ & $\begin{array}{l}{ }_{4}^{461,164} \\
491,79\end{array}$ & $\begin{array}{r}800,732 \\
11190298\end{array}$ & & & & & & & & & & & $\begin{array}{c}-38 \% \\
-92 \%\end{array}$ & \\
\hline \multirow[t]{6}{*}{ 5.2.2.3.7 } & Impure Oxide Feed Preparation & Oct 00 & Nov 00 & Dec 00 & Jan 01 & Feb 01 & Mar 01 & Apr 01 & May 01 & Jun 01 & Jul 01 & Aug 01 & Sept 01 & Totals & $\begin{array}{l}\text { Cum. } \\
\text { Var. }\end{array}$ & \\
\hline & Manpower Projection & 25,000 & 45,000 & 45,000 & 85,000 & 35,000 & 50,000 & 20,000 & 30,000 & 30,000 & 20,000 & 20,000 & 15,000 & 420,000 & & \multirow{5}{*}{$\begin{array}{l}\text { 420,000 New FY01 Funds } \\
\text { 0 Comm. C/O } \\
\text { 0 Uncommitted C/O } \\
\text { 420,000 Total FY01 Funding }\end{array}$} \\
\hline & Major Procurement Projection & 0 & 0 & 0 & & & 0 & 0 & & & & & & & & \\
\hline & $\begin{array}{l}\text { Fotal Mons } \\
\text { Tylyly Projection }\end{array}$ & $\begin{array}{r}0 \\
25,000\end{array}$ & $\begin{array}{r}0 \\
45,000\end{array}$ & $\begin{array}{r}0 \\
45,000\end{array}$ & $\begin{array}{r}0 \\
85,000\end{array}$ & $\begin{array}{r}0 \\
35,000\end{array}$ & 50,000 & $\begin{array}{r}0 \\
20,000\end{array}$ & $\begin{array}{r}0 \\
30,000\end{array}$ & $\begin{array}{r}0 \\
30,000\end{array}$ & $\begin{array}{r}0 \\
20,000\end{array}$ & 20,000 & 15,000 & $\begin{array}{r}420,000 \\
4\end{array}$ & & \\
\hline & Cumulative Monthly Projection & 25,000 & 70,000 & 115,000 & 200,000 & 235,000 & 285,000 & 305,000 & 335,000 & 365,000 & 385,000 & 405,000 & 420,000 & & & \\
\hline & Cumulative Costs & 24,078 & 49,606 & 111,596 & & & & & & & & & & & $3 \%$ & \\
\hline \multirow[t]{7}{*}{ 5.2.2.3.8 } & $\begin{array}{l}\text { Materials Characterization } \\
L I N L \text { WSRC }\end{array}$ & Oct 00 & Nov 00 & Dec 00 & $\operatorname{Jan} 01$ & Feb 01 & Mar 01 & Apr 01 & May 01 & Jun 01 & Jul 01 & Aug 01 & Sept 01 & Totals & Cum. & \multirow{7}{*}{$\begin{array}{l}\text { 640,000 New FY01 Funds } \\
20,905 \text { Comm. C/O } \\
0 \text { Uncommitted C/O } \\
660,905 \text { Total FY01 Funding }\end{array}$} \\
\hline & Manpower Projection & 51,200 & 71,100 & 67,100 & 62,100 & 60,100 & 47,100 & 40,800 & 46,100 & 44,200 & 41,700 & 45,000 & 63,500 & 640,000 & & \\
\hline & Major Procurement Projection & 0 & & 0 & 0 & 0 & 0 & 0 & 0 & 0 & 0 & 0 & & 0 & & \\
\hline & FY00 Liens & $\begin{array}{l}20,905 \\
72015\end{array}$ & 0 & 0 & 0 & 0 & 0 & 0 & 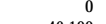 & 0 & & 0 & 0 & 20,905 & & \\
\hline & Total Monthly Projection & 72,105 & 71,100 & 67,100 & 62,100 & 60,100 & 47,100 & 40,800 & 46,100 & 44,200 & 41,700 & 45,000 & 63,500 & & & \\
\hline & Cumulative Monthly Projection & 72,105 & $\begin{array}{l}143,205 \\
\end{array}$ & $\begin{array}{r}210,305 \\
22758\end{array}$ & 272,405 & 332,505 & 379,605 & 420,405 & 466,505 & 510,705 & 552,405 & 597,405 & 660,905 & & & \\
\hline & Cumulative Costs + Liens & 72,005 & 153,923 & 228,316 & & & & & & & & & & & $-9 \%$ & \\
\hline \multirow[t]{7}{*}{ 5.2.2.3.9. } & $\begin{array}{l}\text { Material Control and Accountability } \\
\text { WSRC }\end{array}$ & Oct 00 & Nov 00 & Dec 00 & Jan 01 & Feb 01 & Mar 01 & Apr 01 & May 01 & Jun 01 & Jul 01 & Aug 01 & Sept 01 & Totals & $\begin{array}{l}\text { Cum. } \\
\text { Var. }\end{array}$ & \multirow{8}{*}{$\begin{array}{l}\text { 22,000 New FY01 Funds } \\
0 \text { Comm. C/O } \\
0 \text { Uncommitted C/O } \\
\text { 22,000 Total FY01 Funding }\end{array}$} \\
\hline & Manpower Projection & 0 & 0 & 0 & 5,000 & 5,000 & 6,000 & 6,000 & 0 & 0 & 0 & 0 & $\overline{0}$ & 22,000 & & \\
\hline & Major Procurement Projection & 0 & 0 & 0 & 0 & 0 & 0 & 0 & 0 & 0 & 0 & 0 & 0 & & & \\
\hline & $\begin{array}{l}\text { FYoo Liens } \\
\text { Total Monthly Projection }\end{array}$ & $\begin{array}{l}0 \\
0\end{array}$ & $\begin{array}{l}0 \\
0\end{array}$ & $\begin{array}{l}0 \\
0\end{array}$ & $\begin{array}{r}0 \\
5,000\end{array}$ & $\begin{array}{r}0 \\
5,000\end{array}$ & $\begin{array}{r}0 \\
6,000\end{array}$ & $\begin{array}{r}0 \\
6,000\end{array}$ & $\begin{array}{l}0 \\
0\end{array}$ & $\begin{array}{l}0 \\
0\end{array}$ & $\begin{array}{l}0 \\
0\end{array}$ & $\begin{array}{l}0 \\
0 \\
0\end{array}$ & $\begin{array}{l}0 \\
0 \\
0\end{array}$ & $\begin{array}{r}0 \\
22,000\end{array}$ & & \\
\hline & Cumulative Monthly Projection & 0 & 0 & 0 & 5,000 & 10,000 & 16,000 & 22,000 & 22,000 & 22,000 & 22,000 & 22,000 & $22,000 \mid$ & & & \\
\hline & Cumulative Costs & 0 & 0 & 0 & & & & & & & & & & & \#DIV/0! & \\
\hline & Cumulative Costs + Liens & 0 & 0 & 0 & & & & & & & & & & & \#DIV/0! & \\
\hline \multirow[t]{7}{*}{ 5.2.2.2.3.10 } & $\begin{array}{l}\text { In-Process Storage Vault } \\
\text { WSRC }\end{array}$ & Oct 00 & Nov 00 & Dec 00 & $\operatorname{Jan} 01$ & Feb 01 & Mar 01 & Apr 01 & May 01 & Jun 01 & Jul 01 & Aug 01 & Sept 01 & Totals & $\begin{array}{l}\text { Cum. } \\
\text { Var. }\end{array}$ & \\
\hline & Manpower Projection & 0 & 0 & 0 & 5,000 & 5,000 & 5,000 & 5,000 & 0 & 0 & 0 & 0 & $\overline{0}$ & 20,000 & & \\
\hline & Major Procurement Projection & 0 & 0 & 0 & 0 & 0 & 0 & 0 & 0 & 0 & 0 & 0 & 0 & 0 & & 0 Comm. C/O \\
\hline & $\begin{array}{l}\text { FY00 Liens } \\
\text { Totat Monthly Projection }\end{array}$ & 0 & 0 & 0 & $\begin{array}{r}0 \\
5000\end{array}$ & 50 & 0 & 5000 & 0 & 0 & 0 & 0 & 0 & 0 & & 0 Uncommitted C/O \\
\hline & Total Monthly Projection & 0 & 0 & 0 & 5,000 & $\frac{5,000}{1000}$ & $\frac{5,000}{1500}$ & $\frac{5,000}{2000}$ & 0 & $\frac{0}{20000}$ & $\frac{0}{20000}$ & $\frac{0}{00}$ & $\frac{0}{0001}$ & 20,000 & & \\
\hline & $\begin{array}{l}\begin{array}{l}\text { Cumulative Monthly Projection } \\
\text { Cumulative Costs }\end{array} \\
\text {. }\end{array}$ & $\begin{array}{l}0 \\
0\end{array}$ & $\begin{array}{l}0 \\
0\end{array}$ & $\begin{array}{l}0 \\
0\end{array}$ & 5,000 & 10,000 & 15,000 & 20,000 & 20,000 & 20,000 & 20,000 & 20,000 & & & $/ 0 !$ & \\
\hline & Cumulative Costs + Liens & 0 & 0 & 0 & & & & & & & & & & & \#DIV $/ 0 !$ & \\
\hline
\end{tabular}


5.2.2.3 Plutonium Conversion Total

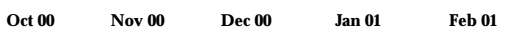

Mar $01 \quad$ Apr $01 \quad$ May $01 \quad$ Jun 01 \begin{tabular}{|rrr|r|r|} 
Jul 01 & Aug 01 & \multicolumn{1}{c}{ Sept 01 } & \multicolumn{1}{c}{ Totals } & $\begin{array}{l}\text { Cum. } \\
\text { Var. }\end{array}$ \\
\hline 74,300 & 79,600 & 91,100 & $2,903,000$ & \\
0 & 0 & 0 & 39 & \\
0 & 0 & 99,109 & \\
74,300 & 79,600 & 91,100 & $2,942,109$ & \\
\hline $2,771,409$ & $2,851,009$ & $2,942,109$ & & $-23 \%$ \\
& & & & $-56 \%$ \\
\hline
\end{tabular} Lead -Mark Bronson Major Procurement Projection
FY00 Liens Total Monthly Projection
Cumulative Monthly Projection Cumulative Monthly
Cumulative Costs
Cummulative Costs

\begin{tabular}{|c|c|c|c|c|c|c|c|c|c|c|c|c|c|}
\hline $\begin{array}{r}246,200 \\
0\end{array}$ & $\begin{array}{r}368,700 \\
0\end{array}$ & & $\begin{array}{r}634,200 \\
0\end{array}$ & & & & & & & & & & \\
\hline $\begin{array}{r}39,109 \\
\quad 255309\end{array}$ & $\begin{array}{r}0 \\
3667\end{array}$ & 0 & 0 & 0 & 0 & 0 & $\begin{array}{r}0 \\
88\end{array}$ & 0 & 0 & 0 & 0 & $\begin{array}{r}39,109 \\
\end{array}$ & \\
\hline$\frac{285,3099}{285,309}$ & $\begin{array}{l}650,100 \\
654,009\end{array}$ & $\begin{array}{l}94,48,200 \\
94809\end{array}$ & $\begin{array}{l}0.53,2000 \\
1,582,409\end{array}$ & $\begin{array}{l}353,200 \\
1,935,609\end{array}$ & $\begin{array}{l}54,282,200 \\
2,209\end{array}$ & $\frac{23,400}{2,519,609}$ & $\begin{array}{l}6,608,300 \\
\end{array}$ & $\begin{array}{r}2,897,100 \\
\end{array}$ & $\begin{array}{r}2,77,300 \\
2,71,409\end{array}$ & $\begin{array}{r}2,95,600 \\
2,851,009\end{array}$ & $\begin{array}{r}, 942,1009 \\
\end{array}$ & & \\
\hline $\begin{array}{r}219,326 \\
27261\end{array}$ & 660,464 & $\begin{array}{l}1,170,740 \\
1\end{array}$ & & & & & & & & & & & $3 \%$ \\
\hline
\end{tabular}

0 Uncommitted C/O
2,942,109 Total FY01 Funding

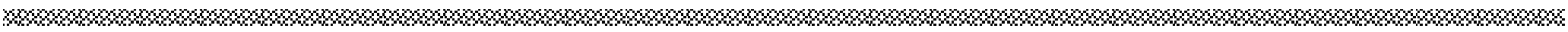

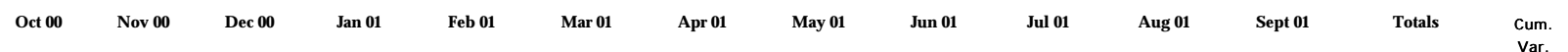

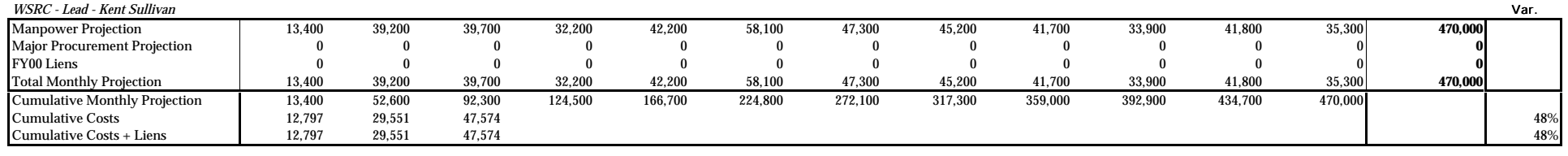

\begin{tabular}{ll} 
5.2.2.4.2.1 & $\begin{array}{l}\text { Ceramification Process } \\
\text { Development }\end{array}$ \\
\hline
\end{tabular}

$$
\text { LLNL, WSRC }
$$

Oct 00 Nov $00 \quad$ Dec $00 \quad J$

Manpower Projection

Major Procurement Projection
FYOO Liens Total Monthly Projection Cumulative Costs
Cumulative Costs + Liens

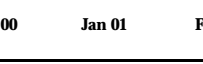

Feb 01 Mar 01 Apr 01 May 01 Ju

\begin{tabular}{lllll}
01 & Jul 01 & Aug 01 & Sept 01 & Totals \\
\hline
\end{tabular}

Cum.

Cumulative Costs + Liens

\begin{tabular}{|c|c|c|c|c|c|c|c|c|c|c|c|c|c|}
\hline $\begin{array}{r}3,500 \\
0 \\
60,073\end{array}$ & $\begin{array}{r}3,500 \\
0 \\
0\end{array}$ & $\begin{array}{r}3,500 \\
0\end{array}$ & $\begin{array}{r}3,500 \\
0 \\
0\end{array}$ & $\begin{array}{r}25,000 \\
5,000 \\
0\end{array}$ & $\begin{array}{r}30,000 \\
5,000 \\
0\end{array}$ & $\begin{array}{r}53,000 \\
5,000 \\
0\end{array}$ & $\begin{array}{r}55,000 \\
4,000 \\
0\end{array}$ & $\begin{array}{r}55,000 \\
4,000 \\
0\end{array}$ & $\begin{array}{r}\begin{array}{r}60,000 \\
4,000 \\
0\end{array} \\
0\end{array}$ & $\begin{array}{r}55,000 \\
4,000 \\
0\end{array}$ & $\begin{array}{r}55,000 \\
4,000 \\
0\end{array}$ & $\begin{array}{r}402,000 \\
35,000 \\
60,073\end{array}$ & \\
\hline $\begin{array}{l}60,0713 \\
63,573\end{array}$ & 3,500 & 3,500 & 3,500 & $\begin{array}{l}30,000 \\
\end{array}$ & 35,000 & $\begin{array}{r}0 \\
58,000\end{array}$ & 59,000 & $\begin{array}{r}0 \\
59,000\end{array}$ & 64,000 & $\begin{array}{r}59,000 \\
\end{array}$ & 59,000 & 497,073 & \\
\hline $\begin{array}{r}63,573 \\
3,418\end{array}$ & $\begin{array}{l}67,073 \\
12,292\end{array}$ & $\begin{array}{r}70,573 \\
106,838\end{array}$ & 74,073 & 104,073 & 139,073 & 197,073 & 256,073 & 315,073 & 379,073 & 438,073 & \begin{tabular}{|c|}
497,073 \\
\end{tabular} & & $-51 \%$ \\
\hline 63,492 & 72,365 & 106,911 & & & & & & & & & & & $-51 \%$ \\
\hline
\end{tabular}

$\begin{array}{ll}\text { 5.2.2.4.2.3 } & \text { Ceramification } \\ \text { Facility (CPTF) }\end{array}$

Oct $00 \quad$ Nov $00 \quad$ Decol

Jan $01 \quad$ Feb 01 $\quad$ Mar

May 01

\begin{tabular}{llll} 
Jun 01 & Jul 01 & Aug 01 & Sept 0 \\
\hline
\end{tabular}

Totals

\begin{tabular}{l} 
Cum. \\
Var. \\
\hline
\end{tabular}

\begin{tabular}{rr} 
Apr 01 \\
\hline 302,800 \\
0 \\
0 \\
0 \\
302,800 \\
\hline $3,903,088$ \\
\hline
\end{tabular}

Manpower Projection

FYo Liens
Fotal Monthly Proiection

Cumulative Monthly Projection

Cumulative Costs
Cumulative Costs +
Con \begin{tabular}{rrr}
276,39 & $1,753,988$ & $2,154,388$ \\
$1,403,659$ & $1,64,885$ & 764,4212 \\
& 1,8632 & $1,863,302$ \\
\hline
\end{tabular}

\begin{tabular}{rr}
338,300 & 761 \\
0 & \\
0 & \\
338,300 & 761 \\
\hline$, 241,388$ & 5,002 \\
&
\end{tabular}

\begin{tabular}{rrr}
0 & 429,400 & 439,700 \\
0 & 0 & 0 \\
761,300 & 429,400 & 0 \\
739,700 \\
\hline
\end{tabular}

$\begin{array}{rr} & \\ 0 & 395,00 \\ 0 & \\ & \\ & \\ 700 & 395,00 \\ & 6,266,78\end{array}$

$\begin{array}{r}r, 000 \\ 0 \\ 0 \\ 95,000 \\ \hline\end{array}$

\begin{tabular}{|r|r|}
\hline $5,139,488$ & \\
0 & \\
$1,127,300$ & \\
$6,266,788$ & \\
\hline & \\
\hline
\end{tabular}

522012 Plutonium Ceramic Test Facility

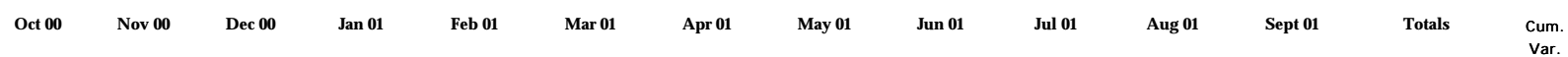

LLNL, WSRC

Manpower Projection
Major Procurement Projectio
FY00 Liens

FYo0 Liens
Total Monthly Projection

Total Monthly Projection

Cumulative Costs
Cumulative Costs + Lien

\begin{tabular}{rr}
\multicolumn{2}{c}{ Jun 01 } \\
\hline, 000 & 42,000 \\
0 & 0 \\
0 & 0 \\
0 & 42,000 \\
\hline, 000 & $3,906,678$ \\
\hline
\end{tabular}

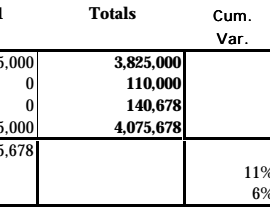

Puck NDE/MC\&A for Process
5.2.2.4.3 Control and SNM Accountability \begin{tabular}{lll}
609,415 & $1,182,405$ & $1,841,24$ \\
780,352 & $1,392,052$ & 1933714 \\
\hline & &
\end{tabular}

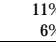

LLNL, WSRC

Major Procurement Projection

al Monthy

Cumulative Monthly Projection

Cumulative Costs
Cumulative Costs + Liens

Oct $00 \quad$ Nov $00 \quad$ Dec 00 Ja

$\begin{array}{lllll}\text { An } 01 & \text { Feb } 01 & \text { Mar } 01 & \text { Apr } 01 & \text { May }\end{array}$

\begin{tabular}{lllll} 
Jun 01 & Jul 01 & Aug 01 & Sept 01 & Totals \\
\hline
\end{tabular}

Cum.
Var.

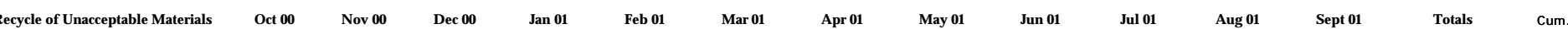

\begin{tabular}{|c|c|c|c|c|c|c|c|c|c|c|c|c|c|c|}
\hline & & & & & & & & & & & & & & var. \\
\hline \begin{tabular}{|l|} 
Manpower Projection \\
Major Procurement Projection
\end{tabular} & $\begin{array}{l}0 \\
0\end{array}$ & $\begin{array}{l}0 \\
0 \\
0\end{array}$ & $\begin{array}{l}0 \\
0\end{array}$ & $\begin{array}{l}0 \\
0 \\
0\end{array}$ & $\begin{array}{l}0 \\
0 \\
0\end{array}$ & $\begin{array}{r}5,000 \\
0\end{array}$ & & & $\begin{array}{l}0 \\
0\end{array}$ & $\begin{array}{c}0 \\
0\end{array}$ & $\begin{array}{l}0 \\
0\end{array}$ & \begin{tabular}{c|c}
0 \\
0
\end{tabular} & $\begin{array}{r}27,000 \\
0\end{array}$ & \\
\hline $\begin{array}{l}\text { FYo0 Liens } \\
\text { Total Monthly Projection }\end{array}$ & $\begin{array}{l}0 \\
0\end{array}$ & $\begin{array}{l}0 \\
0\end{array}$ & $\begin{array}{l}0 \\
0\end{array}$ & $\begin{array}{l}0 \\
0\end{array}$ & $\begin{array}{l}0 \\
0\end{array}$ & $\begin{array}{r}0 \\
5,000\end{array}$ & $\begin{array}{r}0 \\
10,000\end{array}$ & $\begin{array}{r}0 \\
12,000\end{array}$ & $\begin{array}{l}0 \\
0\end{array}$ & $\begin{array}{l}0 \\
0\end{array}$ & $\begin{array}{l}0 \\
0\end{array}$ & $\begin{array}{l}0 \\
0\end{array}$ & $\begin{array}{r}0 \\
27,000\end{array}$ & \\
\hline \begin{tabular}{|l} 
Total Monthly Projection \\
Cumulative Monthly Projection
\end{tabular} & 0 & 0 & 0 & 0 & 0 & $\begin{array}{l}5,000 \\
\end{array}$ & 15,000 & 27,000 & 27,000 & 27,000 & 27,000 & 27,000 & & \\
\hline $\begin{array}{l}\text { Cumulative Costs } \\
\text { Cumblative Costs + Liens }\end{array}$ & $\begin{array}{l}32 \\
32\end{array}$ & $\begin{array}{l}65 \\
65\end{array}$ & $\begin{array}{l}65 \\
65\end{array}$ & & & & & & & & & & & \#DIV/0 \\
\hline
\end{tabular}

70,000 New FY01 Fund
0 Comm. C/O

0 Uncommitted C/O
000 Total FY01 Funding

437,000 New FY01 Fund

0 Uncommitted C/O
497,073 Total FY01 Funding

5,115,000 New FY01 Funds

$1,127,300$ Comm. C/O
24,488 Uncommitted C/O

6,266,788 Total FY01 Funding

3,935,000 New FY01 Funds

140,677 Comm. C/O

4,075,677 Total FY01 Funding

(a)

1,373,000 New FY01 Funds 245,700 Comm. C/I
0 Uncommitted C/O
$1,618,700$ Total FY01 Funding

27,000 New FY01 Funds 0 Comm. C/O
0 Uncommitted C/O
27,000 Total FY01 Funding 
5.2.2.4.5 Can Load

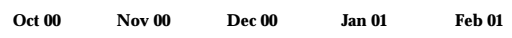

Mar $01 \quad$ Apr $01 \quad$ May $01 \quad$ Jun 01

Jul 01 Aug 01 $\quad$ Sept $01 \quad$ Totals

\begin{tabular}{|c|c|c|c|c|c|c|c|c|c|c|c|c|c|c|}
\hline $\begin{array}{l}\text { lan Loading } \\
\text { WSRC }\end{array}$ & cetoo & . & 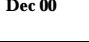 & 然 & tedo & Niar on & Aprov & Nay & 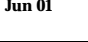 & 年 & Augut & shot & Torals & $\begin{array}{l}\text { Cum. } \\
\text { Var. }\end{array}$ \\
\hline \begin{tabular}{|l|} 
Manpower Projection \\
Major Procurement Projection
\end{tabular} & $\begin{array}{r}40,800 \\
0\end{array}$ & $\begin{array}{r}27,900 \\
0\end{array}$ & $\begin{array}{r}34,400 \\
0\end{array}$ & & & & $\begin{array}{r}29,900 \\
0\end{array}$ & $\begin{array}{r}28,900 \\
0\end{array}$ & $\begin{array}{r}34,400 \\
0\end{array}$ & $\begin{array}{r}28,900 \\
0\end{array}$ & $\begin{array}{r}35,500 \\
0\end{array}$ & $\begin{array}{r}28,000 \\
0\end{array}$ & & \\
\hline $\begin{array}{l}\text { FY00 Liens } \\
\text { Total Monthly Projection }\end{array}$ & $\begin{array}{r}0 \\
40,800\end{array}$ & $\begin{array}{r}0 \\
27,900\end{array}$ & $\begin{array}{r}0 \\
34,400\end{array}$ & $\begin{array}{r}0 \\
27,900\end{array}$ & $\begin{array}{r}0 \\
28,900\end{array}$ & $\begin{array}{r}0 \\
36,500\end{array}$ & $\begin{array}{r}0 \\
29,900\end{array}$ & $\begin{array}{r}0 \\
28,900\end{array}$ & $\begin{array}{r}0 \\
34,400\end{array}$ & $\begin{array}{r}0 \\
28,900\end{array}$ & $\begin{array}{r}0 \\
35,500\end{array}$ & $\begin{array}{r}0 \\
28,000\end{array}$ & $\begin{array}{r}0 \\
382,000\end{array}$ & \\
\hline Cumulative Monthly Projection & 40,800 & 68,700 & 103,100 & 131,000 & 159,900 & 196,400 & 226,300 & 255,200 & 289,600 & 318,500 & 354,000 & 382,000 & & \\
\hline $\begin{array}{l}\text { Cumulative Costs } \\
\text { Cumulative Costs + Liens }\end{array}$ & $\begin{array}{l}41,141 \\
41,141\end{array}$ & $\begin{array}{l}75,622 \\
75,622\end{array}$ & $\begin{array}{l}97,617 \\
97,617\end{array}$ & & & & & & & & & & & $\begin{array}{l}5 \% \\
5 \%\end{array}$ \\
\hline
\end{tabular}

Cumulative Costs
Cumulative Costs + Liens

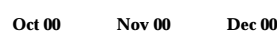

Jan 01 $\quad$ Feb 01 $\quad$ Mar 01 $\quad$ Apr 01

May $01 \quad$ Jun 0

Jul $01 \quad$ Aug 01

Sept 01

Totals

\begin{tabular}{|c|c|c|c|c|c|c|c|c|c|c|c|c|c|c|}
\hline $\begin{array}{l}\text { Can MC\&A } \\
\text { WSRC }\end{array}$ & ocioo & Nov ou & Dec vo & thalive & red or & Maror & Apror & indy or & Juivo & Jurot & Augor & Seprot & 1 totals & $\begin{array}{l}\text { Cum. } \\
\text { Var. }\end{array}$ \\
\hline \begin{tabular}{|l|} 
Manpower Projection \\
\end{tabular} & 4,000 & 7,300 & 8,200 & 7,300 & 12,300 & 14,100 & 11,800 & 11,300 & 9,100 & 7,300 & 9,000 & 7,300 & \begin{tabular}{ll|}
109,000 \\
\end{tabular} & \\
\hline Major Procurement Projection & 0 & 0 & 0 & 0 & 0 & 0 & 0 & 0 & 0 & 0 & 0 & 0 & & \\
\hline FY00 Liens & $\begin{array}{r}0 \\
4000\end{array}$ & $\begin{array}{r}0 \\
7300\end{array}$ & $\begin{array}{r}0 \\
8200\end{array}$ & $\begin{array}{r}0 \\
7300\end{array}$ & $\begin{array}{r}0 \\
12300\end{array}$ & $\begin{array}{r}0 \\
14,100\end{array}$ & $\begin{array}{r}0 \\
11800\end{array}$ & $\begin{array}{r}0 \\
11300\end{array}$ & $\begin{array}{r}0 \\
9100\end{array}$ & $\begin{array}{r}0 \\
7300\end{array}$ & 90 & $\begin{array}{r}0 \\
7300\end{array}$ & reg 0 & \\
\hline$\frac{\text { Total Monthly Projection }}{\text { Cumulative Monthly Projection }}$ & $\frac{4,400}{4,000}$ & $\frac{7,300}{11,300}$ & $\frac{8,200}{19,500}$ & $\frac{7,300}{26,800}$ & $\frac{12,300}{39,100}$ & $\frac{14,100}{53,200}$ & $\frac{11,800}{65,000}$ & $\frac{11,300}{76,300}$ & $\frac{9,1,00}{85,400}$ & $\frac{7,300}{92,700}$ & $\frac{9,000}{101,700}$ & $\frac{7,300}{109,000}$ & & \\
\hline $\begin{array}{l}\text { Cumulative Costs } \\
\end{array}$ & 3,935 & 6,307 & 7,304 & & & & & & & & & & & $63 \%$ \\
\hline Cumulative Costs + Liens & 3,935 & 6,307 & 7,304 & & & & & & & & & & & $63 \%$ \\
\hline
\end{tabular}

5.2.2.4 First Stage Immobilization Total

Oct $00 \quad$ Nov $00 \quad$ Dec 00

Jan 01

Feb 01 Mar 01 Apr 01

May $01 \quad$ Jun 0

Jul 01

Aug 01

Sept 01

Totals

Cum.
Var.

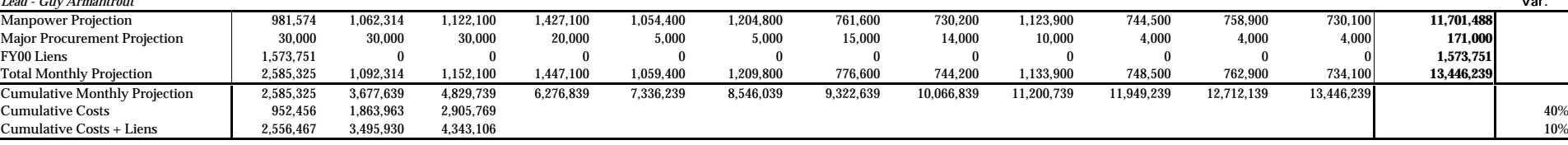

(a)

\begin{tabular}{rrr}
952,456 & $1,863,963$ & $2,2,955,769$ \\
$2,556,467$ & $3,495,930$ & $4,343,106$ \\
\hline
\end{tabular}

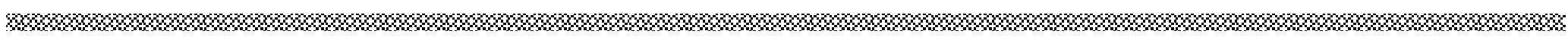

\begin{tabular}{|c|c|c|c|c|c|c|c|c|c|c|c|c|c|c|}
\hline $\begin{array}{l}\text { an in Canister Design and } \\
\text { Assembly } \\
\text { WSRC }\end{array}$ & Oct 00 & Nov 00 & Dec 00 & Jan 01 & Feb 01 & Mar 01 & Apr 01 & May 01 & Jun 01 & Jul 01 & Aug 01 & Sept 01 & Totals & $\begin{array}{l}\text { Cum. } \\
\text { Var. }\end{array}$ \\
\hline Manpower Projection & 26,000 & 16,000 & 16,000 & 16,000 & 16,000 & 16,000 & 16,000 & 16,000 & 16,000 & 16,000 & 16,000 & 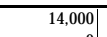 & 200,000 & \\
\hline Major Procurement Projection & 0 & & & 0 & 0 & 0 & 0 & 0 & 0 & 0 & 0 & 0 & & \\
\hline $\begin{array}{l}\text { FY00 Liens } \\
\text { Total Monthly Proiection }\end{array}$ & $\begin{array}{r}0 \\
26000\end{array}$ & $\begin{array}{r}0 \\
16,000\end{array}$ & $\begin{array}{r}0 \\
16,000\end{array}$ & $\begin{array}{r}0 \\
16,000\end{array}$ & $\begin{array}{r}0 \\
16000\end{array}$ & $\begin{array}{r}0 \\
16000\end{array}$ & $\begin{array}{r}0 \\
16,000\end{array}$ & $\begin{array}{r}0 \\
16000\end{array}$ & $\begin{array}{r}0 \\
16,000\end{array}$ & $\begin{array}{r}0 \\
16000\end{array}$ & $\begin{array}{r}0 \\
16000\end{array}$ & $\begin{array}{r}0 \\
14,000\end{array}$ & $\begin{array}{r}200 \\
2000\end{array}$ & \\
\hline$\frac{1 \text { otal Monthy } \text { Crofection }}{\text { Cumulative Monthly Projection }}$ & $\frac{26,000}{26,000}$ & $\frac{16,000}{42,000}$ & $\frac{1,6000}{58,000}$ & $\begin{array}{ll}1,0,000 \\
74,000\end{array}$ & $\frac{16,000}{90,000}$ & $\frac{10,000}{106,000}$ & $\frac{16,000}{122,000}$ & $\frac{16,000}{138,000}$ & $\frac{10,000}{154,000}$ & $\frac{16,000}{170,000}$ & $\frac{16,000}{186,000}$ & $\frac{11,40000}{200,000}$ & & \\
\hline $\begin{array}{l}\text { Cumulative Costs } \\
\text { Cumbative Cots }\end{array}$ & 26,482 & $\begin{array}{l}42,803 \\
48152\end{array}$ & 58,784 & & & & & & & & & & & $-1 \%$ \\
\hline
\end{tabular}

$\begin{array}{lllllllllllllll}\text { 5.2.2.5.1.2 Canister Pour Analysis and Testing } & \text { Oct 00 } & \text { Nov 00 } & \text { Dec 00 } & \text { Jan 01 } & \text { Feb 01 } & \text { Mar 01 } & \text { Apr 01 } & \text { May 01 } & \text { Jun 01 } & \text { Jul 01 } & \text { Aug 01 } & \text { Sept 01 } & \text { Totals } & \text { Cum. }\end{array}$

\begin{tabular}{|c|c|c|c|c|c|c|c|c|c|c|c|c|c|c|}
\hline Manpower Projection & 26,800 & 26,800 & 31,400 & 19,900 & 12,400 & 12,400 & 9,000 & 5,300 & 3,000 & 3,000 & $\overline{0}$ & $\overline{0} \mid$ & & \\
\hline Major Procurement Projection & & & & & 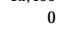 & & & & & & 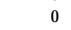 & 0 & & \\
\hline 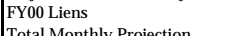 & $\begin{array}{r}43,779 \\
70,790\end{array}$ & $\begin{array}{r}0 \\
26800 \\
-10\end{array}$ & 00 & 0 & 00 & 0 & 0 & 0 & 0 & 0 & 0 & 0 & $\begin{array}{r}43,779 \\
-102707\end{array}$ & \\
\hline Total Monthly Projection & 70,579 & 26,800 & 31,400 & 19,900 & 12,400 & 12,400 & 9,000 & 5,300 & 3,000 & 3,000 & 0 & 0 & 193,779 . & \\
\hline Cumulative Monthly Projection & $\begin{array}{l}70,579 \\
2561\end{array}$ & 97,379 & 128,779 & $\overline{148,679}$ & 161,079 & $\overline{173,479}$ & 182,479 & 187,779 & 190,779 & 193,779 & 193,779 & 193,779 & & \\
\hline $\begin{array}{l}\text { Cumulative Costs } \\
\text { Cumulative Costs + Liens }\end{array}$ & $\begin{array}{l}25,561 \\
67,839\end{array}$ & $\begin{array}{l}42,200 \\
93,479\end{array}$ & $\begin{array}{l}48,294 \\
74,970\end{array}-20$ & & & & & & & & & & & $\%$ \\
\hline
\end{tabular}

5.2.2.5.1.3 Can/Magazine Storage Vault

\begin{tabular}{lll} 
Oct $00 \quad$ Nov $00 \quad$ Dec 00 \\
\hline
\end{tabular}

Jan $01 \quad$ Feb $01 \quad$ Mar $01 \quad$ Apr 01

WSRC
Manpower Projection
Major Procurement Projection
FYoo Liens

FY00 Liens
Total Monthly Projection

Cumulative Monthly Projection

Cumulative Costs
Cumulative Costs + Liens

Dec $00 \quad \mathrm{~J}$

May $01 \quad$ Jur 01

Jun $01 \quad J$

Jul $01 \quad$ Aug 01 Sep 01

Sept $01 \quad$ Totals

cum.

Second Stage Immobilization
Process/Equip Development T

Lead-Tehmau Kan

Manpower Projection

Major Procur
FY00 Liens

Total Monthly Projection

Cumulative Costs
Cumulative Costs + Liens

\begin{tabular}{|c|c|c|c|c|}
\hline 0 & 0 & 0 & 0 & 0 \\
\hline 0 & 0 & 0 & 0 & 0 \\
\hline $\begin{array}{l}0 \\
0\end{array}$ & $\begin{array}{l}0 \\
0\end{array}$ & $\begin{array}{l}0 \\
0 \\
0\end{array}$ & $\begin{array}{l}0 \\
0\end{array}$ & $\begin{array}{l}0 \\
0\end{array}$ \\
\hline$\overline{0}$ & 0 & 0 & 0 & 0 \\
\hline 0 & $\begin{array}{l}613 \\
613\end{array}$ & $\begin{array}{l}613 \\
613\end{array}$ & & \\
\hline
\end{tabular}

8,000
0
0
8,000

\begin{tabular}{rrrr}
8,000 & 8,000 & 8,000 & 8,000 \\
0 & 0 & 0 & 0 \\
0 & 0 & 0 & 0 \\
8,000 & 8,000 & 8,000 & 8,000 \\
\hline 23,000 & 31,000 & 39,000 & 47,000
\end{tabular}

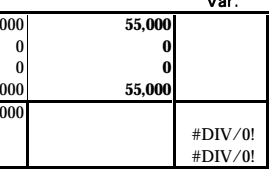

Oct $00 \quad$ Nov $00 \quad$ D

$\begin{array}{llll}\text { Jan } 01 & \text { Feb } 01 \quad \text { Mar } 01 \quad \text { Apr } 01\end{array}$

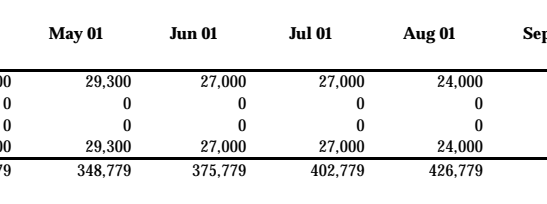

Sept $01 \quad$ Tota

\begin{tabular}{l} 
Cum. \\
Var. \\
\hline
\end{tabular}

\begin{tabular}{|c|c|c|c|c|c|c|c|c|c|c|c|c|}
\hline 52,800 & 42,800 & 47,400 & 35,900 & 28,400 & 35,400 & 33,000 & 29,300 & 27,000 & 27,000 & 24,000 & 22,000 & 405,000 \\
\hline & & & & & & & 0 & 0 & 0 & $\begin{aligned} 24,000 \\
0\end{aligned}$ & $\begin{array}{r}2,, 000 \\
0\end{array}$ & \\
\hline 43,779 & & 0 & 0 & 0 & 0 & 0 & 0 & 0 & 0 & 0 & 0 & 43,779 \\
\hline$\frac{96,579}{96,79}$ & $\frac{42,280}{139,379}$ & $\begin{array}{l}48,460 \\
186,779\end{array}$ & $\begin{array}{l}32,2,600 \\
22,679\end{array}$ & $\frac{28,400}{251,079}$ & $\begin{array}{r}32,46,479 \\
2\end{array}$ & 33,000 & $\begin{array}{r}29,300 \\
348,779\end{array}$ & $\begin{array}{l}3,000 \\
75,779\end{array}$ & $\begin{array}{l}27,000 \\
402,779\end{array}$ & $\begin{array}{r}42,000 \\
426,779\end{array}$ & $\frac{22,0,00 \mid}{448,770}$ & 448,779 \\
\hline
\end{tabular}

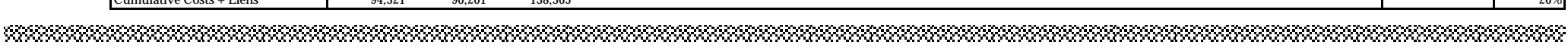

382,000 New FY01 Funds

$\begin{aligned} 0 & \text { Uncommitted C/O } \\ 382,000 \text { Total FY01 Funding } & \end{aligned}$

109,000 New FY01 Funds

0 Uncommitted C/O
109,000 Total $\mathrm{FY01}$ Funding

11,848,000 New FY01 Funds

24,488 Uncommitted C/O
$13,446,238$ Total FY01 Funding

43,770 Uncommitted C/O
193,779 Total FY01 Funding

200,000 New FY01 Fund

0 Comm. C/O
0 Uncommitted C/O
200,000 Total FYo1 Funding

55,000 New FY01 Funds
0 Comm. C/O

0 Comm. C/O
0 Uncommitted C/O
55,000 Total FY01 Funding

405,000 New FY01 Funds

43,779 Comm. C/O

0 Uncommitted C/O
448,779 Total FY01 Funding 
\begin{tabular}{ll} 
5.2.3.1.1 & $\begin{array}{l}\text { Radiation-Damaged Sample } \\
\text { Synthesis }\end{array}$ \\
\hline
\end{tabular} Oct $00 \quad$ Nov $00 \quad$ Dec $00 \quad$ Jan $01 \quad$ Feb 01 Mar $01 \quad$ Apr $01 \quad$ May $01 \quad$ Jun 01

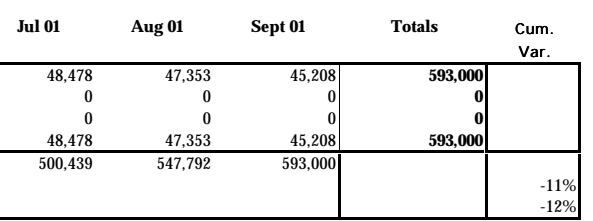

\begin{tabular}{|c|c|c|c|c|c|c|c|c|c|c|c|c|c|c|}
\hline Manpower Projection & 33,212 & 38,516 & 42,024 & 44,780 & 52,021 & 59,834 & 64,213 & 65,151 & 52,210 & 48,478 & & & & Var. \\
\hline Major Procurement Projection & 0 & 0 & 0 & 0 & 0 & 0 & 0 & 0 & 0 & 0 & 0 & 0 & 0 & \\
\hline $\begin{array}{l}\text { FYoo Liens } \\
\text { Total Monthly Projection }\end{array}$ & $\begin{array}{r}0 \\
33,212\end{array}$ & 38,00 & $\begin{array}{r}0 \\
42,024\end{array}$ & $\begin{array}{r}0 \\
44,780 \\
-10\end{array}$ & $\begin{array}{r}0 \\
52,021 \\
\end{array}$ & $\begin{aligned} 0 \\
59,834\end{aligned}$ & $\begin{array}{r}0 \\
64,213\end{array}$ & $\begin{array}{r}0 \\
65,151\end{array}$ & $\begin{array}{r}0 \\
52,210 \\
\end{array}$ & $\begin{array}{r}0 \\
48,478\end{array}$ & $\begin{array}{r}0 \\
47,353 \\
\end{array}$ & $\begin{array}{r}0 \\
45,208\end{array}$ & $\begin{array}{r}0 \\
593,000\end{array}$ & \\
\hline Cumulative Monthly Projection & 33,212 & 71,728 & 113,752 & 158,532 & 210,553 & 270,387 & 334,600 & 399,751 & 451,961 & 500,439 & 547,792 & 593,000 & & \\
\hline $\begin{array}{l}\text { Cumulative Costs } \\
\text { Cumulative Costs + Liens }\end{array}$ & $\begin{array}{l}33,212 \\
33,212\end{array}$ & 66,671 & $\begin{array}{l}125,729 \\
12688\end{array}$ & & & & & & & & & & & $-11 \%$ \\
\hline
\end{tabular}

Short-Term Corrosion Tests

\begin{tabular}{|c|c|c|c|c|c|c|c|c|c|c|c|c|c|c|}
\hline $\begin{array}{l}\text { Short-Term Corrosion Tests } \\
A N L\end{array}$ & Oct 00 & Nov 00 & Dec 00 & $\operatorname{Jan} 01$ & Feb 01 & Mar 01 & Apr 01 & May 01 & Jun 01 & Jul 01 & Aug 01 & Sept 01 & Totals & $\begin{array}{l}\text { Cum. } \\
\text { Var. }\end{array}$ \\
\hline Manpower Projection & 10,000 & 15,000 & 8,000 & 15,000 & 15,000 & 10,000 & 10,000 & 10,000 & 10,000 & 8,000 & 7,000 & 6,000 & 124,000 & \\
\hline Major Procurement Projection & & & & & & & & & 0 & & & & & \\
\hline $\begin{array}{l}\text { FY00 Liens } \\
\text { Total Monthly Projection }\end{array}$ & $\begin{array}{r}0 \\
10,000\end{array}$ & $\begin{array}{r}0 \\
15,000\end{array}$ & $\begin{array}{r}0 \\
8,000\end{array}$ & $\begin{array}{r}0 \\
15,000\end{array}$ & $\begin{array}{r}0 \\
15,000\end{array}$ & $\begin{array}{r}0 \\
10,000\end{array}$ & $\begin{array}{r}0 \\
10,000\end{array}$ & $\begin{array}{r}0 \\
1000\end{array}$ & $\begin{array}{r}0 \\
1000\end{array}$ & $\begin{aligned} 0 \\
8000\end{aligned}$ & $\begin{array}{r}0 \\
7000\end{array}$ & $\begin{array}{r}0 \\
6000\end{array}$ & $\begin{array}{r}124000 \\
12-12\end{array}$ & \\
\hline Cumulative Mo & 10,000 & 25,000 & 33,000 & $\frac{10,000}{48,000}$ & $\frac{10,000}{63,000}$ & 73,000 & 83,000 & 93,000 & $\frac{1,03,000}{103}$ & 111,000 & 118,000 & 124,000 & & \\
\hline $\begin{array}{l}\text { Cumulative Co. } \\
\text { Co }\end{array}$ & 23,200 & 40,000 & 57,200 & & & & & & & & & & & $73 \%$ \\
\hline Cumulative Costs + Liens & 23,2000 & 40,000 & 57,200 & & & & & & & & & & & $-73 \%$ \\
\hline
\end{tabular}

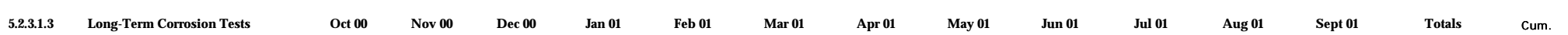

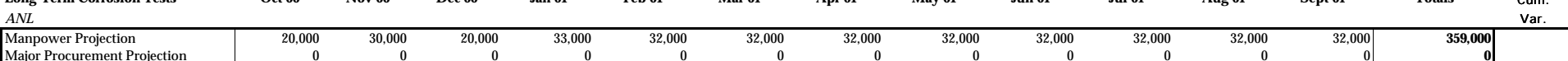
Major Procur
FYoo Liens Total Monthly Projection Cumulative Costs Cumulative Costs + Liens

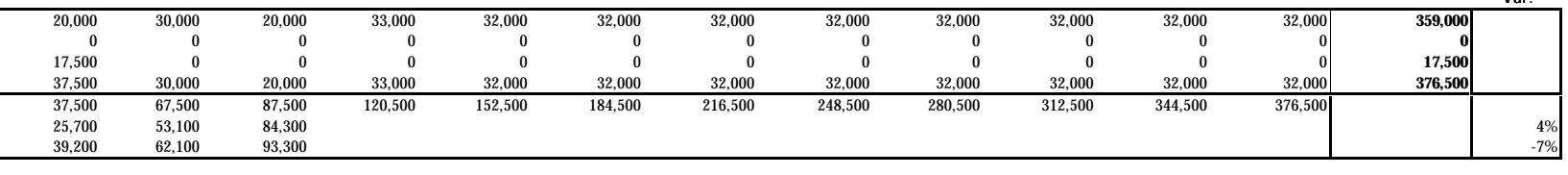

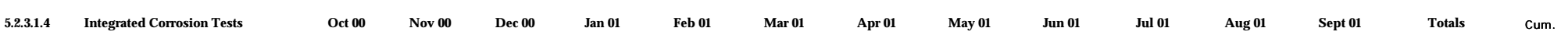

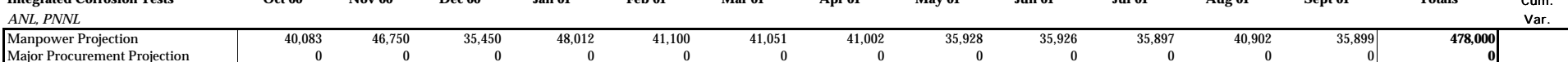
Najor Procurement Projection
FYoo Lies
Total Monthly Projection Total Monthly Projection Cumulative Costs
Cumulative Costs + Lien

\begin{tabular}{|c|c|c|c|c|c|c|c|c|c|c|c|c|c|}
\hline 40,083 & 46750 & 35450 & 48012 & 41,100 & 41051 & 41,002 & 35928 & 35926 & 35897 & 40902 & 358991 & 478,000 & \\
\hline 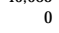 & 0 & 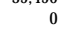 & 0 & 0 & 0 & 02 & 20 & 0 & 0 & 0 & 0 & & \\
\hline $\begin{array}{l}16,211 \\
56294\end{array}$ & $\begin{array}{r}0 \\
46750\end{array}$ & $\begin{array}{r}0 \\
35,450\end{array}$ & $\begin{array}{r}0 \\
48.012\end{array}$ & $\begin{array}{r}0 \\
41,00\end{array}$ & $\begin{array}{r}0 \\
41051\end{array}$ & $\begin{array}{r}0 \\
41002\end{array}$ & $\begin{array}{r}0 \\
35928\end{array}$ & $\begin{array}{r}0 \\
35926\end{array}$ & $\begin{array}{r}0 \\
33899\end{array}$ & $\begin{array}{r}0 \\
40902\end{array}$ & $\begin{array}{r}0 \\
35899\end{array}$ & $\begin{array}{r}16,211 \\
\end{array}$ & \\
\hline 56,294 & 103,044 & 138,494 & 186,506 & 227,606 & 268,657 & 309,659 & 345,587 & 381,513 & 417,410 & 458,312 & $494,211 \mid$ & & \\
\hline $\begin{array}{l}38,313 \\
53299\end{array}$ & $\begin{array}{l}69,973 \\
881143\end{array}$ & $\begin{array}{l}116,846 \\
11277755\end{array}$ & & & & & & & & & & & $16 \%$ \\
\hline
\end{tabular}

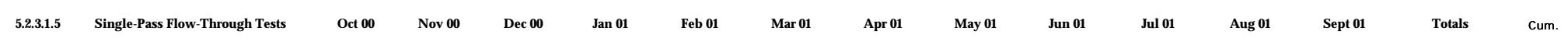

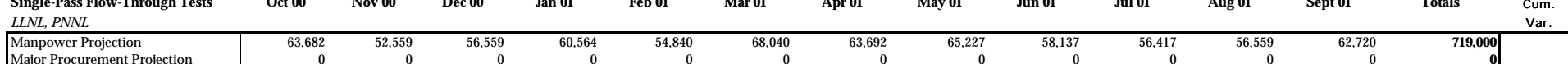
Major Procurement Prop
FYoo Liens Total Monthly Projection Cumulative Costs
Cumulative Costs + Lien

\begin{tabular}{|c|c|c|c|c|c|c|c|c|c|c|c|c|c|}
\hline 63,682 & 52,559 & 56,559 & 60,564 & 54,840 & 68,040 & 63,692 & 65,227 & 58,137 & 56,417 & 56,559 & 62,720 & 719,000 & \\
\hline $\begin{array}{r}0 \\
15,478\end{array}$ & & $\begin{array}{l}0 \\
0\end{array}$ & & $\begin{array}{l}0 \\
0\end{array}$ & $\begin{array}{l}0 \\
0\end{array}$ & $\begin{array}{l}0 \\
0 \\
0\end{array}$ & $\begin{array}{l}0 \\
0\end{array}$ & $\begin{array}{l}0 \\
0 \\
0\end{array}$ & $\begin{array}{l}0 \\
0\end{array}$ & $\begin{array}{l}0 \\
0\end{array}$ & $\begin{array}{l}0 \\
0\end{array} \mid$ & $\begin{array}{r}0 \\
15,478\end{array}$ & \\
\hline 79,160 & 52,559 & 56,559 & 60,564 & 54,840 & 68,040 & $\begin{array}{l}63,692 \\
\end{array}$ & $\begin{array}{r}65,227 \\
\end{array}$ & $\begin{array}{r}58,137 \\
\end{array}$ & 56,417 & $\begin{array}{r}56,559 \\
\end{array}$ & $\begin{array}{l}62,720 \\
\end{array}$ & $\begin{array}{r}153,478 \\
734,48 \\
\end{array}$ & \\
\hline $\begin{array}{l}79,160 \\
63,485 \\
67\end{array}$ & $\begin{array}{l}131,720 \\
109,312\end{array}$ & $\begin{array}{l}188,279 \\
189,264\end{array}$ & 248,843 & 303,684 & 371,724 & 435,416 & \begin{tabular}{l|l}
500,644 \\
\end{tabular} & 558,781 & 615,198 & 671,758 & 734,478 & & $-1 \%$ \\
\hline
\end{tabular}

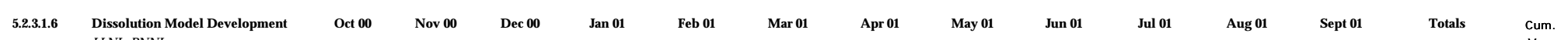

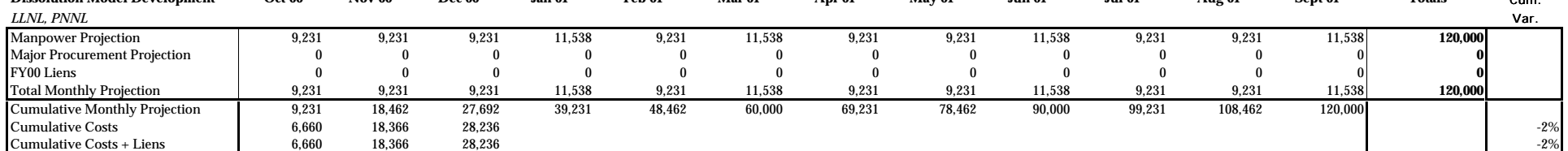

593,000 New FY01 Funds
0 Comm. C/O 0 Uncommitted C/O
3.,000 Total FY01 Funding

124,000 New FY01 Funds
0 Comm. C/O 0 Uncommitted C/O
4., 000 Total FY01 Funding

359,000 New FY01 Funds
17,500 Comm. C/O 0 Uncommitted C/O
376,500 Total FY01 Funding

478,000 New FY01 Funds
16,211 Comm. C/O 1 Uncommitted C/O
494,211 Total FY01 Funding

719,000 New FY01 Funds
15,478 Comm. C/O 0 Uncommitted C/O
734,478 Total FY01 Funding

Form Performance

Jan $01 \quad \quad$ Feb 01 May $01 \quad$ Ju

\begin{tabular}{llll} 
Jul $01 \quad$ Aug 01 & Sep \\
\hline
\end{tabular}

Cum.

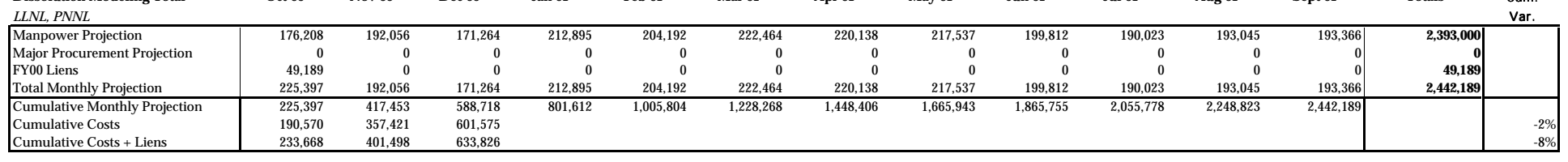
49,189 Comm. C/O
0 Uncommitted C/O

2,442,189 Total FY01 Funding

Form Qualification and Repository
Interaction

$L L N L, W S R C, A N L, P N N L$

Manpower Projection
Major Procurement Projection

Major Procu
FYOo Liens

$\begin{array}{rrrrrrr}\text { Oct 00 } & \text { Nov 00 } & \text { Dec 00 } & \text { Jan 01 } & \text { Feb 01 } & \text { Mar 01 } & \text { Apr 01 }\end{array}$

May $01 \quad J u$

\begin{tabular}{llll} 
Jul 01 & Aug 01 & Sept 01 & Totals \\
\hline
\end{tabular}

cum. Cumulative Monthly Projectio Cumulative Costs
Cumulative Costs + Liens

$\begin{array}{rrr}52,285 & 51,972 & \\ 0 & 0 \\ 40 & 0 & \\ 40 & 51,972 & \\ 52,325 & \\ 52,325 & 104,298 & 15,78 \\ 77,864 & 136,497 & 177,02 \\ 77,904 & 136,537 & \end{array}$
\begin{tabular}{rr}
0 & \\
48,483 & 49,785 \\
\hline 152,781 & 202,566
\end{tabular} \begin{tabular}{rrrr} 
& 0 & 0 & 0 \\
49,785 & 0 & 0 & 0 \\
\hline 54292 & 61,654 & 51273
\end{tabular} $\begin{array}{r}57,483 \\ 0 \\ 0 \\ 57,483 \\ \hline 427,269\end{array}$ $\begin{array}{r}57,892 \\ 0 \\ 0 \\ 57,892 \\ \hline 485,162\end{array}$ $\begin{array}{r}50,618 \\ 0 \\ 0 \\ 50,618 \\ \hline 535,780\end{array}$ 62,554
0
0
62,554
598,334 \begin{tabular}{|r|r|r|} 
& & Var. \\
81,706 & 680,000 & \\
0 & 0 & \\
0 & 40 & \\
81,706 & 680,040 & \\
\hline 680,040 & & \\
& & $-16 \%$ \\
\hline
\end{tabular} 


\begin{tabular}{|c|c|c|c|c|c|c|c|c|c|c|c|c|c|c|}
\hline $\begin{array}{l}\text { D\&T Form Qualification Total } \\
\text { Lead - Henry Shaw }\end{array}$ & Oct 00 & Nov 00 & Dec 00 & Jan 01 & Feb 01 & Mar 01 & Apr 01 & May 01 & Jun 01 & Jul 01 & Aug 01 & Sept 01 & Totals & $\begin{array}{l}\text { Cum. } \\
\text { var. }\end{array}$ \\
\hline $\begin{array}{l}\text { Manpower Projection } \\
\text { Major Procurement Projection }\end{array}$ & $\begin{aligned} 228,494 \\
0\end{aligned}$ & $\begin{aligned} 244,029 \\
0\end{aligned}$ & $\begin{aligned} 219,748 \\
0\end{aligned}$ & $\begin{array}{ll}262,680 \\
0\end{array}$ & $\begin{aligned} 258,485 \\
0\end{aligned}$ & $\begin{array}{ll}284,118 \\
0\end{array}$ & $\begin{aligned} 271,412 \\
0\end{aligned}$ & $\begin{array}{ll}275,021 \\
0\end{array}$ & $\begin{aligned} 257,704 \\
0\end{aligned}$ & $\begin{array}{l}240,642 \\
0\end{array}$ & $\begin{aligned} 255,599 \\
0\end{aligned}$ & \begin{tabular}{rl|}
275,072 \\
0
\end{tabular} & \begin{tabular}{ll|}
$3,073,000$ \\
0
\end{tabular} & \\
\hline FYOO Liens & 49,229 & & & & & 0 & 0 & 0 & 0 & & 0 & 0 & 49,229 & \\
\hline Total Monthly Projection & 277,723 & 244,029 & 219,748 & 262,680 & 258,485 & 284,118 & 271,412 & 275,021 & 257,704 & 240,642 & 255,599 & 275,072 & $3,122,229$ & \\
\hline \begin{tabular}{l|} 
Cumulative Monthly Projection \\
Cumulative Costs
\end{tabular} & $\begin{array}{l}277,723 \\
268,434\end{array}$ & $\begin{array}{l}521,751 \\
493,918\end{array}$ & $\begin{array}{l}741,499 \\
778,597\end{array}$ & $\begin{array}{ll}1,004,178 \\
\end{array}$ & $1,262,663$ & $1,546,781$ & $1,818,192$ & $2,093,213$ & $2,350,917$ & $2,591,558$ & $2,847,157$ & $3,122,229$ & & \\
\hline 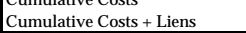 & 311,572 & 538,035 & 810,888 & & & & & & & & & & & \\
\hline
\end{tabular}

3,073,000 New FY01 Fund

49,229 Comm. C/O
0 Uncommitted C/O

Cumulative Costs
Cumulative Costs + Liens

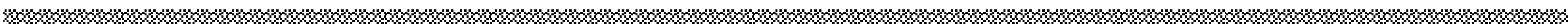

5.3.1 D\&T Technology Transfer

\begin{tabular}{|c|c|c|c|c|c|c|c|c|c|c|c|c|c|c|}
\hline $\begin{array}{l}\text { D\&T Technology Transfer } \\
\text { Lead - Kent Sullivan }\end{array}$ & octo & 0000 & (2) & 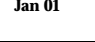 & terout & Narot & ( & Not & (5) & 我 & Augor & 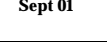 & Torals & $\begin{array}{l}\text { Cum. } \\
\text { Var. }\end{array}$ \\
\hline Manpower Projection & 0 & 0 & 5,000 & 5,000 & 60,000 & 100,000 & 80,000 & 0 & 0 & 0 & 0 & 0 & 250,000 & \\
\hline Major Procurement Projection & 0 & 0 & 0 & 0 & 0 & & 0 & 0 & 0 & 0 & 0 & 0 & & \\
\hline $\mid \begin{array}{l}\text { FY00 Liens } \\
\text { Total Ionthly Projection }\end{array}$ & 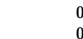 & $\begin{array}{c}0 \\
0 \\
0\end{array}$ & $\begin{array}{r}0 \\
5,000\end{array}$ & $\begin{array}{r}0 \\
5,000\end{array}$ & $\begin{array}{r}0 \\
60.000\end{array}$ & $\begin{array}{r}0 \\
100,000\end{array}$ & $\begin{aligned} 0 \\
80,000\end{aligned}$ & $\begin{array}{l}0 \\
0\end{array}$ & $\begin{array}{l}0 \\
0\end{array}$ & $\begin{array}{l}0 \\
0\end{array}$ & $\begin{array}{l}0 \\
0\end{array}$ & $\begin{array}{l}0 \\
0 \\
0\end{array}$ & $\left.\begin{array}{rl}0 & 0 \\
250,000\end{array}\right]$ & \\
\hline Cumulative Monthly Projection & 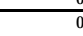 & 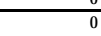 & $\frac{3,000}{5,000}$ & $\frac{10,000}{10,000}$ & 70,000 & $10,0,000$ & 250,000 & 250,000 & 250,000 & 250,000 & 250,000 & 250,000 & & \\
\hline Cumulative Costs & 0 & 613 & 2,841 & & & & & & & & & & & $43 \%$ \\
\hline Cumulative Costs + Liens & & & 2,841 & & & & & & & & & & & $43 \%$ \\
\hline
\end{tabular}

250,000 New FY01 Funds 0 Uncommitted C/O

Allabs

All Labs Immobilization and
Associated Processing Total

\section{Feb 01}

Mar $01 \quad$ Apr 01

May $01 \quad$ Jun 01

Jul $01 \quad$ Aug $01 \quad$ Sept 01

Totals Cum

\begin{tabular}{|c|c|c|c|c|c|c|c|c|c|c|c|c|c|c|}
\hline Manpower Projection & & & & & & & & & & & & & & var. \\
\hline $\begin{array}{l}\text { Majojor Procurement Projection } \\
\text { Major }\end{array}$ & $\begin{array}{r}2,4,41,41 \\
30,000 \\
2030250\end{array}$ & $\begin{aligned}2,099,7+4) \\
30,000\end{aligned}$ & $\begin{array}{r}2,500,3030 \\
30,000\end{array}$ & $\begin{array}{l}3,000,000 \\
240,000\end{array}$ & $\begin{array}{r}2,4 / 2,012 \\
5,000\end{array}$ & $\begin{array}{r}2,192,4) \\
5,000\end{array}$ & $\begin{array}{r}2,009,2 / 4 \\
15,000\end{array}$ & $\begin{array}{r}1,142,102 \\
14,000\end{array}$ & $\begin{aligned} 2,0,05,000 \\
10,000\end{aligned}$ & $\begin{aligned} 1,200 \\
4,000\end{aligned}$ & 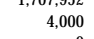 & $\left.\begin{array}{r}1,120,0000 \\
4,000\end{array}\right]$ & $\begin{array}{r}20,25,3,000 \\
391,000\end{array}$ & \\
\hline FYoo Liens & $2,433,052$ & & & & 0 & & & 0 & 0 & 0 & 0 & & $2,433,052$ & \\
\hline otal Monthly Projection & $4,884,522$ & $2,927,544$ & $2,415,536$ & $3,298,518$ & $2,477,612$ & $2,734,249$ & $2,024,274$ & $1,736,152$ & $2,105,066$ & $1,707,507$ & $1,711,952$ & $1,730,608$ & $29,753,540$ & \\
\hline \begin{tabular}{l|} 
Cumulative Monthly Projection \\
Cumulative Costs
\end{tabular} & $\begin{array}{l}4,884,522 \\
2,092,470\end{array}$ & $\begin{array}{l}7,812,066 \\
4,746,925\end{array}$ & $\begin{aligned} 10,227,602 \\
7,119,273\end{aligned}$ & $13,526,120$ & $16,003,732$ & $18,737,981$ & $20,762,255$ & $22,498,407$ & $24,603,473$ & $26,310,980$ & $28,022,932$ & $29,753,540$ & & $\%$ \\
\hline $\begin{array}{l}\text { Cumbuative Costs } \\
\text { Cumulative Costs + Liens }\end{array}$ & $\begin{array}{l}2,0,92,4,40 \\
4,910,516\end{array}$ & $\begin{array}{l}4,44,6,293 \\
7,631,693\end{array}$ & $9,950,348$ & & & & & & & & & & & $3 \%$ \\
\hline
\end{tabular}

27,296,000 New FY01 Funds Total FY01 All Labs
Tans 
LLNL - Immobilization

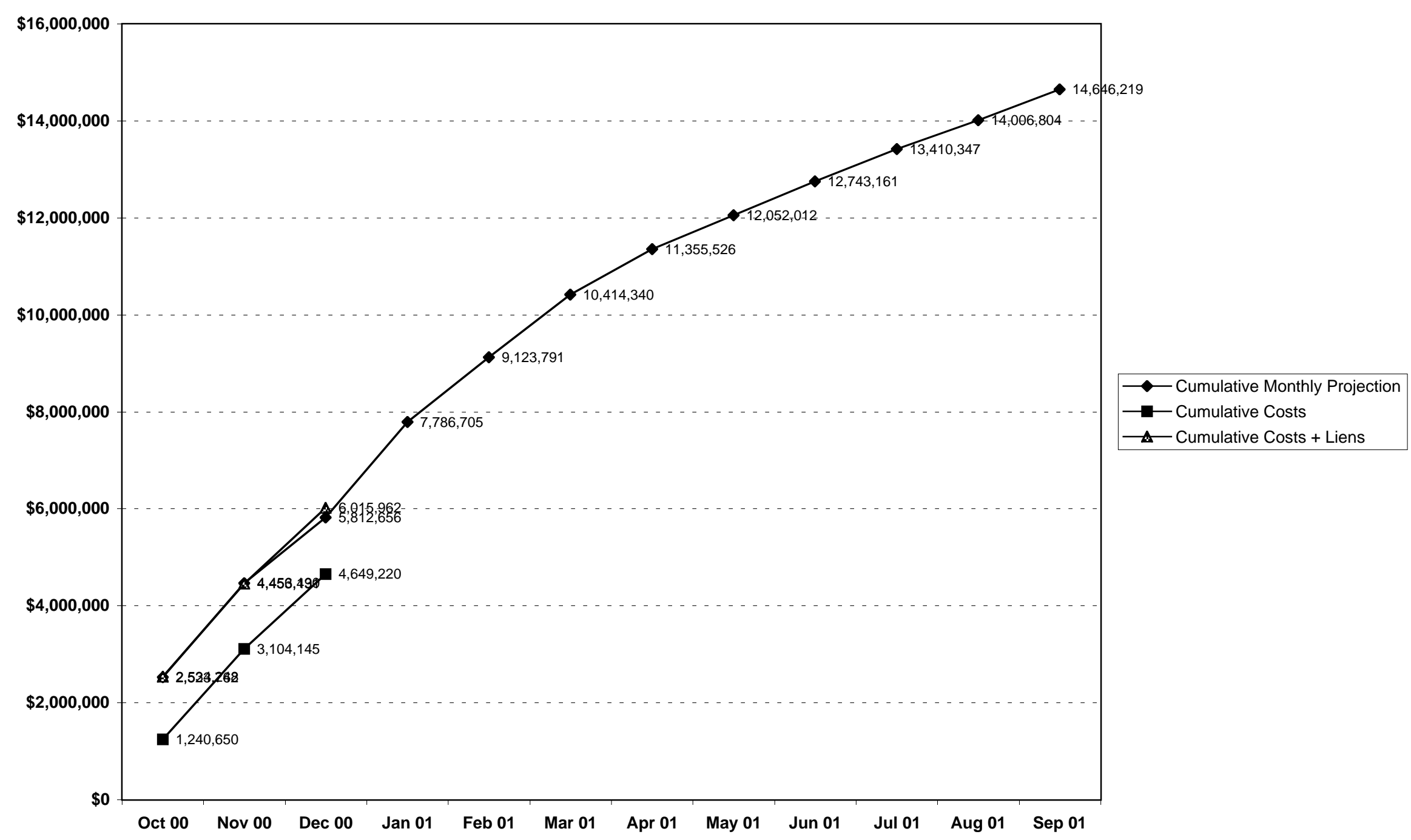


LLNL FY01 Spend Plan

5.1.2 DOCDR Total

\begin{tabular}{|c|c|c|c|c|c|c|c|c|c|c|c|c|c|c|}
\hline $\begin{array}{l}\text { DOCDR Total } \\
\text { Lead -Al Disabatino }\end{array}$ & Oct 00 & Nov 00 & Dec 00 & Jan 01 & Feb 01 & Mar 01 & Apr 01 & May 01 & Jun 01 & Jul 01 & Aug 01 & Sep 01 & Totals & $\begin{array}{l}\text { Cum. } \\
\text { Var. }\end{array}$ \\
\hline \begin{tabular}{|l|} 
Manpower Projection \\
Major Procurement Projection \\
FY00 Liens
\end{tabular} & $\begin{array}{r}15,000 \\
271,970\end{array}$ & 15,000 & & & & & & & & & & & $\begin{array}{r}30,000 \\
0 \\
271,970\end{array}$ & \\
\hline Total Monthly Projection & 286,970 & 15,000 & 0 & 0 & 0 & 0 & 0 & 0 & 0 & 0 & 0 & 0 & 301,970 & \\
\hline \begin{tabular}{|l|} 
Cumulative Monthly Projection \\
Cumulative Costs
\end{tabular} & $\begin{array}{l}286,970 \\
109,515\end{array}$ & $\begin{array}{l}301,970 \\
150,110\end{array}$ & $\begin{array}{l}301,970 \\
240,181\end{array}$ & 301,970 & 301,970 & 301,970 & 301,970 & 301,970 & 301,970 & 301,970 & 301,970 & 301,970 & & $20 \%$ \\
\hline Cumulative Costs + Liens & 285,711 & 246,732 & 339,997 & & & & & & & & & & & $-13 \%$ \\
\hline
\end{tabular}

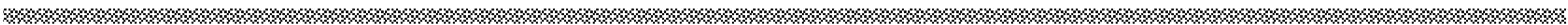

5.2.1.1 Technical Project Office

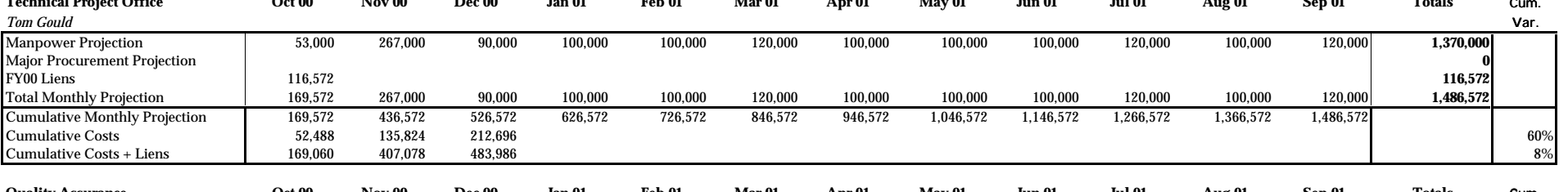

5.2.1.2

Quality Assurance

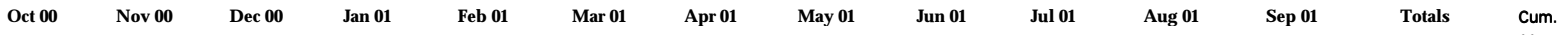

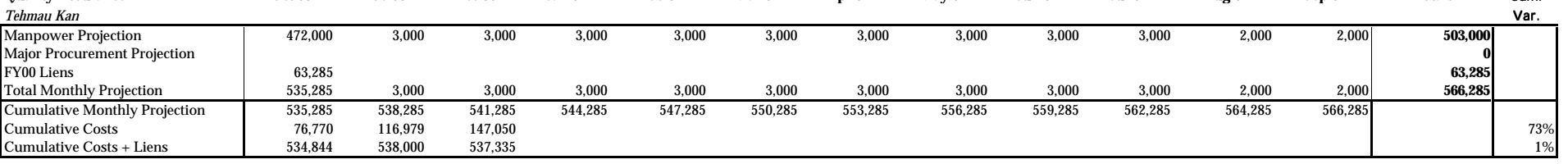

5.2.1.

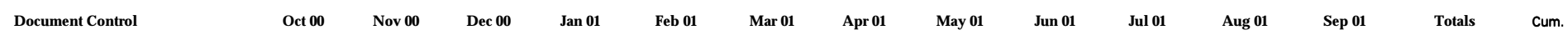

\begin{tabular}{|c|c|c|c|c|c|c|c|c|c|c|c|c|c|c|}
\hline $\begin{array}{l}\text { Document Control } \\
\text { Al Disababtino }\end{array}$ & 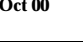 & 年 & 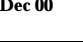 & 年 & Tet & . & Aprol & Nidy or & Junot & 正 & Aug ot & sepor & Tots & $\begin{array}{l}\text { Cum. } \\
\text { Var. }\end{array}$ \\
\hline \begin{tabular}{|l|} 
Manpower Projection \\
Major Procurement Projection \\
FYon Liens
\end{tabular} & $\begin{array}{r}380 \\
164,100\end{array}$ & 20,000 & 20,000 & 20,000 & 20,000 & 20,000 & 20,000 & 20,000 & 20,000 & 20,000 & 20,000 & \begin{tabular}{|c|}
19,620 \\
\end{tabular} & $\begin{array}{r}220,000 \\
0 \\
164,100\end{array}$ & \\
\hline Total Monthly Projection & 164,480 & 20,000 & 20,000 & 20,000 & 20,000 & 20,000 & 20,000 & 20,000 & 20,000 & 20,000 & 20,000 & 19,620 & 384,100 & \\
\hline $\begin{array}{l}\text { Cumulative Monthly Projection } \\
\text { Cumulative Costs }\end{array}$ & $\begin{array}{r}164,480 \\
380 \\
164,405\end{array}$ & $\begin{array}{r}184,480 \\
22,19 \\
16876\end{array}$ & $\begin{aligned} 204,480 \\
19,727 \\
167081\end{aligned}$ & 224,480 & 244,480 & 264,480 & 284,480 & 304,480 & 324,480 & 344,480 & 364,480 & $384,100 \mid$ & & $90 \%$ \\
\hline
\end{tabular}

63,285 Comm. CiO

566,285 Total FY01 Funding

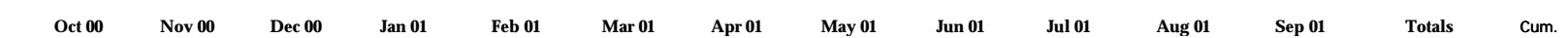

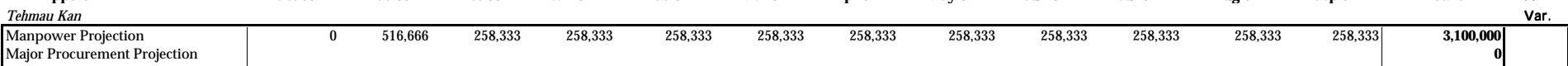

FYoo Liens

Cumulative Monthly Projection

Cumulative Costs + Liens

\begin{tabular}{l}
0 \\
\\
0 \\
0 \\
0 \\
0 \\
\hline
\end{tabular}

5.2.1 D\&T Program Management Tota

58,333
55,000
48,851
98,851

258,333

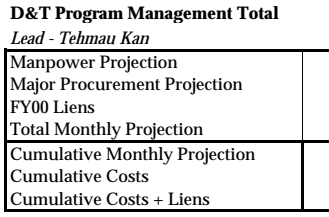

Nov 00

Dec $00 \quad$ Jan 0

Feb 01

\begin{tabular}{rrrrrrr}
258,333 & 258,333 & 258,333 & 258,333 & 258,333 & 258,333 & 258,33 \\
\hline $1,550,000$ & $1,808,333$ & $2,066,666$ & $2,325,000$ & $2,583,333$ & $2,841,666$
\end{tabular}

\begin{tabular}{rr}
258, \\
3,100 \\
\hline 1,660
\end{tabular}

\begin{tabular}{l|l|} 
& \\
& $3,100,000$ \\
\hline, 000 & \\
\end{tabular}

3,100,000

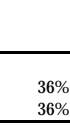

3,100,000 New FY01 Funds Uncommitted $\mathrm{C} / \mathrm{O}$

220,000 New FY01 Funds Uncommitted C/O
384,100 Total FY01 Funding

Cumulative Costs + Liens

$\begin{array}{rr}525,380 & \\ 0 & 8 \\ 343,957 & \\ 869,337 & 8 \\ 869,337 & 1,66606 \\ 129,38 & \end{array}$

$\begin{array}{rrr} & & \\ 6,666 & 371,333 & 381,333 \\ 0 & 0 & \\ 0 & 0 & \\ 06,666 & 371,333 & 381,33 \\ 1,76,003 & 2,047,337 & 2,428,67 \\ \end{array}$

Mar $01 \quad$ Apr 01

May $01 \quad$ Jun 01

Jul $01 \quad$ Aug 0

$01 \quad$ Sep 01

Totals

Cum. 3,100,000 Total FY01 Funding

« 
LLNL FY01 Spend Plan

\begin{tabular}{|c|c|c|c|c|c|c|c|c|c|c|c|c|c|c|c|}
\hline 5.2.2.2.1. & $\begin{array}{l}\text { Feed Materials Characterization and } \\
\text { Blending } \\
\text { Al DiSabatino }\end{array}$ & Oct 00 & Nov 00 & Dec 00 & Jan 01 & Feb 01 & Mar 01 & Apr 01 & May 01 & Jun 01 & Jul 01 & Aug 01 & Sep 01 & Totals & $\begin{array}{l}\text { Cum. } \\
\text { var. }\end{array}$ \\
\hline & $\begin{array}{l}\text { Manpower Projection } \\
\text { Major Procurement Projection } \\
\text { FYoo Liens } \\
\text { Total Monthly Projection }\end{array}$ & $\begin{array}{r}31,120 \\
1,045 \\
32,165\end{array}$ & $\begin{array}{l}22,000 \\
22,000\end{array}$ & $\begin{array}{r}21,880 \\
21,880\end{array}$ & 0 & 0 & 0 & 0 & 0 & 0 & 0 & 0 & & \begin{tabular}{r|}
75,000 \\
0 \\
1,045 \\
76,045
\end{tabular} & \\
\hline & Cumulative Monthly Projection & 32,165 & 54,165 & $\frac{2,0005}{76,045}$ & 76,045 & 76,045 & 76,045 & 76,045 & 76,045 & 76,045 & 76,045 & 76,045 & $76,045 \mid$ & & \\
\hline & $\begin{array}{l}\text { Cumulative Costs } \\
\text { Cumulative Costs + Liens }\end{array}$ & $\begin{array}{l}31,120 \\
32,165\end{array}$ & $\begin{array}{l}69,546 \\
70,591\end{array}$ & $\begin{array}{l}74,776 \\
75,821\end{array}$ & & & & & & & & & & & $\begin{array}{l}2 \% \\
0 \%\end{array}$ \\
\hline \multirow[t]{4}{*}{ 5.2.2.1.2. } & $\begin{array}{l}\text { Proliferation Resistance } \\
\text { Al Disabatino }\end{array}$ & Oct 00 & Nov 00 & Dec 00 & Jan 01 & Feb 01 & Mar 01 & Apr 01 & May 01 & Jun 01 & Jul 01 & Aug 01 & Sep 01 & Totals & $\begin{array}{l}\text { Cum. } \\
\text { Var. }\end{array}$ \\
\hline & \begin{tabular}{|l|} 
Manpower Projection \\
Major Procurement Projection \\
FYoo Liens \\
Total Monthly Projection
\end{tabular} & 0 & 0 & 10,000 & $\begin{array}{r}20,000 \\
120,000 \\
140,000\end{array}$ & $\begin{array}{l}10,000 \\
10,000\end{array}$ & $\begin{array}{l}10,000 \\
10,000\end{array}$ & $\begin{array}{l}5,000 \\
5,000\end{array}$ & 5,000 & 5,000 & 5,000 & $\begin{array}{l}5,000 \\
5,000\end{array}$ & 5,000 & $\begin{array}{r}80,000 \\
120,000 \\
0 \\
200,000\end{array}$ & \\
\hline & Cumulative Monthly Projection & 0 & 0 & $\frac{10,00}{10,000}$ & 150,000 & $\frac{16,000}{160,000}$ & 170,000 & 175,000 & 180,000 & 185,000 & 190,000 & 195,000 & $200,000 \mid$ & & \\
\hline & $\begin{array}{l}\text { Cumulative Costs } \\
\text { Cumulative Costs + Liens }\end{array}$ & $\begin{array}{l}0 \\
0\end{array}$ & $\begin{array}{l}0 \\
0\end{array}$ & $\begin{array}{l}0 \\
0\end{array}$ & & & & & & & & & & & $\begin{array}{l}100 \% \\
100 \%\end{array}$ \\
\hline \multirow[t]{5}{*}{ 5.2.2.1.3 } & $\begin{array}{l}\text { System Integration and Cross- } \\
\text { cutting Functions } \\
\text { AlDiSabatino }\end{array}$ & Oct 00 & Nov 00 & Dec 00 & Jan 01 & Feb 01 & Mar 01 & Apr 01 & May 01 & Jun 01 & Jul 01 & Aug 01 & Sep 01 & Totals & $\begin{array}{l}\text { Cum. } \\
\text { var. }\end{array}$ \\
\hline & \begin{tabular}{|l|} 
Manpower Projection \\
Major Procurement Projection \\
FFO0 Liens
\end{tabular} & $\begin{array}{r}31,891 \\
2,861\end{array}$ & 36,609 & 35,500 & $\begin{array}{r}35,500 \\
100,000\end{array}$ & 35,500 & 35,000 & 35,000 & 35,000 & 35,000 & 35,000 & 25,000 & 25,000 & $\begin{array}{l}400,000 \\
100,000 \\
2,861\end{array}$ & \\
\hline & Total Monthly Projection & 34,752 & 36,609 & 35,500 & 135,500 & 35,500 & 35,000 & 35,000 & 35,000 & 35,000 & 35,000 & 25,000 & 25,000 & $\begin{array}{l}502,861 \\
\end{array}$ & \\
\hline & $\begin{array}{l}\text { Cumulative Monthly Projection } \\
\text { Cumulative Costs }\end{array}$ & $\begin{array}{l}34,752 \\
31,891\end{array}$ & $\begin{array}{l}71,361 \\
49,286\end{array}$ & $\begin{array}{r}106,861 \\
69,730\end{array}$ & 242,361 & 277,861 & 312,861 & 347,861 & 382,861 & 417,861 & 452,861 & 477,861 & 502,861 & & $35 \%$ \\
\hline & Cumulative Costs + Liens & 34,752 & 52,147 & 73,411 & & & & & & & & & & & $31 \%$ \\
\hline \multirow[t]{4}{*}{ 5.2.2.2.1.4 } & $\begin{array}{l}\text { Material Transport } \\
\text { Al DiSabatino }\end{array}$ & Oct 00 & Nov 00 & Dec 00 & Jan 01 & Feb 01 & Mar 01 & Apr 01 & May 01 & Jun 01 & Jul 01 & Aug 01 & Sep 01 & Totals & $\begin{array}{l}\text { Cum. } \\
\text { Var. }\end{array}$ \\
\hline & \begin{tabular}{|l|} 
Manpower Projection \\
Major Procurement Projection \\
FYoo Liens \\
Total Monthly Projection
\end{tabular} & 0 & 0 & 0 & 0 & 0 & $\overline{0}$ & 0 & 0 & 0 & 0 & 0 & & $\begin{array}{l}0 \\
0 \\
0\end{array}$ & \\
\hline & Cumulative Monthly Projection & 0 & 0 & 0 & 0 & 0 & 0 & 0 & 0 & 0 & 0 & 0 & & & \\
\hline & $\begin{array}{l}\text { Cumulative Costs } \\
\text { Cumulative Costs + Liens }\end{array}$ & $\begin{array}{l}0 \\
0 \\
\end{array}$ & $\begin{array}{l}0 \\
0 \\
0\end{array}$ & $\begin{array}{l}0 \\
0 \\
\end{array}$ & & & & & & & & & & & \#DIV/0! \\
\hline \multirow[t]{6}{*}{ 5.2.2.2. } & $\begin{array}{l}\text { Technical Support \& Integration } \\
\text { Total } \\
\text { Lead - Al DiSabatino }\end{array}$ & Oct 00 & Nov 00 & Dec 00 & Jan 01 & Feb 01 & Mar 01 & Apr 01 & May 01 & Jun 01 & Jul 01 & Aug 01 & Sep 01 & Totals & $\begin{array}{l}\text { Cum. } \\
\text { Var. }\end{array}$ \\
\hline & Manpower Projection & 63,011 & 58,609 & 67,380 & 55,500 & 45,500 & 45,000 & 40,000 & 40,000 & 40,000 & 40,000 & 30,000 & 30,000 & 555,000 & \\
\hline & Major Procurement Projection & & & & 220,000 & 0 & & 0 & & 0 & & 0 & 0 & 220,000 & \\
\hline & $\begin{array}{l}\text { FYo0 Liens } \\
\text { Total Monthly Proiection }\end{array}$ & $\begin{array}{r}3,996 \\
66917\end{array}$ & $\begin{array}{r}0 \\
58,609\end{array}$ & $\begin{array}{r}0 \\
67380\end{array}$ & $\begin{array}{r}0 \\
275,500\end{array}$ & $\begin{array}{r}0 \\
45,500\end{array}$ & $\begin{array}{r}0 \\
45,000\end{array}$ & $\begin{array}{r}0 \\
40,000\end{array}$ & $\begin{array}{r}0 \\
40,000\end{array}$ & $\begin{array}{r}0 \\
40,000\end{array}$ & $\begin{array}{r}0 \\
40,000\end{array}$ & $\begin{array}{r}0 \\
30,000\end{array}$ & $\begin{array}{r}0 \\
30,000\end{array}$ & $\begin{array}{r}3,996 \\
778,966\end{array}$ & \\
\hline & $\begin{array}{l}\text { Cumulative Monthly Projection } \\
\text { Cumulative Costs }\end{array}$ & $\begin{array}{l}66,917 \\
63011\end{array}$ & $\begin{array}{l}125,526 \\
118,832\end{array}$ & $\begin{array}{l}192,906 \\
144,506\end{array}$ & 468,406 & 513,906 & 558,906 & 598,906 & 638,906 & 678,906 & 718,906 & 748,906 & 778,906 & & $25 \%$ \\
\hline & \begin{tabular}{|l} 
Cumulative Costs \\
Cumulative Costs + Liens
\end{tabular} & 66,917 & $\begin{array}{l}118,832 \\
122,738\end{array}$ & $\begin{array}{l}144,506 \\
149,231\end{array}$ & & & & & & & & & & & $23 \%$ \\
\hline
\end{tabular}

Cumulative Monthly Project

umulative Costs + Lien

\section{0,000 New FY01 Funds 2,861 Comm. C C 502,861 Total FY01 Funding}

0 New FY01 Funds 0 Comm. C/O
Uncommitted C/O
0 Total FY01 Funding

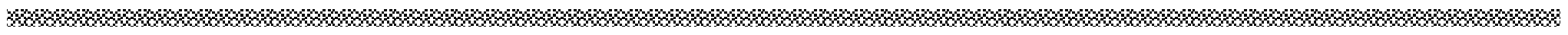

\begin{tabular}{|c|c|c|c|c|c|c|c|c|c|c|c|c|c|c|c|}
\hline 5.2.2.2.2.3 & $\begin{array}{l}\text { Processt Control Model } \\
\text { Development } \\
\text { Bart Ebbinghaus }\end{array}$ & Oct 00 & Nov 00 & Dec 00 & Jan 01 & Feb 01 & Mar 01 & Apr 01 & May 01 & Jun 01 & Jul 01 & Aug 01 & Sep 01 & Totals & $\begin{array}{l}\text { Cum. } \\
\text { Var. }\end{array}$ \\
\hline & $\begin{array}{l}\text { Manpower Projection } \\
\text { Major Procurement Projection } \\
\text { FY0o Liens } \\
\text { Total }\end{array}$ & $\begin{array}{r}79,000 \\
89,708 \\
168708\end{array}$ & 48,000 & 36,000 & 34,000 & 28,000 & 17,000 & & & & & & & $\begin{array}{r}242,000 \\
0 \\
89,708 \\
331708\end{array}$ & \\
\hline & Total Monthly Projection & 168,708 & 48,000 & 36,000 & 34,000 & 28,000 & 17,000 & 0 & 0 & 0 & 0 & 0 & 0 & 331,708 & \\
\hline & \begin{tabular}{l|} 
Cumulative Monthly Projection \\
Cumulative Costs
\end{tabular} & $\begin{array}{r}168,708 \\
78,539\end{array}$ & $\begin{array}{l}216,708 \\
130,174\end{array}$ & $\begin{array}{l}252,708 \\
221,062\end{array}$ & 286,708 & 314,708 & 331,708 & 331,708 & 331,708 & 331,708 & 331,708 & 331,708 & 331,708 & & $13 \%$ \\
\hline & Cumulative Costs + Liens & 168,246 & 219,881 & 270,770 & & & & & & & & & & & \\
\hline
\end{tabular}




\section{LLNL FY01 Spend Plan}

5.2.2.2 Immobilized Form Development

\begin{tabular}{|c|c|c|c|c|c|c|c|c|c|c|c|c|c|c|}
\hline $\begin{array}{l}\text { Total } \\
\text { Lead -Guy Armantrout }\end{array}$ & Oct 00 & Nov 00 & Dec 00 & Jan 01 & Feb 01 & Mar 01 & Apr 01 & May 01 & Jun 01 & Jul 01 & Aug 01 & Sep 01 & Totals & $\begin{array}{l}\text { Cum. } \\
\text { Var. }\end{array}$ \\
\hline Manpower Projection & 79,000 & 48,000 & 36,000 & 34,000 & 28,000 & 17,000 & 0 & 0 & 0 & 0 & 0 & 0 & 242,000 & \\
\hline Major Procurement Projection & 0 & & & & & 0 & 0 & 0 & 0 & 0 & 0 & 0 & & \\
\hline FYoo Liens & & & & & & & 0 & 0 & 0 & 0 & 0 & 0 & $\begin{array}{r}89,708 \\
\end{array}$ & \\
\hline Total Monthly Projection & 168,708 & 48,000 & 36,000 & 34,000 & 28,000 & 17,000 & 0 & 0 & 0 & 0 & 0 & 0 & 331,708 & \\
\hline Cumulative Monthly Projection & 168,708 & 216,708 & 252,708 & 286,708 & 314,708 & 331,708 & 331,708 & \begin{tabular}{ll|l}
331,708 \\
\end{tabular} & 331,708 & 331,708 & 331,708 & 331,708 & & \\
\hline Cumulative Costs & $\begin{array}{r}78,539 \\
16846\end{array}$ & 130,174 & 221,062 & & & & & & & & & & & $13 \%$ \\
\hline
\end{tabular}

\$

\begin{tabular}{|c|c|c|c|c|c|c|c|c|c|c|c|c|c|c|c|}
\hline 5.2.2.3.3 & $\begin{array}{l}\text { Material Size Reduction } \\
\text { Mark Bronson }\end{array}$ & Oct 00 & Nov 00 & Dec 00 & Jan 01 & Feb 01 & Mar 01 & Apr 01 & May 01 & Jun 01 & Jul 01 & Aug 01 & Sep 01 & Totals & $\begin{array}{l}\text { Cum. } \\
\text { Var. }\end{array}$ \\
\hline & \begin{tabular}{|l} 
Manpower Projection \\
Major Procurement Projection \\
FYoo Liens \\
Total Monthly Projection
\end{tabular} & $\begin{array}{l}0 \\
0 \\
0 \\
0\end{array}$ & 0 & 0 & 0 & 0 & 0 & 0 & 0 & 0 & 0 & 0 & & \begin{tabular}{l|l} 
\\
0 \\
0 \\
0
\end{tabular} & \\
\hline & $\begin{array}{l}\text { Cumulative Monthly Projection } \\
\text { Cumulative Costs }\end{array}$ & $\begin{array}{r}0 \\
0 \\
-2,270 \\
-270\end{array}$ & $\begin{array}{r}0 \\
-2,270 \\
-2,270\end{array}$ & $\begin{array}{r}0 \\
-2,270 \\
-2,270\end{array}$ & 0 & 0 & 0 & $\frac{0}{0}$ & $0^{0}$ & 0 & 0 & 0 & & & $\begin{array}{l}\# \text { DIV } / 0 ! \\
\text { \#DIV } 00 !\end{array}$ \\
\hline 5.2.2.3.4. & $\begin{array}{l}\text { Material Unpacking and Sorting } \\
\text { Mark Bronson }\end{array}$ & Oct 00 & Nov 00 & Dec 00 & Jan 01 & Feb 01 & Mar 01 & Apr 01 & May 01 & Jun 01 & Jul 01 & Aug 01 & Sep 01 & Totals & $\begin{array}{l}\text { Cum. } \\
\text { Var. }\end{array}$ \\
\hline & \begin{tabular}{|l|} 
Manpower Projection \\
Major Procurement Projection \\
FYoo Liens \\
Total Monthly Projection \\
\end{tabular} & 0 & 0 & 0 & 0 & 0 & 0 & 0 & 0 & 0 & 0 & 0 & 0 & $\begin{array}{l}0 \\
0\end{array}$ & \\
\hline & Cumulative Monthly Projection & 0 & 0 & 0 & 0 & 0 & 0 & 0 & 0 & 0 & 0 & 0 & & & \\
\hline & $\begin{array}{l}\text { lumulative Costs } \\
\text { Cumulative Costs + Liens } \\
\end{array}$ & $\begin{array}{l}243 \\
243 \\
\end{array}$ & $\begin{array}{l}243 \\
243 \\
\end{array}$ & $\begin{array}{r}243 \\
243 \\
\end{array}$ & & & & & & & & & & & | \\
\hline 5.2.2.3.6 & $\begin{array}{l}\text { Metal Conversion } \\
\text { Mark Bronson }\end{array}$ & Oct 00 & Nov 00 & Dec 00 & Jan 01 & Feb 01 & Mar 01 & Apr 01 & May 01 & Jun 01 & Jul 01 & Aug 01 & Sep 01 & Totals & $\begin{array}{l}\text { Cum. } \\
\text { Var. }\end{array}$ \\
\hline & \begin{tabular}{|l|} 
Manpower Projection \\
Major Procurement Projection \\
FYoo Liens \\
Total Monthly Projection \\
\end{tabular} & $\begin{array}{r}160,000 \\
18,204 \\
178,204 \\
\end{array}$ & 230,000 & 150,000 & 450,000 & 220,000 & 210,000 & 151,000 & 0 & 0 & 0 & 0 & & \begin{tabular}{r|}
$1,571,000$ \\
0 \\
18,204 \\
$1,589,204$ \\
\end{tabular} & \\
\hline & Cumulative Monthly Projection & 178,204 & 408,204 & 558,204 & $1,008,204$ & $1,228,204$ & $1,438,204$ & $1,589,204$ & $1,589,204$ & $1,589,204$ & $1,589,204$ & $1,589,204$ & $1,589,204$ & & \\
\hline & $\begin{array}{l}\text { Cumulative Costs } \\
\text { Cumulative Costs + Liens }\end{array}$ & $\begin{array}{l}137,1,87 \\
168,972 \\
\end{array}$ & $\begin{array}{l}461,164 \\
491,739 \\
\end{array}$ & $\begin{array}{r}800,732 \\
1,109,298 \\
\end{array}$ & & & & & & & & & & & $\begin{array}{r}-43 \% \\
-99 \% \\
\end{array}$ \\
\hline 5.2.2.3.7. & $\begin{array}{l}\text { Impure Oxide Feed Preparation } \\
\text { Mark Bronson }\end{array}$ & Oct 00 & Nov 00 & Dec 00 & Jan 01 & Feb 01 & Mar 01 & Apr 01 & May 01 & Jun 01 & Jul 01 & Aug 01 & Sep 01 & Totals & $\begin{array}{l}\text { Cum. } \\
\text { var. }\end{array}$ \\
\hline & \begin{tabular}{|l} 
Manpower Projection \\
Major Procurement Projection \\
FYo0 Liens \\
Total Monthly Projection
\end{tabular} & 25,000 & 35,000 & 35,000 & 85,000 & 35,000 & 50,000 & 20,000 & 30,000 & 30,000 & 20,000 & 20,000 & 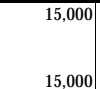 & $\begin{array}{r}400,000 \\
0 \\
0 \\
400,000\end{array}$ & \\
\hline & Cumulative Monthly Projection & 25,000 & 60,000 & 95,000 & 180,000 & 215,000 & 265,000 & 285,000 & 315,000 & 345,000 & 365,000 & 385,000 & 400,000 & & \\
\hline & $\begin{array}{l}\text { Cumulative Costs } \\
\text { Cumulative Costs + Liens }\end{array}$ & $\begin{array}{r}24,078 \\
24,078 \\
\end{array}$ & $\begin{array}{l}49,606 \\
49,606\end{array}$ & $\begin{array}{l}100,545 \\
100,545\end{array}$ & & & & & & & & & & & -6\% $-6 \%$ \\
\hline 5.2.2.3.8 & $\begin{array}{l}\text { Materials Characterization } \\
\text { Mark Bronson }\end{array}$ & Oct 00 & Nov 00 & Dec 00 & $\operatorname{Jan} 01$ & Feb 01 & Mar 01 & Apr 01 & May 01 & Jun 01 & Jul 01 & Aug 01 & Sep 01 & Totals & $\begin{array}{l}\text { Cum. } \\
\text { var. }\end{array}$ \\
\hline & \begin{tabular}{|l|} 
Manpower Projection \\
Major Procurement Projection \\
FYoo Liens \\
\end{tabular} & $\begin{array}{l}37,000 \\
20,905 \\
57005\end{array}$ & 50,000 & 50,000 & 50,000 & 38,000 & 25,000 & 25,000 & 25,000 & 25,000 & 25,000 & 25,000 & 25,000 & $\begin{aligned} 400,000 \\
0 \\
20,905 \\
42095\end{aligned}$ & \\
\hline & 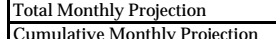 & $\frac{57,905}{55905}$ & 50,000 & $\begin{array}{r}50,000 \\
157905\end{array}$ & $\begin{array}{r}50,000 \\
207905\end{array}$ & $\frac{38,000}{24505}$ & 25,0000 & 25,000 & $\begin{array}{r}25,000 \\
32005\end{array}$ & $\begin{array}{r}25,000 \\
345,905\end{array}$ & $\begin{array}{r}25,000 \\
370905\end{array}$ & 25,000 & $\frac{25,000 \mid}{42095 \mid}$ & $420,905 \mid$ & \\
\hline & $\begin{array}{l}\text { Umulative Monthy Projection } \\
\text { Cumulative Costs } \\
\text { Cumulative Costs } 5 \text { Liens }\end{array}$ & $\begin{array}{l}37,7,230 \\
58,735\end{array}$ & $\begin{array}{l}102,852 \\
123,757\end{array}$ & $\begin{array}{l}184,156 \\
184,890\end{array}$ & & & & & & & & & & & $\begin{array}{l}-17 \% \\
-17 \%\end{array}$ \\
\hline
\end{tabular}

0 New FY01 Funds Uncommitted C/O
0 Total FY01 Funding 0 Total FYol Funding

0 New FY01 Fund Uncommitted C/O
0 Total FY01 Funding

1,571,000 New FY01 Funds 18,204 Comm. C/O Uncommitted C/O
1,589,204 Total FY01 Funding 0 Comm. C/O Uncommitted C/O
400,000 Total FY01 Funding

400,000 New FY01 Fund Uncommitted C/O
420,905 Total FY01 Funding 
LLNL FY01 Spend Plan

5.2.2.3 Plutonium Conversion Process/

\begin{tabular}{|c|c|c|c|c|c|c|c|c|c|c|c|c|c|c|}
\hline $\begin{array}{l}\text { Equipment Development Total } \\
\text { Lead - Mark Bronson }\end{array}$ & Oct 00 & Nov 00 & Dec 00 & Jan 01 & Feb 01 & Mar 01 & Apr 01 & May 01 & Jun 01 & Jul 01 & Aug 01 & Sep 01 & Totals & $\begin{array}{l}\text { Cum. } \\
\text { Var. }\end{array}$ \\
\hline Manpower Projection & 222,000 & 315,000 & 235,000 & 585,000 & 293,000 & 285,000 & 196,000 & 55,000 & 55,000 & 45,000 & 45,000 & 40,000 & $2,371,000$ & \\
\hline $\begin{array}{l}\text { Major Procurement Projection } \\
\text { FY00 Liens }\end{array}$ & $\begin{array}{r}0 \\
39109\end{array}$ & & & & & & & & 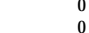 & $\begin{array}{l}0 \\
0\end{array}$ & 0 & $\begin{array}{l}0 \\
0\end{array}$ & $\begin{array}{r}0 \\
39,109\end{array}$ & \\
\hline 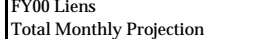 & 261,109 & 315,000 & 235,000 & 585,000 & 293,000 & 285,000 & 196,000 & 55,000 & 55,000 & 45,000 & 45,000 & 40,000 & $\begin{array}{r}3,410,109 \\
2,109\end{array}$ & \\
\hline Cumulative Monthly Projection & 261,109 & 576,109 & 811,109 & $1,396,109$ & $1,689,109$ & 1,974,109 & $2,170,109$ & $2,225,109$ & $2,280,109$ & $2,325,109$ & $2,370,109$ & $2,410,109$ & & \\
\hline $\begin{array}{l}\text { Cumulative Costs } \\
\text { Cumulative Costaten }\end{array}$ & $\begin{array}{l}196,469 \\
25975\end{array}$ & $\begin{array}{l}611,595 \\
66307\end{array}$ & $\begin{array}{l}1,083,406 \\
139207\end{array}$ & & & & & & & & & & & . \\
\hline & 249,758 & 663,075 & $1,392,707$ & & & & & & & & & & & $-72 \%$ \\
\hline
\end{tabular}

Cumulative Costs + Liens

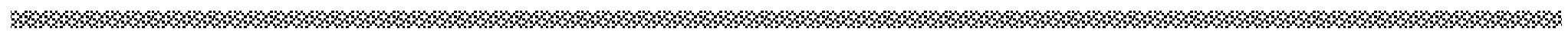

\begin{tabular}{|c|c|c|c|c|c|c|c|c|c|c|c|c|c|c|c|}
\hline 5.2.2.4.2.1 & $\begin{array}{l}\text { Ceramification Process } \\
\text { Development } \\
\text { Guy Armantrout }\end{array}$ & Oct 00 & Nov 00 & Dec 00 & Jan 01 & Feb 01 & Mar 01 & Apr 01 & May 01 & Jun 01 & Jul 01 & Aug 01 & Sep 01 & Totals & $\begin{array}{l}\text { Cum. } \\
\text { Var. }\end{array}$ \\
\hline & \begin{tabular}{|l|} 
Manpower Projection \\
Major Procurement Projection \\
FY00 Liens \\
Total Monthly Projection
\end{tabular} & $\begin{array}{r}3,500 \\
60,073 \\
63,573 \\
\end{array}$ & $\begin{array}{l}3,500 \\
3,500\end{array}$ & $\begin{array}{l}3,500 \\
3,500\end{array}$ & $\begin{array}{l}3,500 \\
3,500\end{array}$ & $\begin{array}{r}25,000 \\
5,000 \\
30,000\end{array}$ & $\begin{array}{r}30,000 \\
5,000 \\
35,000\end{array}$ & $\begin{array}{r}53,000 \\
5,000 \\
58,000\end{array}$ & $\begin{array}{r}55,000 \\
4,000 \\
59,000\end{array}$ & $\begin{array}{r}55,000 \\
4,000 \\
59,000\end{array}$ & $\begin{array}{r}60,000 \\
4,000 \\
64,000\end{array}$ & $\begin{array}{r}55,000 \\
4,000 \\
59,000\end{array}$ & $\begin{array}{r}55,000 \\
4,000 \\
59,000\end{array}$ & $\begin{array}{r}402,000 \\
35,000 \\
60,073 \\
497,073\end{array}$ & \\
\hline & Cumulative Monthly Projection & 63,573 & 67,073 & 70,573 & 74,073 & 104,073 & 139,073 & 197,073 & 256,073 & 315,073 & 379,073 & 438,073 & 497,073 & & \\
\hline & $\begin{array}{l}\text { Cumulative Costs } \\
\text { Cumulative Costs + Liens }\end{array}$ & $\begin{array}{r}3,418 \\
63,492 \\
\end{array}$ & $\begin{array}{l}12,292 \\
72,365 \\
\end{array}$ & $\begin{array}{l}106,838 \\
106,911 \\
\end{array}$ & & & & & & & & & & & $\begin{array}{l}-51 \% \\
-51 \% \\
\end{array}$ \\
\hline \multirow[t]{5}{*}{ 5.2.2.4.2.2. } & $\begin{array}{l}\text { Plutonium Ceramic Test Facility } \\
\text { (PuCTF) } \\
\text { Guy Armantrout }\end{array}$ & Oct 00 & Nov 00 & Dec 00 & Jan 01 & Feb 01 & Mar 01 & Apr 01 & May 01 & Jun 01 & Jul 01 & Aug 01 & Sep 01 & Totals & $\begin{array}{l}\text { Cum. } \\
\text { Var. }\end{array}$ \\
\hline & \begin{tabular}{|l|} 
Manpower Projection \\
Major Procurement Projection \\
FY00 Liens
\end{tabular} & $\begin{array}{r}580,000 \\
30,000 \\
140,678\end{array}$ & $\begin{array}{r}600,000 \\
30,000\end{array}$ & $\begin{array}{r}550,000 \\
30,000\end{array}$ & $\begin{array}{r}600,000 \\
20,000\end{array}$ & $\begin{array}{r}500,000 \\
0\end{array}$ & $\begin{array}{r}400,000 \\
0\end{array}$ & $\begin{array}{r}90,000 \\
0\end{array}$ & $\begin{array}{r}5,000 \\
0\end{array}$ & 5,000 & 5,000 & 5,000 & \begin{tabular}{l|l|l}
5,000 \\
\end{tabular} & $\begin{array}{r}3,345,000 \\
110,000 \\
140,678\end{array}$ & \\
\hline & Total Monthly Projection & 750,678 & 630,000 & 580,000 & 620,000 & 500,000 & 400,000 & 90,000 & 5,000 & 5,000 & 5,000 & 5,000 & 5,000 & $3,595,678$ & \\
\hline & Cumulative Monthly Projection & 750,678 & $1,380,678$ & $1,960,678$ & $2,580,678$ & $3,080,678$ & $3,480,678$ & $3,570,678$ & $3,575,678$ & $3,580,678$ & $3,585,678$ & $3,590,678$ & $|3,595,678|$ & & \\
\hline & $\begin{array}{l}\text { Cumulative Costs } \\
\text { Cumulative Costs + Liens }\end{array}$ & $\begin{array}{l}580,540 \\
751,477\end{array}$ & $\begin{array}{l}1,125,428 \\
1,335,075 \\
\end{array}$ & $\begin{array}{l}1,757,302 \\
1,849,775 \\
\end{array}$ & & & & & & & & & & & $\begin{array}{l}10 \% \\
6 \% \\
6\end{array}$ \\
\hline \multirow[t]{4}{*}{ 5.2.2.4.3 } & $\begin{array}{l}\text { Puck NDE/MC\&A for Process } \\
\text { Control and SNM Accountability } \\
\text { Guy Armantrout }\end{array}$ & Oct 00 & Nov 00 & Dec 00 & Jan 01 & Feb 01 & Mar 01 & Apr 01 & May 01 & Jun 01 & Jul 01 & Aug 01 & Sep 01 & Totals & $\begin{array}{l}\text { Cum. } \\
\text { Var. }\end{array}$ \\
\hline & \begin{tabular}{|l} 
Manpower Projection \\
Major Procurement Projection \\
FY00 Liens \\
Total Monthly Projection
\end{tabular} & 0 & 0 & 0 & 0 & 0 & 30,000 & $\begin{array}{r}100,000 \\
10,000 \\
110,000\end{array}$ & $\begin{array}{l}80,000 \\
10,000 \\
90,000\end{array}$ & $\begin{array}{r}80,000 \\
6,000 \\
86,000\end{array}$ & $\begin{array}{l}60,000 \\
60,000\end{array}$ & 20,000 & 20,000 & $\begin{array}{r}390,000 \\
26,000 \\
0 \\
416,000\end{array}$ & \\
\hline & Cumulative Monthly Projection & 0 & 0 & 0 & 0 & 0 & 30,000 & 140,000 & 230,000 & 316,000 & 376,000 & 396,000 & 416,000 & & \\
\hline & $\begin{array}{l}\text { Cumulative Costs } \\
\text { Cumulative Costs }+ \text { Liens }\end{array}$ & $\begin{array}{l}-13 \\
-13\end{array}$ & $\begin{array}{l}2,355 \\
2,355\end{array}$ & $\begin{array}{l}3,520 \\
3,520\end{array}$ & & & & & & & & & & & $\begin{array}{l}\text { \#DIV/0! } \\
\text { \#DIV } / 0 !\end{array}$ \\
\hline \multirow[t]{4}{*}{ 5.2.2.4.4 } & $\begin{array}{l}\text { Recycle of Unacceptable Materials } \\
\text { Guy Armantrout }\end{array}$ & Oct 00 & Nov 00 & Dec 00 & Jan 01 & Feb 01 & Mar 01 & Apr 01 & May 01 & Jun 01 & Jul 01 & Aug 01 & Sep 01 & Totals & $\begin{array}{l}\text { Cum. } \\
\text { Var. }\end{array}$ \\
\hline & \begin{tabular}{|l} 
Manpower Projection \\
Major Procurement Projection \\
FYYo Liens \\
Total Monthly Projection \\
\end{tabular} & 0 & 0 & 0 & 0 & 0 & 5,000 & 10,000 & 12,000 & 0 & 0 & 0 & 足 & $\begin{array}{r}27,000 \\
0 \\
0 \\
27,000 \\
\end{array}$ & \\
\hline & Monthly Projection & 0 & 0 & 0 & 0 & 0 & 5,000 & 15,000 & 27,000 & 27,000 & 27,000 & 27,000 & 27,000 & & \\
\hline & \begin{tabular}{|l} 
Cumulative Costs \\
Cumulative Costs + Liens
\end{tabular} & $\begin{array}{l}32 \\
32\end{array}$ & $\begin{array}{l}65 \\
65\end{array}$ & $\begin{array}{l}65 \\
65\end{array}$ & & & & & & & & & & & | \\
\hline \multirow[t]{7}{*}{5.2 .2 .4} & $\begin{array}{l}\text { First Stage Immobilization } \\
\text { Process/Equip Development Total } \\
\text { Lead - Guy Armantrout }\end{array}$ & Oct 00 & Nov 00 & Dec 00 & Jan 01 & Feb 01 & Mar 01 & Apr 01 & May 01 & Jun 01 & Jul 01 & Aug 01 & Sep 01 & Totals & $\begin{array}{l}\text { Cum. } \\
\text { Var. }\end{array}$ \\
\hline & Manpo & 583,500 & 603,500 & 553,500 & 603,500 & 525,000 & 465,000 & 253,000 & $\overline{152,000}$ & 140,000 & 125,000 & 80,000 & \begin{tabular}{|l|l|}
80,000 \\
\end{tabular} & $|4,164,000|$ & \\
\hline & rement Pro & & 30,000 & 30,000 & 20,000 & 5,000 & 5,000 & 15,000 & 14,000 & 10,000 & 4,000 & 4,000 & 4,000 & & \\
\hline & FY00 Lie & 200 & & & & & & & & & & 0 & & & \\
\hline & Total Monthly Projection & 814,251 & 633,500 & 583,500 & 623,500 & 530,000 & 470,000 & 268,000 & 166,000 & 150,000 & 129,000 & 84,000 & 84,000 & $4,535,751$ & \\
\hline & \begin{tabular}{|l|} 
Cumulative Monthly Projection \\
Cumulative Costs
\end{tabular} & $\begin{array}{l}814,251 \\
583,977\end{array}$ & $\begin{array}{l}1,447,751 \\
1,140,140\end{array}$ & $\begin{array}{l}2,031,251 \\
1,867,724\end{array}$ & $2,654,751$ & $\begin{array}{ll}3,184,751 \\
\end{array}$ & $3,654,751$ & $3,922,751$ & $4,088,751$ & $4,238,751$ & $4,367,751$ & $4,451,751$ & $4,535,751$ & & $8 \%$ [ \\
\hline & Cumulative Costs + Liens & 814,988 & $1,409,860$ & $1,960,271$ & & & & & & & & & & & $\%$ \\
\hline
\end{tabular}

437,000 New FY01 Funds

60,073 Comm. C/O
Uncommitted C/O

2,371,000 New FY01 Funds

0 Uncommitted C/O
410,109 Total FY01 Funding

2,410,109 Total FY01 Funding

497,073 Total FY01 Funding

3,455,000 New FY01 Fund
140,677 Comm. C/O

Uncommitted C/O
3,595,677 Total FY01 Funding

416,000 New FY01 Funds

Comm. C/O
Uncommitted C/O

416,000 Total FY01 Funding

27,000 New FY01 Funds

Uncommitted C/O
27,000 Total FY01 Funding

ঋ 
LLNL FY01 Spend Plan

\begin{tabular}{|c|c|c|c|c|c|c|c|c|c|c|c|c|c|c|c|}
\hline 5.2.2.2.5.1.2 & $\begin{array}{l}\text { Canister Pour Analysis and Testing } \\
\text { Tehmau Kan }\end{array}$ & Oct 00 & Nov 00 & Dec 00 & Jan 01 & Feb 01 & Mar 01 & Apr 01 & May 01 & Jun 01 & Jul 01 & Aug 01 & Sep 01 & Totals & $\begin{array}{l}\text { Cum. } \\
\text { Var. }\end{array}$ \\
\hline & $\begin{array}{l}\text { Manpower Projection } \\
\text { Major Procurement Projection } \\
\text { FYoo Liens }\end{array}$ & $\begin{array}{r}3,800 \\
779 \\
4,579\end{array}$ & 3,800 & 11,400 & 9,900 & 7,400 & 7,400 & 4,000 & 2,300 & 0 & 0 & 0 & $\overline{0}$ & $\begin{array}{r}50,000 \\
0 \\
779 \\
50,779\end{array}$ & \\
\hline & $\mid$\begin{tabular}{|l} 
Total Monthly Projection \\
Cumulative Monthly Projection
\end{tabular} & 4,579 & $\frac{3,300}{8,379}$ & $\frac{11,400}{19,779}$ & $\begin{array}{r}9,900 \\
29,679\end{array}$ & $\begin{array}{r}7,400 \\
37,079\end{array}$ & $\frac{1,4400}{44,479}$ & $\begin{array}{r}4,000 \\
48,479\end{array}$ & $\frac{\frac{2,300}{50,779}}{5}$ & $\frac{0}{50,779}$ & $\frac{0}{50,779}$ & 50,779 & $\frac{0}{50,779}$ & 50,779 - & \\
\hline & $\begin{array}{l}\text { Cumulative Costs } \\
\text { Cumulative Costs + Liens }\end{array}$ & $\begin{array}{l}3,833 \\
4,611 \\
\end{array}$ & $\begin{array}{r}3,839 \\
4,618 \\
\end{array}$ & $\begin{array}{r}2,668 \\
4,344 \\
\end{array}$ & & & & & & & & & & & $\begin{array}{l}87 \% \\
78 \% \\
\end{array}$ \\
\hline 5.2.2.5 & $\begin{array}{l}\text { Second Stage Immobilization } \\
\text { Process/Equip Development Total } \\
\text { Lead - Tehmau Kan }\end{array}$ & Oct 00 & Nov 00 & Dec 00 & Jan 01 & Feb 01 & Mar 01 & Apr 01 & May 01 & Jun 01 & Jul 01 & Aug 01 & Sep 01 & Totals & $\begin{array}{l}\text { Cum. } \\
\text { var. }\end{array}$ \\
\hline & \begin{tabular}{|l} 
Manpower Projection \\
Major Procurement Proiection
\end{tabular} & $\begin{array}{l}3,800 \\
0\end{array}$ & $\begin{array}{l}3,800 \\
0\end{array}$ & $\begin{aligned} 11,400 \\
0\end{aligned}$ & $\begin{aligned} 9,900 \\
0\end{aligned}$ & $\begin{array}{l}7,400 \\
0\end{array}$ & 7,400 & $\begin{array}{l}4,000 \\
0\end{array}$ & $\begin{array}{r}2,300 \\
0\end{array}$ & $\begin{array}{l}0 \\
0\end{array}$ & $\begin{array}{l}0 \\
0\end{array}$ & $\begin{array}{l}0 \\
0\end{array}$ & $\begin{array}{c}0 \\
0 \\
0\end{array}$ & 50,000 & \\
\hline & 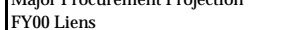 & 779 & 0 & 0 & 0 & 0 & 0 & 0 & o & 0 & o & 0 & . & 779 & \\
\hline & Total Monthly Projection & 4,579 & 3,800 & 11,400 & 9,900 & 7,400 & 7,400 & 4,000 & 2,300 & 0 & 0 & 0 & 0 & 50,779 & \\
\hline & Cumulative Monthly Projection & 4,579 & 8,379 & 19,779 & 29,679 & 37,079 & 44,479 & 48,479 & 50,779 & 50,779 & 50,779 & 50,779 & 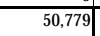 & & \\
\hline & $\begin{array}{l}\text { Cumulative Costs } \\
\text { Cumulative Costs + Liens }\end{array}$ & $\begin{array}{l}3,833 \\
4,611\end{array}$ & $\begin{array}{l}3,839 \\
4,618\end{array}$ & $\begin{array}{l}2,668 \\
4,344\end{array}$ & & & & & & & & & & & $\begin{array}{l}87 \% \\
78 \%\end{array}$ \\
\hline
\end{tabular}

ঋ\%

\begin{tabular}{|c|c|c|c|c|c|c|c|c|c|c|c|c|c|c|c|}
\hline 5.2.3.1.5 & $\begin{array}{l}\text { Single-Pass Flow-Through Tests } \\
\text { Henry Shaw }\end{array}$ & Oct 00 & Nov 00 & Dec 00 & Jan 01 & Feb 01 & Mar 01 & Apr 01 & May 01 & Jun 01 & Jul 01 & Aug 01 & Sep 01 & Totals & $\begin{array}{l}\text { Cum. } \\
\text { Var. }\end{array}$ \\
\hline & \begin{tabular}{|l|} 
Manpower Projection \\
Major Procurement Projection \\
FYoo Liens \\
Total Monthly Projection
\end{tabular} & 21,538 & 21,538 & 21,538 & 26,923 & 21,538 & 26,923 & 21,538 & 21,538 & 26,923 & 21,538 & 21,538 & 26,923 & $\begin{array}{r}280,000 \\
0 \\
0 \\
280,000\end{array}$ & \\
\hline & Cumulative Monthly Projection & 21,538 & $\begin{array}{ll}21,300 \\
43,077\end{array}$ & $\frac{21,530}{64,615}$ & $\begin{array}{ll}\frac{20,953}{91,538} \\
\end{array}$ & $\begin{array}{r}2,13,00 \\
11,077\end{array}$ & $\frac{20,953}{140,000}$ & $\frac{21,538}{161,538}$ & $\frac{11,300}{183,077}$ & $\frac{26,933}{210000}$ & $\begin{array}{r}2,1,538 \\
231,538\end{array}$ & $\frac{21,138}{253,077}$ & $\frac{26,933 \mid}{280,000 \mid}$ & $280,000 \mid$ & \\
\hline & Cumulativ & & & & & & & & & & & & & & \\
\hline & Cumulative Costs + Liens & 21,341 & 46,931 & 71,81 & & & & & & & & & & & \\
\hline \multirow[t]{5}{*}{ 5.2.3.1.6 } & $\begin{array}{l}\text { Dissolution Model Development } \\
\text { Henry Sharw }\end{array}$ & Oct 00 & Nov 00 & Dec 00 & Jan 01 & Feb 01 & Mar 01 & Apr 01 & May 01 & Jun 01 & Jul 01 & Aug 01 & Sep 01 & Totals & $\begin{array}{l}\text { Cum. } \\
\text { Var. }\end{array}$ \\
\hline & $\begin{array}{l}\text { Manpower Projection } \\
\text { Major Procurement Projection } \\
\text { FYO0 Liens }\end{array}$ & 9,231 & 9,231 & 9,231 & 11,538 & 9,231 & 11,538 & 9,231 & 9,231 & 11,538 & 9,231 & 9,231 & 11,538 & $\begin{array}{r}120,000 \\
0 \\
0\end{array}$ & \\
\hline & Total Monthly Projection & 9,231 & 9,231 & 9,231 & 11,538 & 9,231 & 11,538 & 9,231 & 9,231 & 11,538 & 9,231 & 9,231 & 11,538 & 120,000 & \\
\hline & Projection & 9,2 & 18,462 & 27,692 & 39,231 & 48,462 & 60,000 & 69,231 & 78,462 & 90,000 & 99,231 & 108,462 & $\overline{120,000}$ & & \\
\hline & $\begin{array}{l}\text { Cumulative Costs } \\
\text { Cumulative Costs + Liens }\end{array}$ & $\begin{array}{l}6,660 \\
6,660\end{array}$ & $\begin{array}{l}18,366 \\
18,366\end{array}$ & $\begin{array}{l}28,2,2 \\
28,2\end{array}$ & & & & & & & & & & & \\
\hline \multirow[t]{6}{*}{ 5.2.3.1 } & $\begin{array}{l}\text { Total Form Performance Testing } \\
\text { and Dissolution Modeling } \\
\text { Henry Shaww }\end{array}$ & Oct 00 & Nov 00 & Dec 00 & Jan 01 & Feb 01 & Mar 01 & Apr 01 & May 01 & Jun 01 & Jul 01 & Aug 01 & Sep 01 & Totals & $\begin{array}{l}\text { Cum. } \\
\text { Var. }\end{array}$ \\
\hline & Manpower Projection & 30,769 & 30,769 & 30,769 & 38,462 & 30,769 & 38,462 & 30,769 & 30,769 & 38,462 & 30,769 & 30,769 & 38,462 & 400,000 & \\
\hline & i Procurement Projection & & & 0 & & & & & & & & & & & \\
\hline & 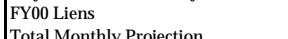 & $\begin{array}{r}0 \\
30769\end{array}$ & $\begin{array}{r}0 \\
30769\end{array}$ & $\begin{array}{r}0 \\
30769\end{array}$ & $\begin{array}{r}0 \\
3846\end{array}$ & $\begin{array}{r}0 \\
30769\end{array}$ & $\begin{array}{r}0 \\
38462\end{array}$ & $\begin{array}{r}0 \\
30769\end{array}$ & $\begin{array}{r}0 \\
30769 \\
-10\end{array}$ & $\begin{array}{r}0 \\
3846\end{array}$ & $\begin{array}{r}0 \\
30769\end{array}$ & $\begin{array}{r}0 \\
3079\end{array}$ & $\begin{array}{r}0 \\
3846\end{array}$ & 400000 & \\
\hline & $\frac{\text { Total Monthly Projection }}{\text { Cumulative Monthly Projection }}$ & $\frac{30,769}{30,769}$ & $\frac{30,769}{61,538}$ & $\frac{30,769}{92,308}$ & $\begin{array}{r}33,862 \\
130,769\end{array}$ & $\begin{array}{r}30,699 \\
161,538\end{array}$ & 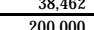 & 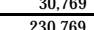 & $\frac{30,69}{261,538}$ & $\frac{38,462}{30000}$ & 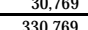 & $\frac{30,769}{361538}$ & 38,4621 & & \\
\hline & $\begin{array}{l}\text { Cumulative Monthly Projection } \\
\text { Cumlative Costs } \\
\text { Cumulative Costs + Liens }\end{array}$ & $\begin{array}{l}30,769 \\
28,001 \\
28,001\end{array}$ & $\begin{array}{l}61,538 \\
65,296 \\
65,296\end{array}$ & $\begin{array}{r}92,308 \\
100,051 \\
100,051\end{array}$ & 130,769 & 161,338 & 200,000 & & 201,230 & & 330,169 & & & & \\
\hline \multirow[t]{6}{*}{ 5.2.3.4 } & $\begin{array}{l}\text { Form Qualification and Repository } \\
\text { Interaction } \\
\text { Henry Shaww }\end{array}$ & Oct 00 & Nov 00 & Dec 00 & Jan 01 & Feb 01 & Mar 01 & Apr 01 & May 01 & Jun 01 & Jul 01 & Aug 01 & Sep 01 & Totals & $\begin{array}{l}\text { Cum. } \\
\text { var. }\end{array}$ \\
\hline & Manpower Projection & 21,083 & 21,083 & 21,083 & 26,354 & 21,083 & 26,354 & 21,083 & 21,083 & 26,354 & 21,083 & 26,354 & 47,000 & 300,000 & \\
\hline & $\begin{array}{l}\text { Major Procurement Projection } \\
\text { FYYo Liens }\end{array}$ & & & & & & & & & & & & & & \\
\hline & thly Projection & 21 & & & 26,3 & 21,083 & & & & 26,354 & 3 & & 47,000 & 300,040 & \\
\hline & ly Projection & & & & 89,644 & 110,728 & 137,082 & 158,165 & 179,248 & 205,603 & 226,686 & 253,040 & 300,040 & & \\
\hline & $\begin{array}{l}\text { Cumulative Costs } \\
\text { Cumulative Costs + Liens }\end{array}$ & $\begin{array}{l}47,667 \\
47,707\end{array}$ & $\begin{array}{l}81,611 \\
81,651\end{array}$ & $\begin{array}{l}111,298 \\
111,388\end{array}$ & & & & & & & & & & & \\
\hline
\end{tabular}

280,000 New FY01 Fund (ommitted C/O 280,000 Total FY01 Funding

120,000 New FY01 Fund 0 Comm.C/O 120,000 Total FY01 Funding

400,000 New FY01 Fund 0 Uncommitted C/O 400,000 Total FY01 Funding

300,000 New FY01 Funds 40 Comm. C/O 300,040 Total FY01 Funding 
LLNL FY01 Spend Plan

5.2.3 D\&T Form Qualification Total Oct $00 \quad$ Nov 00

Dec 00

Jan 01

Feb $01 \quad$ Mar 01

Apr 01

May 01

Jun 01

Jul 01

Aug 01

Sep $01 \quad$ Totals

Manpower Projection
Major Procurement Projection

FY00 Liens

Cotal Monthly Projection

Cumulative Costs

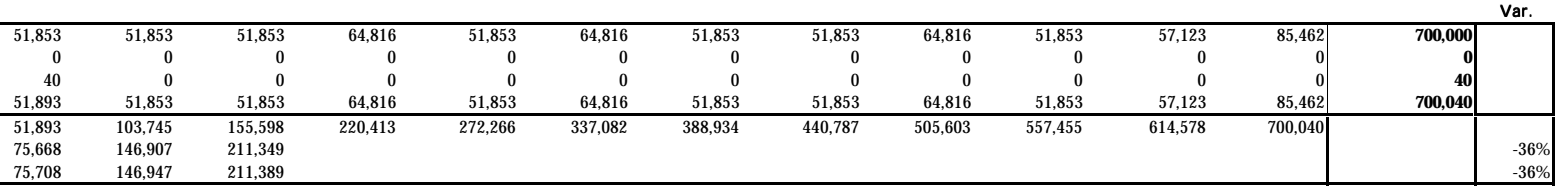

700,000 New FY01 Funds
40 Comm. C/O

40 Comm. C/O
0 Uncommitted C/O

Cumulative Costs + Liens

LLNL Immobilization and
Associated Processing Total

octon

\begin{tabular}{|c|c|c|c|c|c|c|c|c|c|c|c|c|c|c|}
\hline $\begin{array}{l}\text { Associated Processing Total } \\
\text { Lead - Tom Gould }\end{array}$ & Oct 00 & Nov 00 & Dec 00 & Jan 01 & Feb 01 & Mar 01 & Apr 01 & May 01 & Jun 01 & Jul 01 & Aug 01 & Sep 01 & Totals & $\begin{array}{l}\text { Cum. } \\
\text { Var. }\end{array}$ \\
\hline Manpower Projection & $1,543,544$ & $1,902,428$ & $1,326,466$ & $\begin{array}{ll}1,734,049 \\
\end{array}$ & $\begin{array}{ll}1,332,086 \\
\end{array}$ & $\begin{array}{ll}1,285,549 \\
\end{array}$ & 926,186 & 682,486 & 681,149 & 663,186 & 592,457 & 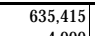 & $13,305,000$ & \\
\hline Major Procurement Projection & 30,000 & 30,000 & 30,000 & 240,000 & 5,000 & 5,000 & 15,000 & 14,000 & 10,000 & 4,000 & 4,000 & 4,000 & 391,000 & \\
\hline FY00 Liens & $\begin{array}{r}950,219 \\
\end{array}$ & & & & & & & & & 0 & $\begin{array}{r}0 \\
59657-20\end{array}$ & & 950,219 & \\
\hline \begin{tabular}{|l} 
Total Monthly Projection \\
\end{tabular} & $2,523,762$ & $1,932,428$ & $1,356,466$ & $1,974,049$ & $1,337,086$ & $1,290,549$ & 941,186 & 696,486 & 691,149 & 667,186 & 596,457 & 639,415 & $14,646,219$ & \\
\hline \begin{tabular}{l|} 
Cumulative Monthly Projection \\
Cumulative Costs
\end{tabular} & $\begin{array}{l}2,523,762 \\
1,240,650\end{array}$ & $\begin{array}{l}4,456,190 \\
3,104,145\end{array}$ & $\begin{array}{l}5,812,656 \\
4,649,220\end{array}$ & $7,786,705$ & $\begin{array}{l}9,123,791 \\
\end{array}$ & $10,414,340$ & $\begin{array}{ll}1,355,526 \\
\end{array}$ & $12,052,012$ & $12,743,161$ & $13,410,347$ & $14,006,804$ & \begin{tabular}{ll|}
$14,646,219$ \\
\end{tabular} & & $20 \%$ \\
\hline $\begin{array}{l}\text { Cumulativive Costs } \\
\text { Cumuls Liens }\end{array}$ & $\begin{array}{l}1,240,050 \\
2,53,248\end{array}$ & $\begin{array}{l}3,104,4,45 \\
4,453,431\end{array}$ & $\begin{array}{l}4,64,9200 \\
6,015,962\end{array}$ & & & & & & & & & & & -3\% \\
\hline
\end{tabular}

13,696,000 New FY01 Funds

0 Uncommitted C/O

0 Funds not allocated
Ot,64,219 Total F01 Funding

Cumulative Costs + Liens

13,696,000 New Funding 


\section{WSRC - Immobilization}

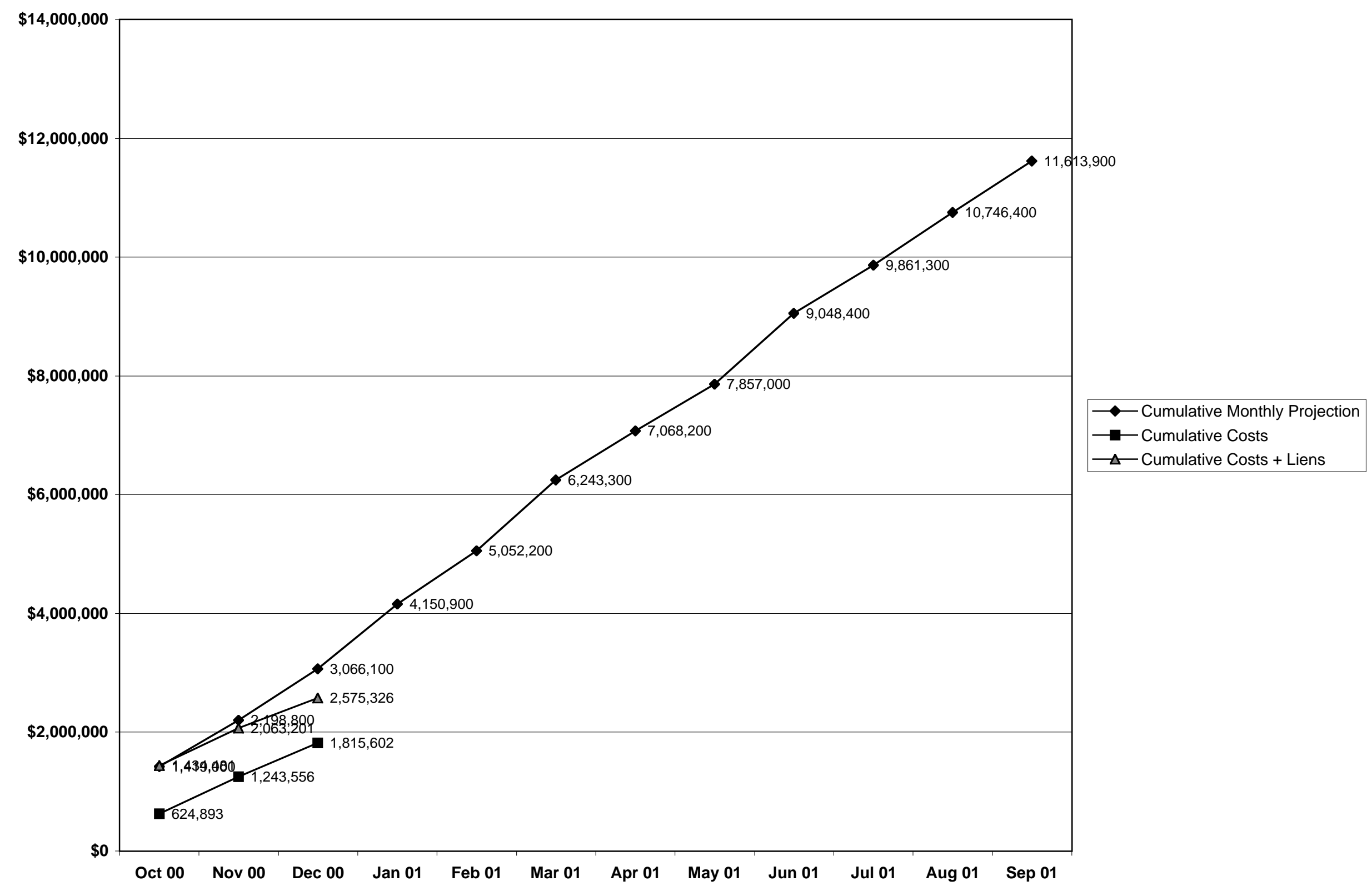


5.1.2 DOCDR

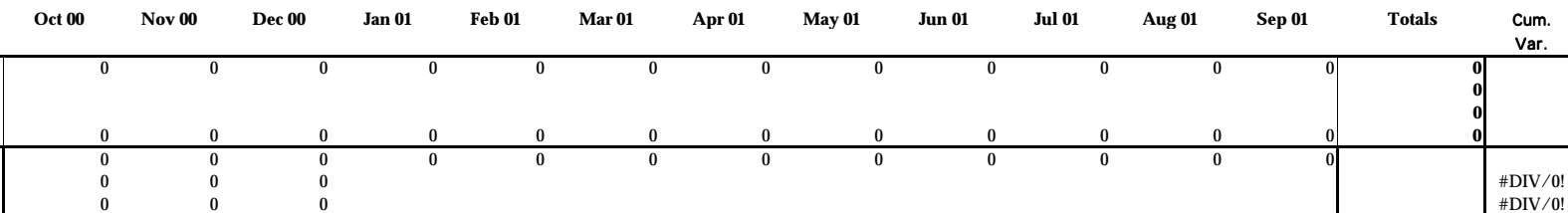

Major Procurement Projection Liens

Total Monthly Projection

Cumulative Monthly Projection

Cumulative Costs
Cumulative Costs + Lien

ঋকक

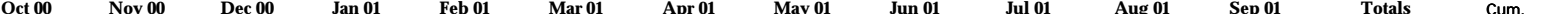

\begin{tabular}{|c|c|c|c|c|c|c|c|c|c|c|c|c|c|c|}
\hline \begin{tabular}{|l|} 
Manpower Projection \\
Major Procurement Projection \\
FY00 Liens \\
Total Monthly Projection
\end{tabular} & 32,000 & 32,000 & 32,000 & 35,000 & 35,000 & 45,000 & 45,000 & 45,000 & 50,000 & 50,000 & 50,000 & $\begin{array}{l}49,000 \\
49,000 \\
\end{array}$ & $\begin{array}{r}500,000 \\
0 \\
0 \\
500,000\end{array}$ & \\
\hline Cumulative Monthly Projection & 32,000 & 64,000 & 96,000 & 131,000 & 166,000 & 211,000 & 256,000 & 301,000 & 351,000 & 401,000 & 451,000 & 500,000 & & \\
\hline $\begin{array}{l}\text { Cumulative Costs } \\
\text { Cumulative Costs + Liens }\end{array}$ & $\begin{array}{l}30,428 \\
30,428\end{array}$ & $\begin{array}{l}69,412 \\
69,412\end{array}$ & $\begin{array}{l}95,452 \\
95,452\end{array}$ & & & & & & & & & & & $1 \%$ \\
\hline
\end{tabular}

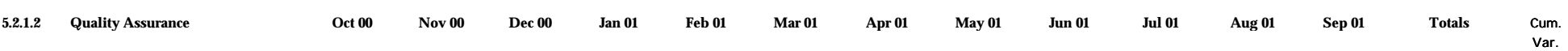

\begin{tabular}{|c|c|c|c|c|c|c|c|c|c|c|c|c|c|c|}
\hline $\begin{array}{l}\text { Manpower Projection } \\
\text { Major Procurement Projection } \\
\text { FY00 Liens }\end{array}$ & $\begin{array}{r}7,700 \\
13,500\end{array}$ & 11,100 & 10,200 & 10,500 & 16,400 & 18,700 & 14,000 & 17,100 & 15,400 & 13,700 & 17,100 & 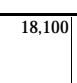 & $\begin{array}{r}170,000 \\
13,500\end{array}$ & \\
\hline $\begin{array}{l}\text { Cumulative Monthly Projection } \\
\text { Cumulative Costs }\end{array}$ & 21,200 & 32,300 & $\begin{array}{l}42,500 \\
37939\end{array}$ & 53,000 & 69,400 & 88,100 & 102,100 & 119,200 & 134,600 & 148,300 & 165,400 & 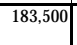 & & $11 \%$ \\
\hline $\begin{array}{l}\text { Cumulative Costs } \\
\text { Cumulative Costs + Liens }\end{array}$ & 63,530 & 84,238 & $\begin{array}{l}37,939 \\
93,491\end{array}$ & & & & & & & & & & & $-120 \%$ \\
\hline
\end{tabular}

500,000 FY00 Funding

0 Comm. C/O
0 Unob C/O

500,000 Total FY00 Funding

Oct $00 \quad$ Nov

Dec $00 \quad$ Ja

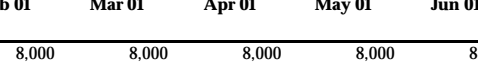

\begin{tabular}{rrr|r|r|}
\hline 8,000 & 8,000 & 6,000 & $\begin{array}{r}100,000 \\
0\end{array}$ & \\
& & & \\
400 & & \\
8,000 & 8,000 & 6,000 & 100,400 & \\
\hline 86,400 & 94,400 & 100,400 & & $2 \%$ \\
& & & $0 \%$ \\
\hline
\end{tabular}

Major Procurement Projectio

FYoo Liens

Cumulative Monthly Projection

Cumulative Costs + Liens

$\begin{array}{rr}12,000 & 10,000 \\ 400 & \\ 12,400 & 10,000 \\ 12,400 & 22,00 \\ 11,481 & 22,86 \\ 11,769 & 23,200\end{array}$

1,000
2,400
2,826
2,210

$\begin{array}{rrrrrrrr}8,000 & 8,000 & 8,000 & 8,000 & 8,000 & 8,000 & 8,000 & 8,00 \\ & & & & & & & \\ 8,000 & 8,000 & 8,000 & 8,000 & 8,000 & 8,000 & 8,000 & 8,000 \\ 8,400 & 38,400 & 46,400 & 54,400 & 62,400 & 70,400 & 78,400 & 86,40 \\ 2,878 & & & & & & & \\ , 262 & & & & & & & \end{array}$

Oct $00 \quad$ Nov $00 \quad$ Dec 00

Jan $01 \quad$ Feb $01 \quad$ Mar 01

$\begin{array}{llr}\text { Jul } 01 & \text { Aug } 01 & \text { Sep } 01\end{array}$

\begin{tabular}{|c|c|c|c|c|c|c|c|c|c|c|c|c|c|c|}
\hline Manpower Projection & 51,700 & 53,100 & 50,200 & 53,500 & 59,400 & $\overline{71,700}$ & 67,000 & 70,100 & 73,400 & 71,700 & 75,100 & $\overline{73,100}$ & 770,000 & \\
\hline Major Procurement Projection & 0 & & & & & 0 & & & 0 & & 0 & & & \\
\hline Cumulative Monthly Projection & 65,600 & $\frac{3,1800}{118,700}$ & 168,900 & 222,400 & 281,800 & $\frac{1,100}{353,500}$ & 420,500 & 490,600 & 564,000 & 635,700 & 710,800 & $\frac{|r, 1000|}{783,900 \mid}$ & & \\
\hline $\begin{array}{l}\text { Cumulative Costs } \\
\text { Cumulative Costs + Liens }\end{array}$ & $\begin{array}{r}153,000 \\
53,639 \\
105727\end{array}$ & $\begin{array}{l}11,150 \\
115,976 \\
17686\end{array}$ & $\begin{array}{l}160,269 \\
163,269\end{array}$ & & & & & & & & & & & \% \\
\hline
\end{tabular}

170,000 FY00 Funding

13,500 Comm. C/O
0 Unob C/O

183,500 Total FY00 Funding

100,000 FY00 Funding

400 Comm. C/O
0 Unob C/O

100,400 Total FY00 Funding

770,000 FY00 Funding

13,900 Comm. C/O

783,900 Total FY00 Funding

«\%

5.2.2.1.1 Feed Materials Characterization and
Blending

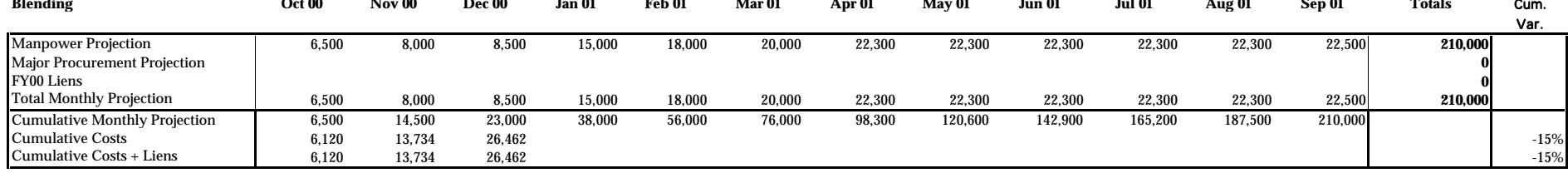




\begin{tabular}{|c|c|c|c|c|c|c|c|c|c|c|c|c|c|c|c|c|}
\hline 5.2.2.1.2 & Proliferation Resistance & Oct 00 & Nov 00 & Dec 00 & Jan 01 & Feb 01 & Mar 01 & Apr 01 & May 01 & Jun 01 & Jul 01 & Aug 01 & Sep 01 & Totals & $\begin{array}{l}\text { Cum. } \\
\text { Var. }\end{array}$ & \\
\hline & \begin{tabular}{|l|} 
Manpower Projection \\
Major Procurement Projection \\
FYYo Liens \\
Total Monthly Projection \\
\end{tabular} & 0 & 0 & 0 & 0 & 0 & 0 & 0 & 0 & 0 & 0 & 0 & 0 & $\begin{array}{l} \\
0 \\
0 \\
0 \\
\end{array}$ & & $\begin{array}{l}0 \text { FY00 Funding } \\
0 \text { Comm. C/O } \\
0 \text { Unob C/O } \\
0 \text { Total FY00 Funding }\end{array}$ \\
\hline & $\begin{array}{l}\text { Cumulative Monthly Projection } \\
\text { Cumulative Costs } \\
\text { Cumulative Costs + Liens }\end{array}$ & $\begin{array}{l}0 \\
0 \\
0\end{array}$ & $\begin{array}{l}0 \\
0 \\
0\end{array}$ & $\begin{array}{l} \\
0 \\
0 \\
0\end{array}$ & 0 & 0 & 0 & 0 & 0 & 0 & 0 & 0 & & & $\begin{array}{l}\text { \#DIV/0! } \\
\text { \#DIV/0! }\end{array}$ & \\
\hline \multirow[t]{3}{*}{ 5.2.2.1.3 } & $\begin{array}{l}\text { System Integration and Cross- } \\
\text { cutting Functions }\end{array}$ & Oct 00 & Nov 00 & Dec 00 & Jan 01 & Feb 01 & Mar 01 & Apr 01 & May 01 & Jun 01 & Jul 01 & Aug 01 & Sep 01 & Totals & $\begin{array}{l}\text { Cum. } \\
\text { Var. }\end{array}$ & \multirow{3}{*}{$\begin{array}{l}\text { 510,000 FY00 Funding } \\
\text { 0 Comm. C/O } \\
\text { 0 Unob C/O } \\
\text { 510,000 Total FY00 Funding }\end{array}$} \\
\hline & \begin{tabular}{|l} 
Manpower Projection \\
Major Procurement Projection \\
FYoo Liens \\
Total Monthly Projection
\end{tabular} & $\begin{array}{lll}101,000 \\
\end{array}$ & 93,000 & 83,000 & 58,000 & 68,000 & 77,000 & $\begin{array}{l}30,000 \\
30,000\end{array}$ & 0 & 0 & 0 & 0 & 0 & $\begin{array}{r}510,000 \\
0 \\
0 \\
510,000\end{array}$ & & \\
\hline & $\begin{array}{l}\text { Cumulative Monthly Projection } \\
\text { Cumulative Costs } \\
\text { Cumulative Costs + Liens }\end{array}$ & $\begin{array}{l}101,000 \\
101,741 \\
101,741 \\
\end{array}$ & $\begin{array}{r}194,000 \\
192,793 \\
192,793 \\
\end{array}$ & $\begin{array}{l}277,000 \\
270,237 \\
270,237 \\
\end{array}$ & 335,000 & 403,000 & 480,000 & 50,0000 & 510,000 & 510,000 & 510,000 & 510,000 & 510,000 & & $\begin{array}{l}2 \% \\
2 \% \\
\end{array}$ & \\
\hline \multirow[t]{3}{*}{ 5.2.2.1.4. } & Material Transport & Oct 00 & Nov 00 & Dec 00 & Jan 01 & Feb 01 & Mar 01 & Apr 01 & May 01 & Jun 01 & Jul 01 & Aug 01 & Sep 01 & Totals & $\begin{array}{l}\text { Cum. } \\
\text { Var. }\end{array}$ & \multirow{3}{*}{$\begin{array}{l}\text { 60,000 FY00 Funding } \\
0 \text { Conm. C/O } \\
\text { 0 Unob C/O } \\
60,000 \text { Total FY00 Funding }\end{array}$} \\
\hline & \begin{tabular}{|l} 
Manpower Projection \\
Major Procurement Projection \\
FYoo Liens \\
Total Monthly Projection
\end{tabular} & 0 & 3,000 & 3,000 & 3,000 & 5,000 & 5,000 & 5,000 & 10,000 & 10,000 & 8,000 & 4,000 & \begin{tabular}{|c|}
4,000 \\
\end{tabular} & $\begin{array}{r}60,000 \\
0 \\
0 \\
60,000\end{array}$ & & \\
\hline & \begin{tabular}{|l|} 
Cumulative Monthly Projection \\
Cumulative Costs \\
Cumulative Costs + Liens \\
\end{tabular} & $\begin{array}{l}0 \\
0 \\
0\end{array}$ & $\begin{array}{l}3,000 \\
1,597 \\
1,597\end{array}$ & $\begin{array}{l}6,000 \\
6,077 \\
6,077\end{array}$ & 9,000 & 14,000 & 19,000 & 24,000 & 34,000 & 44,000 & 52,000 & 56,000 & 60,000 & & $\begin{array}{l}-1 \% \\
-1 \%\end{array}$ & \\
\hline \multirow[t]{4}{*}{ 5.2.2.1.5 } & Waste Handling System & Oct 00 & Nov 00 & Dec 00 & Jan 01 & Feb 01 & Mar 01 & Apr 01 & May 01 & Jun 01 & Jul 01 & Aug 01 & Sep 01 & Totals & $\begin{array}{l}\text { Cum. } \\
\text { Var. }\end{array}$ & \multirow{4}{*}{$\begin{array}{l}\text { 110,000 FY00 Funding } \\
\text { 0 Comm. C/O } \\
\text { 0 Unob C/O } \\
\text { 110,000 Total FY00 Funding }\end{array}$} \\
\hline & \begin{tabular}{|l} 
Manpower Projection \\
Major Procurement Projection \\
FYoo Liens \\
Total Monthly Projection
\end{tabular} & 5,500 & 4,500 & 4,000 & 6,000 & 12,000 & 12,000 & 16,000 & 10,000 & 10,000 & 10,000 & 10,000 & \begin{tabular}{ll|}
10,000 \\
\end{tabular} & $\begin{array}{r}110,000 \\
0 \\
0 \\
110,000\end{array}$ & & \\
\hline & Cumulative Monthly Projection & 5,500 & 10,000 & 14,000 & 20,000 & 32,000 & 44,000 & 60,000 & 70,000 & 8 & 90,000 & 100000 & 10 & & & \\
\hline & $\begin{array}{l}\text { Cumulative Costs } \\
\text { Cumulative Costs + Liens }\end{array}$ & $\begin{array}{l}5,399 \\
5,399\end{array}$ & $\begin{array}{l}6,134 \\
6,134\end{array}$ & $\begin{array}{l}10,636 \\
10,636\end{array}$ & & & & & & & & & & & $24 \%$ & \\
\hline \multirow[t]{7}{*}{ 5.2.2.1 } & $\begin{array}{l}\text { Technical Support \& Integration } \\
\text { Total }\end{array}$ & Oct 00 & Nov 00 & Dec 00 & Jan 01 & Feb 01 & Mar 01 & Apr 01 & May 01 & Jun 01 & Jul 01 & Aug 01 & Sep 01 & Totals & $\begin{array}{l}\text { Cum. } \\
\text { Var. }\end{array}$ & \multirow{7}{*}{$\begin{array}{l}\text { 890,000 FY00 Funding } \\
\text { 0 Comm. C/O } \\
\text { 0 Unob C/O } \\
\text { 890,000 Total FY00 Funding }\end{array}$} \\
\hline & Manpower Projection & 113,000 & 108,500 & 98,500 & 82,000 & 103,000 & 114,000 & 73,300 & 42,300 & 42,300 & 40,300 & 36,300 & 36,500 & 890,000 & & \\
\hline & Major Procurement Projection & & & & & & & & & & & & & & & \\
\hline & & & & & & & & & & & & & & 0 & & \\
\hline & Total Monthly Projection & 113,000 & 108,500 & 98,500 & 82,000 & 103,000 & 114,000 & 73,300 & 42,300 & 42,300 & 40,300 & 36,300 & 36,500 & 890,000 & & \\
\hline & Cumulative Monthly Projection & 113,000 & 221,500 & 320,000 & 402,000 & 505,000 & 619,000 & 692,300 & 734,600 & 776,900 & 817,200 & 853,500 & 890,000 & & & \\
\hline & $\begin{array}{l}\text { Cumulative Costs } \\
\text { Cumulative Costs + Liens }\end{array}$ & $\begin{array}{l}113,260 \\
113260\end{array}$ & $\begin{aligned} 214,258 \\
214258\end{aligned}$ & $\begin{array}{l}313,412 \\
3134212\end{array}$ & & & & & & & & & & & $\begin{array}{l}2 \% \\
2 \%\end{array}$ & \\
\hline \multirow{6}{*}{ 5.2.2.2.2.3. } & & & & & & & & & & & & & & & & \multirow{6}{*}{$\begin{array}{l}\text { 342,000 FY00 Funding } \\
\text { 2,000 Comm. C/O } \\
\text { 0 Unob C/O } \\
\text { 344,000 Total FY00 Funding }\end{array}$} \\
\hline & Development & Oct 00 & Nov 00 & Dec 00 & Jan 01 & Feb 01 & Mar 01 & Apr 01 & May 01 & Jun 01 & Jul 01 & Aug 01 & Sep 01 & Totals & $\begin{array}{l}\text { Cum. } \\
\text { Var. }\end{array}$ & \\
\hline & \begin{tabular}{|l} 
Manpower Projection \\
Major Procurement Projection \\
FYO0 Liens
\end{tabular} & $\begin{array}{r}34,700 \\
2,000\end{array}$ & 49,100 & 34,300 & 36,300 & 49,100 & 54,800 & 10,300 & 16,200 & 13,700 & 11,000 & 16,200 & \begin{tabular}{|c|c|}
16,300 \\
\end{tabular} & $\begin{array}{r}342,000 \\
0 \\
2,000\end{array}$ & & \\
\hline & Total Monthly Projection & 36,700 & 49,100 & 34,300 & 36,300 & 49,100 & 54,800 & 10,300 & 16,200 & 13,700 & 11,000 & 16,200 & 16,300 & 344,000 & & \\
\hline & Monthly Projection & 36,700 & 85,800 & 120,100 & 156,400 & 205,500 & 260,300 & 270,600 & 286,800 & 300,500 & 311,500 & 327,700 & 344,000 & & & \\
\hline & \begin{tabular}{|l} 
Cumulative Costs \\
Cumulative Costs + Liens
\end{tabular} & $\begin{array}{l}22,097 \\
35,097\end{array}$ & $\begin{array}{l}45,313 \\
55,978\end{array}$ & $\begin{array}{l}88,882 \\
88,882\end{array}$ & & & & & & & & & & & $26 \%$ & \\
\hline \multirow[t]{6}{*}{ 5.2.2.2. } & $\begin{array}{l}\text { Immobilized Form Development } \\
\text { Total }\end{array}$ & Oct 00 & Nov 00 & Dec 00 & Jan 01 & Feb 01 & Mar 01 & Apr 01 & May 01 & Jun 01 & Jul 01 & Aug 01 & Sep 01 & Totals & $\begin{array}{l}\text { Cum. } \\
\text { Var. }\end{array}$ & \multirow{6}{*}{$\begin{array}{l}\text { 342,000 FY00 Funding } \\
\text { 2,000 Comm. C/O } \\
\text { 0 Unob C/O } \\
\text { 344,000 Total FY00 Funding }\end{array}$} \\
\hline & Manpower Projection & 34,700 & 49,100 & 34,300 & 36,300 & 49,100 & 54,800 & 10,300 & 16,200 & 13,700 & 11,000 & 16,200 & \begin{tabular}{|l|l|}
16,300 \\
\end{tabular} & 342,000 & & \\
\hline & $\begin{array}{l}\text { Major Procurement Projection } \\
\text { FY00 Liens }\end{array}$ & & & 0 & & & 0 & & & 0 & & & $\begin{array}{l}0 \\
0\end{array}$ & 2000 & & \\
\hline & $\begin{array}{l}\text { Fooulens } \\
\text { Total Monthly Projection }\end{array}$ & $\begin{array}{l}2,000 \\
36,700\end{array}$ & 49,100 & 34,300 & 36,300 & 49,100 & 54,800 & 10,300 & 16,200 & 13,700 & 11,000 & 16,200 & 16,300 & 344,000 & & \\
\hline & Cumulative Monthly Projection & 36,700 & 85,800 & 120,100 & 156,400 & 205,500 & 260,300 & 270,600 & 286,800 & 300,500 & 311,500 & 327,700 & 00 & & & \\
\hline & $\begin{array}{l}\text { Cumulative Costs } \\
\text { Cumulative Costs + Liens }\end{array}$ & $\begin{array}{l}22,0,097 \\
35,097\end{array}$ & $\begin{array}{l}45,333 \\
5,978\end{array}$ & $\begin{array}{l}88,882 \\
88,882\end{array}$ & & & & & & & & & & & $26 \%$ & \\
\hline
\end{tabular}

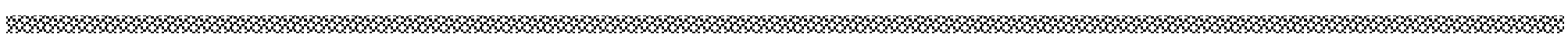




\begin{tabular}{|c|c|c|c|c|c|c|c|c|c|c|c|c|c|c|c|c|}
\hline 5.2.2.2.1 & Material Receipt \& Storage & Oct 00 & Nov 00 & Dec 00 & Jan 01 & Feb 01 & Mar 01 & Apr 01 & May 01 & Jun 01 & Jul 01 & Aug 01 & Sep 01 & Totals & Cum. & \multirow{4}{*}{$\begin{array}{l}55,000 \text { FY00 Funding } \\
0 \text { Comm. C/O } \\
0 \text { Unob C/O } \\
55,000 \text { Total FY00 Funding }\end{array}$} \\
\hline & \begin{tabular}{|l|} 
Manpower Projection \\
Major Procurement Projection \\
FYoo Liens \\
Total Monthly Projection
\end{tabular} & 0 & 5,000 & 5,000 & 5,000 & 5,000 & 5,000 & 5,000 & 5,000 & 5,000 & 5,000 & 5,000 & 5,000 & \begin{tabular}{r|}
55,000 \\
0 \\
0
\end{tabular} & & \\
\hline & & 0 & 5,000 & 5,000 & 5,000 & 5,000 & 5,000 & 5,000 & 5,000 & 5,000 & 5,000 & 5,000 & 5,000 & & & \\
\hline & \begin{tabular}{|l} 
Cumulative Monthly Projection \\
Cumulative Costs \\
Cumulative Costs + Liens
\end{tabular} & $\begin{array}{l}0 \\
0 \\
0\end{array}$ & $\begin{array}{l}5,000 \\
2,771 \\
2,701\end{array}$ & $\begin{array}{l}10,000 \\
10,066 \\
10,066\end{array}$ & 15,000 & 20,000 & 25,000 & 30,000 & 35,000 & 40,000 & 45,000 & 50,000 & 55,000 & & $\begin{array}{l}-1 \% \\
-1 \%\end{array}$ & \\
\hline \multirow[t]{4}{*}{ 5.2.2.3.3 } & Material Size Reduction & Oct 00 & Nov 00 & Dec 00 & Jan 01 & Feb 01 & Mar 01 & Apr 01 & May 01 & Jun 01 & Jul 01 & Aug 01 & Sep 01 & Totals & $\begin{array}{l}\text { Cum. } \\
\text { Var. }\end{array}$ & \multirow{5}{*}{$\begin{array}{l}\text { 30,000 FY00 Funding } \\
0 \text { Comm. C/O } \\
\text { O Unob C/O } \\
\text { 30,000 Total FY00 Funding }\end{array}$} \\
\hline & \begin{tabular}{|l} 
Manpower Projection \\
Major Procurement Projection \\
FFOo Liens \\
Total Monthly Projection \\
\end{tabular} & 0 & 0 & 7,500 & 7,500 & 7,500 & 7,500 & 0 & 0 & 0 & 0 & 0 & & \begin{tabular}{r|r|}
30,000 \\
0 \\
0 \\
30,000 \\
\end{tabular} & & \\
\hline & \begin{tabular}{|l|} 
Cumulative Monthly Projection \\
Cumulative Costs
\end{tabular} & 0 & 0 & 7,500 & 15,000 & 22,500 & 30,000 & 30,000 & 30,000 & 30,000 & 30,000 & 30,000 & 30,000 & & & \\
\hline & $\begin{array}{l}\text { Lumuantve Costs } \\
\text { Cumulative Costs + Liens }\end{array}$ & 0 & 0 & 0 & & & & & & & & & & & $\begin{array}{l}100 \% \\
100 \%\end{array}$ & \\
\hline \multirow[t]{4}{*}{ 5.2.2.3.4 } & Material Unpacking and Sorting & Oct 00 & Nov 00 & Dec 00 & Jan 01 & Feb 01 & Mar 01 & Apr 01 & May 01 & Jun 01 & Jul 01 & Aug 01 & Sep 01 & Totals & $\begin{array}{l}\text { Cum. } \\
\text { Var. }\end{array}$ & \\
\hline & \begin{tabular}{|l} 
Manpower Projection \\
Major Procurement Projection \\
FYOo Liens \\
Total Monthly Projection
\end{tabular} & 10,000 & 7,600 & 9,600 & 14,600 & 15,600 & 16,000 & 9,600 & 7,600 & 9,600 & 7,600 & 9,600 & $7,600 \mid$ & \begin{tabular}{r|r|}
125,000 \\
0 \\
0 \\
125,000
\end{tabular} & & \multirow[t]{4}{*}{$\begin{array}{l}125,000 \text { FYoo Funding } \\
0 \text { Comm. C/O } \\
0 \text { Unob C/O } \\
125,000 \text { Total FYOo Funding }\end{array}$} \\
\hline & Cumulative Monthly Projection & 10,000 & 17,600 & 27,200 & 41,800 & 57,400 & 73,400 & 83,000 & 90,600 & 100,200 & 107,800 & 117,400 & $125,000 \mid$ & & & \\
\hline & $\begin{array}{l}\text { Cumulative Costs } \\
\text { Cumulative Costs + Liens }\end{array}$ & $\begin{array}{l}9,587 \\
9,587\end{array}$ & $\begin{array}{l}16,002 \\
16,002\end{array}$ & $\begin{array}{l}22,791 \\
22,791\end{array}$ & & & & & & & & & & & $\begin{array}{l}16 \% \\
16 \%\end{array}$ & \\
\hline \multirow[t]{4}{*}{ 5.2.2.2.3.6 } & Metal Conversion & Oct 00 & Nov 00 & Dec 00 & Jan 01 & Feb 01 & Mar 01 & Apr 01 & May 01 & Jun 01 & Jul 01 & Aug 01 & Sep 01 & Totals & $\begin{array}{l}\text { Cum. } \\
\text { Var. }\end{array}$ & \\
\hline & \begin{tabular}{|l|} 
Manpower Projection \\
Major Procurement Projection \\
FYoo Liens \\
Total Monthly Projection
\end{tabular} & 0 & 10,000 & 10,000 & 0 & 0 & 0 & 0 & 0 & 0 & 0 & 0 & & \begin{tabular}{r|r|}
20,000 \\
0 \\
0 \\
20,000
\end{tabular} & & \multirow[t]{4}{*}{$\begin{array}{l}\text { 20,000 FY00 Funding } \\
\text { 0 Comm. C/O } \\
\text { 0 Unob C/O } \\
\text { 20,000 Total FY00 Funding }\end{array}$} \\
\hline & Cumulative Monthly Projection & 0 & 10,000 & 20,000 & 20,000 & 20,000 & 20,000 & 20,000 & 20,000 & 20,000 & 20,000 & 20,000 & 20,000 & & & \\
\hline & $\begin{array}{l}\text { Cumulative Costs } \\
\text { Cumulative Costs + Liens }\end{array}$ & $\begin{array}{l}0 \\
0\end{array}$ & $\begin{array}{l}0 \\
0\end{array}$ & $\begin{array}{l}0 \\
0 \\
\end{array}$ & & & & & & & & & & & $\begin{array}{l}100 \% \\
100 \%\end{array}$ & \\
\hline \multirow[t]{4}{*}{ 5.2.2.2.3.7 } & Impure Oxide Feed Preparation & Oct 00 & Nov 00 & Dec 00 & Jan 01 & Feb 01 & Mar 01 & Apr 01 & May 01 & Jun 01 & Jul 01 & Aug 01 & Sep 01 & Totals & $\begin{array}{l}\text { Cum. } \\
\text { Var. }\end{array}$ & \\
\hline & \begin{tabular}{|l} 
Manpower Projection \\
Major Procurement Projection \\
FYoo Liens \\
Total Monthly Projection
\end{tabular} & 0 & 10,000 & 10,000 & 0 & 0 & 0 & 0 & 0 & 0 & 0 & 0 & & \begin{tabular}{r|r|}
20,000 \\
0 \\
0 \\
20,000
\end{tabular} & & \multirow{3}{*}{$\begin{array}{l}\text { 20,000 FY00 Funding } \\
\text { O Comm. C/O } \\
\text { O Unob C/O } \\
\text { 20,000 Total FY00 Funding }\end{array}$} \\
\hline & \begin{tabular}{|l|} 
Cumulative Monthly Projection \\
Cumulative Costs
\end{tabular} & $\begin{array}{l}0 \\
0 \\
0\end{array}$ & $\begin{aligned} 10,000 \\
0\end{aligned}$ & $\begin{array}{l}20,000 \\
11,051\end{array}$ & 20,000 & 20,000 & 20,000 & 20,000 & 20,000 & 20,000 & 20,000 & 20,000 & 20,000 & & & \\
\hline & Cumulative Costs + Liens & 0 & 0 & 11,051 & & & & & & & & & & & $45 \%$ & \\
\hline \multirow[t]{4}{*}{ 5.2.2.3.8 } & Materials Characterization & Oct 00 & Nov 00 & Dec 00 & Jan 01 & Feb 01 & Mar 01 & Apr 01 & May 01 & Jun 01 & Jul 01 & Aug 01 & Sep 01 & Totals & $\begin{array}{l}\text { Cum. } \\
\text { Var. }\end{array}$ & \multirow{6}{*}{$\begin{array}{l}\text { 240,000 FY00 Funding } \\
0 \text { Comm. C/O } \\
\text { 0 Unob C/O } \\
\text { 240,000 Total FYO0 Funding }\end{array}$} \\
\hline & $\begin{array}{l}\text { Manpower Projection } \\
\text { Major Procurement Projection } \\
\text { FYOo Liens } \\
\text { Total Monthly Projection }\end{array}$ & 14,200 & 21,100 & 17,100 & 12,100 & 22,100 & 22,100 & 15,800 & 21,100 & 19,200 & 16,700 & 20,000 & 38,500 & $\begin{aligned} 240,000 \\
0 \\
0 \\
240,000\end{aligned}$ & & \\
\hline & \begin{tabular}{|l} 
Iotal Monthyly Projection \\
Cumulative Monthly Projection
\end{tabular} & 14,200 & 35,300 & 52,400 & 64,500 & 86,600 & 108,700 & 124,500 & 145,600 & 164,800 & 181,500 & 201,500 & $\frac{5,0,000}{240,000}$ & & & \\
\hline & & 13,270 & 30,166 & 43,426 & & & & & & & & & & & 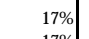 & \\
\hline \multirow{5}{*}{ 5.2.2.3.9 } & Material Control \&-Accontability & Oct 00 & Noven & $\operatorname{Dec} \theta 0$ & Jan 11 & Feb 01 & Mar 01 & Anr 01 & Mav01 & Jun 01 & Jul 01 & Aug 01 - Y & Sen 01 & Totals & & \\
\hline & Material Control \& Accountability & Oct vo & Nov 0o & Dec vo & 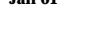 & revor & Maror & Aprov & May or & Jaror & 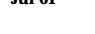 & Augor & sepoi & & Var. & \\
\hline & $\begin{array}{l}\text { Manpowere Projection } \\
\text { Major Procurement Projection } \\
\text { FTO0 Liens } \\
\text { Total Monthly Projection }\end{array}$ & 0 & 0 & 0 & 5,000 & 5,000 & 6,000 & 6,000 & 0 & 0 & 0 & 0 & 0 & $\begin{array}{r}22,000 \\
0 \\
0 \\
22,000\end{array}$ & & \multirow[t]{3}{*}{$\begin{array}{l}\text { 22,000 FY00 Funding } \\
0 \text { Comm. C/O } \\
\text { O Unob C/O } \\
\text { 22,000 Total FY00 Funding }\end{array}$} \\
\hline & $\frac{\text { Total Monthly Projection }}{\text { Cumulative Monthly Projection }}$ & 0 & 0 & 0 & 5,000 & 10,000 & 16,000 & 22,000 & 22,000 & 22,000 & 22,000 & 22,000 & $\frac{0}{000}$ & & & \\
\hline & $\begin{array}{l}\text { Cumulative Costs } \\
\text { Cumulative Costs + Liens }\end{array}$ & $\begin{array}{l}0 \\
0\end{array}$ & $\begin{array}{l}0 \\
0\end{array}$ & $\begin{array}{l}0 \\
0\end{array}$ & & & & & & & & & & & \#DIV $/ 0 !$ & \\
\hline
\end{tabular}


5.2.2.3.10 In-Process Storage Vault

$\begin{array}{lllll}\text { Oct } 00 & \text { Nov } 00 & \text { Dec } 00 & \text { Jan } 01 & \text { Feb } 01\end{array}$

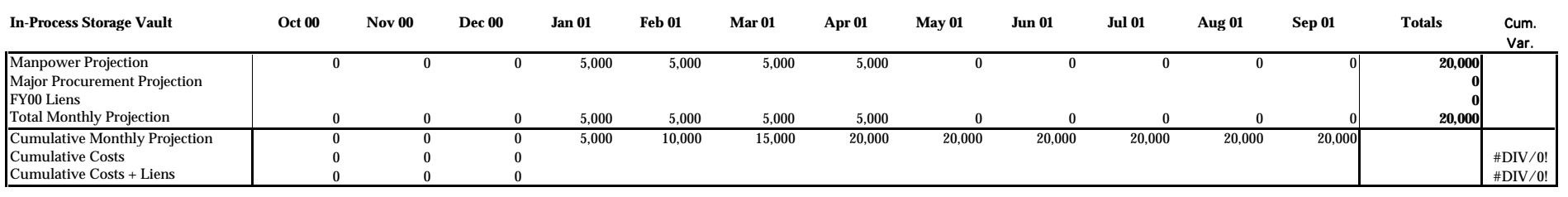

Cumulative Costs + Lien

Pu Conversion Process/Equipmen
Development Total

\begin{tabular}{|c|c|c|c|c|c|c|c|c|c|c|c|c|c|c|}
\hline & & & & & & . & & . & 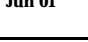 & 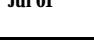 & 0 & Prot & 列 & $\begin{array}{l}\text { Cum. } \\
\text { Var. }\end{array}$ \\
\hline $\begin{array}{l}\text { Cumulative Monthly Projection } \\
\text { Cumulative Costs }\end{array}$ & $\begin{array}{l}24,200 \\
22,857\end{array}$ & $\begin{array}{l}77,900 \\
48,869\end{array}$ & $\begin{array}{r}137,100 \\
87,334\end{array}$ & 186,300 & 244,500 & 308,100 & 349,500 & 383,200 & 417,000 & 446,300 & 480,900 & 532,000 & & $36 \%$ \\
\hline
\end{tabular}

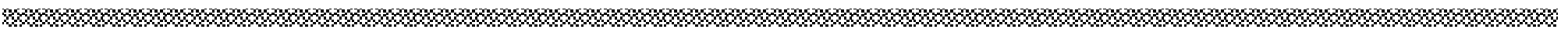

\begin{tabular}{|c|c|c|c|c|c|c|c|c|c|c|c|c|c|c|c|c|}
\hline 5.2.2.4.1 & Ceramic Feed Batching & Oct 00 & Nov 00 & Dec 00 & Jan 01 & Feb 01 & Mar 01 & Apr 01 & May 01 & Jun 01 & Jul 01 & Aug 01 & Sep 01 & Totals & Cum. & \multirow{4}{*}{$\begin{array}{l}\text { 470,000 FY00 Funding } \\
0 \text { Comm. C/O } \\
\text { 0 Unob C/O } \\
\text { 470,000 Total FY00 Funding }\end{array}$} \\
\hline & \begin{tabular}{|l} 
Manpower Projection \\
Major Procurement Projection \\
FYo0 Liens
\end{tabular} & 13,400 & 39,200 & 39,700 & 32,200 & 42,200 & 58,100 & 47,300 & 45,200 & 41,700 & 33,900 & 41,800 & 35,300 & $\begin{array}{r}470,000 \\
0 \\
0\end{array}$ & & \\
\hline & Total Monthly Projection & 13,400 & 39,200 & 39,700 & 32,200 & 42,200 & 58,100 & 47,300 & 45,200 & 41,700 & 33,900 & 41,800 & 35,300 & & & \\
\hline & \begin{tabular}{|l|} 
Cumulative Monthly Projection \\
Cumulative Costs \\
Cumulative Costs + Liens \\
\end{tabular} & $\begin{array}{l}13,400 \\
12,797 \\
12779\end{array}$ & $\begin{array}{l}52,600 \\
29,551 \\
2955\end{array}$ & $\begin{array}{l}92,300 \\
47,574 \\
4757\end{array}$ & 124,500 & 166,700 & 224,800 & 272,100 & 317,300 & 359,000 & 392,900 & 434,700 & 470,000 & & 48\% & \\
\hline \multirow[t]{4}{*}{ 5.2.2.4.2.2.1 } & $\begin{array}{l}\text { Ceramification Process } \\
\text { Development }\end{array}$ & Oct 00 & Nov 00 & Dec 00 & Jan 01 & Feb 01 & Mar 01 & Apr 01 & May 01 & Jun 01 & Jul 01 & Aug 01 & Sep 01 & Totals & $\begin{array}{l}\text { Cum. } \\
\text { Var. }\end{array}$ & \multirow{5}{*}{$\begin{array}{l}0 \text { FY00 Funding } \\
0 \text { Comm. C/O } \\
0 \text { Unob C/O } \\
0 \text { Total FY00 Funding }\end{array}$} \\
\hline & \begin{tabular}{|l|} 
Manpower Projection \\
Major Procurement Projection \\
FYoo Liens \\
Total Monthly Projection
\end{tabular} & 0 & 0 & 0 & 0 & 0 & 0 & 0 & 0 & 0 & 0 & $\overline{0}$ & & $\begin{array}{l}0 \\
0 \\
0 \\
0\end{array}$ & & \\
\hline & Cumulative Monthly Projection & 0 & 0 & 0 & 0 & 0 & 0 & 0 & 0 & 0 & 0 & 0 & & & & \\
\hline & $\begin{array}{l}\text { Cumulative Costs } \\
\text { Cumulative Costs + Liens }\end{array}$ & $\begin{array}{l}0 \\
0\end{array}$ & $\begin{array}{l}0 \\
0\end{array}$ & $\begin{array}{l}0 \\
0\end{array}$ & & & & & & & & & & & \#DIV /0! & \\
\hline \multirow[t]{5}{*}{ 5.2.2.4.2.2.3 } & $\begin{array}{l}\text { Ceramification Prototype Test } \\
\text { Facility (CPTF) }\end{array}$ & Oct 00 & Nov 00 & Dec 00 & Jan 01 & Feb 01 & Mar 01 & Apr 01 & May 01 & Jun 01 & Jul 01 & Aug 01 & Sep 01 & Totals & $\begin{array}{l}\text { Cum. } \\
\text { Var. }\end{array}$ & \\
\hline & \begin{tabular}{|l|} 
Manpower Projection \\
Major Procurement Projection \\
FY00 Liens
\end{tabular} & $\begin{array}{l}281,500 \\
457,300\end{array}$ & 320,700 & 400,400 & 678,000 & 297,100 & 470,800 & 302,800 & 338,300 & 761,300 & 429,400 & 439,700 & 395,000 & $\begin{array}{r}5,115,000 \\
0 \\
457,300\end{array}$ & & \multirow[t]{4}{*}{$\begin{array}{l}\text { 5,115,000 FY00 Funding } \\
\text { 457,300 Comm. C/O } \\
\text { 0 Unob C/O } \\
5,572,300 \text { Total FY00 Funding }\end{array}$} \\
\hline & Total Monthly Projection & 738,800 & 320,700 & 400,400 & 678,000 & 297,100 & 470,800 & 302,800 & 338,300 & 761,300 & 429,400 & 439,700 & 395,000 & $5,572,300$ & & \\
\hline & Cumulative Monthly Projection & 738,800 & $1,059,500$ & $1,459,900$ & $2,137,900$ & $2,435,000$ & $2,905,800$ & $3,208,600$ & $3,546,900$ & $4,308,200$ & $4,737,600$ & $5,177,300$ & 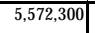 & & & \\
\hline & \begin{tabular}{|l} 
Cumulativiv Costs \\
Cumulative Costs + Liens
\end{tabular} & $\begin{array}{l}263,915 \\
72,215\end{array}$ & $\begin{array}{l}522,441 \\
968,988\end{array}$ & $\begin{array}{r}751,385 \\
1,180,475\end{array}$ & & & & & & & & & & & $\begin{array}{l}49 \% \\
19 \%\end{array}$ & \\
\hline \multirow[t]{5}{*}{ 5.2.2.4.2.2.2 } & $\begin{array}{l}\text { Plutonium Ceramic Test Facility } \\
\text { (PuCTF) }\end{array}$ & Oct 00 & Nov 00 & Dec 00 & Jan 01 & Feb 01 & Mar 01 & Apr 01 & May 01 & Jun 01 & Jul 01 & Aug 01 & Sep 01 & Totals & Cum. & \multirow{6}{*}{$\begin{array}{l}\text { 480,000 FY00 Funding } \\
0 \text { Comm. C/O } \\
0 \text { Unob C/O } \\
480,000 \text { Total FY00 Funding }\end{array}$} \\
\hline & \begin{tabular}{|l|} 
Manpower Projection \\
Major Procurement Projection \\
FYo Liens
\end{tabular} & 30,000 & 37,000 & 37,000 & 37,000 & 37,000 & 37,000 & 37,000 & 37,000 & 37,000 & 37,000 & 37,000 & 80,000 & $\begin{aligned} 480,000 \\
0 \\
0\end{aligned}$ & & \\
\hline & Total Monthly Projection & 30,000 & 37,000 & 37,000 & 37,000 & 37,000 & 37,000 & 37,000 & 37,000 & 37,000 & 37,000 & 37,000 & 80,000 & 480,000 & & \\
\hline & Cumulative Monthly Projection & 30,000 & 67,000 & 104,000 & 141,000 & 178,000 & 215,000 & 252,000 & 289,000 & 326,000 & 363,000 & 400,000 & 480,000 & & & \\
\hline & $\begin{array}{l}\text { Cumulative Costs } \\
\text { Cumulative Costs + Liens }\end{array}$ & $\begin{array}{l}28,875 \\
28,875\end{array}$ & 56,977 & $\begin{array}{l}83,939 \\
83,939\end{array}$ & & & & & & & & & & & $19 \%$ & \\
\hline \multirow[t]{5}{*}{ 5.2.2.4.3. } & $\begin{array}{l}\text { Puck NDE/MC\&A for Process } \\
\text { Control and SNM Accountability }\end{array}$ & Oct 00 & Nov 00 & Dec 00 & Jan 01 & Feb 01 & Mar 01 & Apr 01 & May 01 & Jun 01 & Jul 01 & Aug 01 & Sep 01 & Totals & $\begin{array}{l}\text { Cum. } \\
\text { Var. }\end{array}$ & \\
\hline & $\begin{array}{l}\text { Manpower Projection } \\
\text { Major Procurement Projection } \\
\text { FY00 Liens }\end{array}$ & $\begin{array}{r}5,500 \\
245,700\end{array}$ & 25,100 & 48,900 & 41,200 & 111,900 & 123,300 & 79,800 & 117,500 & 100,400 & 83,000 & 115,900 & 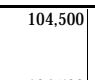 & $\begin{array}{r}557,000 \\
245 \\
245,700\end{array}$ & & \multirow{4}{*}{$\begin{array}{l}\text { 957,000 FY00 Funding } \\
\text { 245,700 Comm. C C O } \\
\text { O Unob C/O } \\
\text { 1,202,700 Total FY00 Funding }\end{array}$} \\
\hline & Total Monthly Projection & 251,200 & 25,100 & 48,900 & 41,200 & 111,900 & 123,300 & 79,800 & 117,500 & 100,400 & 83,000 & 115,900 & 104,500 & $1,202,700$ & & \\
\hline & \begin{tabular}{|l|} 
Cumulative Monthly Projection \\
Cumulative Costs
\end{tabular} & $\begin{array}{r}251,200 \\
5,372\end{array}$ & $\begin{array}{r}276,300 \\
20,481\end{array}$ & $\begin{array}{r}325,200 \\
37,399\end{array}$ & 366,400 & 478,300 & 601,600 & 681,400 & 798,900 & 899,300 & 982,300 & $1,098,200$ & $\begin{array}{ll}1,202,700 \\
\end{array}$ & & $88 \%$ & \\
\hline & Cumulative Costs + Liens & 251,072 & 266,181 & 283,099 & & & & & & & & & & & $13 \%$ & \\
\hline
\end{tabular}




\begin{tabular}{|c|c|c|c|c|c|c|c|c|c|c|c|c|c|c|c|c|}
\hline 5.2.2.4.5 & Can Loading & Oct 00 & Nov 00 & Dec 00 & Jan 01 & Feb 01 & Mar 01 & Apr 01 & May 01 & Jun 01 & Jul 01 & Aug 01 & Sep 01 & Totals & $\begin{array}{l}\text { Cum. } \\
\text { Var. }\end{array}$ & \multirow{4}{*}{$\begin{array}{l}\text { 382,000 FY00 Funding } \\
0 \text { Comm. C/O } \\
0 \text { Unob C C O } \\
382,000 \text { Total FY00 Funding }\end{array}$} \\
\hline & \begin{tabular}{|l} 
Manpower Projection \\
Major Procurement Projection \\
FYoo Liens \\
Total Monthly Projection
\end{tabular} & 40,800 & $\begin{array}{r}27,900 \\
27,900\end{array}$ & 34,400 & 27,900 & $\begin{array}{r}28,900 \\
28,900\end{array}$ & $\begin{array}{r}6,500 \\
36,500\end{array}$ & $\begin{array}{l}29,900 \\
29,900\end{array}$ & $\begin{array}{l}28,900 \\
28,900\end{array}$ & $\begin{array}{l}34,400 \\
34,400\end{array}$ & $\begin{array}{l}28,900 \\
28,900\end{array}$ & $\begin{array}{l}35,500 \\
35,500 \\
\end{array}$ & $\begin{array}{r}28,000 \\
28,000 \\
\end{array}$ & $\begin{array}{r}382,000 \\
0 \\
0 \\
382,000\end{array}$ & & \\
\hline & Cumulative Monthly Projection & 40,800 & 68,700 & 103,100 & 131,000 & 159,900 & 196,400 & 226,300 & 255,200 & 289,600 & 318,500 & 354,000 & 382,000 & & & \\
\hline & $\begin{array}{l}\text { Cumulative Costs } \\
\text { Cumulative Costs + Liens } \\
\end{array}$ & $\begin{array}{l}41,141 \\
41,141 \\
\end{array}$ & $\begin{array}{l}75,622 \\
75,622 \\
\end{array}$ & $\begin{array}{l}97,617 \\
97,617 \\
\end{array}$ & & & & & 200,200 & 207,000 & & $50,0,00$ & & & $5 \%$ & \\
\hline \multirow[t]{4}{*}{ 5.2.2.4.4.6 } & Can MC\&A & Oct 00 & Nov 00 & Dec 00 & Jan 01 & Feb 01 & Mar 01 & Apr 01 & May 01 & Jun 01 & Jul 01 & Aug 01 & Sep 01 & Totals & $\begin{array}{l}\text { Cum. } \\
\text { Var. }\end{array}$ & \multirow{4}{*}{$\begin{array}{l}\text { 109,000 FY00 Funding } \\
0 \text { Comm. C/O } \\
\text { 0 Unob C/O } \\
\text { 109,000 Total FY00 Funding }\end{array}$} \\
\hline & \begin{tabular}{|l} 
Manpower Projection \\
Major Procurement Projection \\
FYoo Liens \\
Total Monthly Projection
\end{tabular} & 4,000 & 7,300 & 8,200 & 7,300 & 12,300 & 14,100 & 11,800 & 11,300 & 9,100 & 7,300 & $\begin{array}{l}9,000 \\
9,000\end{array}$ & 7,300 & $\begin{array}{r}109,000 \\
0 \\
0 \\
109,000 \\
\end{array}$ & & \\
\hline & Cumulative Monthly Projection & 4,000 & 11,300 & 19,500 & 26,800 & 39,100 & 53,200 & 65,000 & 76,300 & 85,400 & 92,700 & 101,700 & 109,000 & & & \\
\hline & $\begin{array}{l}\text { Cumulative Costs } \\
\text { Cumulative Costs + Liens }\end{array}$ & $\begin{array}{l}3,935 \\
3,935 \\
\end{array}$ & $\begin{array}{l}6,307 \\
6,307 \\
\end{array}$ & $\begin{array}{l}7,304 \\
7,304\end{array}$ & & & & & & & & & & & $\begin{array}{l}63 \% \\
63 \%\end{array}$ & \\
\hline \multirow[t]{3}{*}{ 5.2.2.4 } & $\begin{array}{l}\text { First Stage Immobilization Process/ } \\
\text { Equip Development Total }\end{array}$ & Oct 00 & Nov 00 & Dec 00 & Jan 01 & Feb 01 & Mar 01 & Apr 01 & May 01 & Jun 01 & Jul 01 & Aug 01 & Sep 01 & Totals & $\begin{array}{l}\text { Cum. } \\
\text { Var. }\end{array}$ & \multirow{3}{*}{$\begin{array}{l}\text { 7,513,000 FY00 Funding } \\
\text { 703,000 Comm. C/O } \\
\text { 0 Unob C/O } \\
\text { 8,216,000 Total FY00 Funding }\end{array}$} \\
\hline & \begin{tabular}{|l|} 
Manpower Projection \\
Major Procurement Projection \\
FYo0 Liens \\
Total Monthly Projection
\end{tabular} & $\begin{array}{r}375,200 \\
0 \\
703,000 \\
1,078,200\end{array}$ & $\begin{array}{r}457,200 \\
0 \\
0 \\
457,200\end{array}$ & $\begin{array}{r}568,600 \\
0 \\
0 \\
568,600\end{array}$ & $\begin{array}{r}823,600 \\
0 \\
0 \\
823,600\end{array}$ & $\begin{array}{r}529,400 \\
0 \\
0 \\
529,400\end{array}$ & $\begin{array}{r}739,800 \\
0 \\
0 \\
739,800\end{array}$ & $\begin{array}{r}508,600 \\
0 \\
0 \\
508,600\end{array}$ & $\begin{array}{r}578,200 \\
0 \\
0 \\
578,200\end{array}$ & $\begin{array}{r}983,900 \\
0 \\
0 \\
983,900\end{array}$ & $\begin{array}{r}619,500 \\
0 \\
0 \\
619,500\end{array}$ & $\begin{array}{r}678,900 \\
0 \\
0 \\
678,900\end{array}$ & $\begin{array}{r}650,100 \\
0 \\
0 \\
650,100\end{array}$ & $\begin{array}{r}7,513,000 \\
0 \\
703,000 \\
8,216,000\end{array}$ & & \\
\hline & $\begin{array}{l}\text { Cumulative Monthly Projection } \\
\text { Cumulative Costs } \\
\text { Cumulative Costs + Liens }\end{array}$ & $\begin{array}{r}1,078,200 \\
356,035 \\
1,050,035\end{array}$ & $\begin{array}{r}1,535,400 \\
711,179 \\
1,403,626\end{array}$ & $\begin{array}{l}2,104,000 \\
1,025,218 \\
1,700,008\end{array}$ & $2,927,600$ & $3,457,000$ & 4,196,800 & $4,705,400$ & $5,283,600$ & $6,267,500$ & $6,887,000$ & $7,565,900$ & $|8,216,000|$ & & $\begin{array}{l}51 \% \\
19 \%\end{array}$ & \\
\hline & 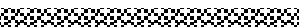 & 1040 & $\$ 40$ & $\infty$ & & & & & & & & & & & & \\
\hline \multirow[t]{4}{*}{ 5.2.2.5.1.1 } & $\begin{array}{l}\text { Can-in-Canister Design and } \\
\text { Assembly }\end{array}$ & Oct 00 & Nov 00 & Dec 00 & Jan 01 & Feb 01 & Mar 01 & Apr 01 & May 01 & Jun 01 & Jul 01 & Aug 01 & Sep 01 & Totals & $\begin{array}{l}\text { Cum. } \\
\text { Var. }\end{array}$ & \multirow{5}{*}{$\begin{array}{l}\text { 200,000 FY00 Funding } \\
\text { 0 Comm. C C O } \\
\text { 0 Unob C/O } \\
\text { 200,000 Total FY00 Funding }\end{array}$} \\
\hline & \begin{tabular}{|l|} 
Manpower Projection \\
Major Procurement Projection \\
FYoo Liens \\
Total Monthly Projection
\end{tabular} & 26,000 & 16,000 & 16,000 & 16,000 & 16,000 & 16,000 & 16,000 & 16,000 & 16,000 & 16,000 & $\begin{array}{l}16,000 \\
16,000\end{array}$ & \begin{tabular}{r|}
14,000 \\
14,000
\end{tabular} & $\begin{array}{r}200,000 \\
0 \\
0 \\
200,000\end{array}$ & & \\
\hline & Cumulative Monthly Projection & 26,000 & 42,000 & 58,000 & 74,000 & 90,000 & 106,000 & 122,000 & 138,000 & 154,000 & 170,000 & 186,000 & 200,000 & & & \\
\hline & $\begin{array}{l}\text { Cumulative Costs } \\
\text { Cumulative Costs + Liens }\end{array}$ & $\begin{array}{l}26,482 \\
26,482\end{array}$ & $\begin{array}{l}42,803 \\
48,152\end{array}$ & $\begin{array}{l}58,784 \\
62,782\end{array}$ & & & & & & & & & & & $\begin{array}{l}-1 \% \\
-8 \%\end{array}$ & \\
\hline \multirow[t]{4}{*}{ 5.2.2.5.1.2. } & Canister Pour Analysis and Testing & Oct 00 & Nov 00 & Dec 00 & Jan 01 & Feb 01 & Mar 01 & Apr 01 & May 01 & Jun 01 & Jul 01 & Aug 01 & Sep 01 & Totals & $\begin{array}{l}\text { Cum. } \\
\text { Var. }\end{array}$ & \\
\hline & \begin{tabular}{|l|} 
Manpower Projection \\
Major Procurement Projection \\
FYo Liens
\end{tabular} & $\begin{array}{l}23,000 \\
43,000\end{array}$ & 23,000 & 20,000 & 10,000 & 5,000 & 5,000 & 5,000 & 3,000 & 3,000 & 3,000 & 0 & & $\begin{array}{r}100,000 \\
0 \\
43,000\end{array}$ & & \multirow{3}{*}{$\begin{array}{l}\text { 100,000 FY00 Funding } \\
\text { 43,000 Comm. C/O } \\
\text { 0 Unob C/O } \\
\text { 143,000 Total FY00 Funding }\end{array}$} \\
\hline & Total Monthly Projection & 66,000 & 23,000 & 20,000 & 10,000 & 5,000 & 5,000 & 5,000 & 3,000 & 3,000 & 3,000 & 0 & 0 & 143,000 & & \\
\hline & \begin{tabular}{|l|} 
Cumulative Monthly Projection \\
Cumulative Costs \\
Cumulative Costs + Liens
\end{tabular} & $\begin{array}{l}66,000 \\
21,728 \\
63,228\end{array}$ & $\begin{array}{l}89,000 \\
38,361 \\
88,861\end{array}$ & $\begin{array}{r}109,000 \\
45,626 \\
70,626\end{array}$ & 119,000 & 124,000 & 129,000 & 134,000 & 137,000 & 140,000 & 143,000 & 143,000 & 143,000 & & $58 \%$ & \\
\hline \multirow[t]{4}{*}{ 5.2.2.5.1.3 } & Can/Magazine Storage Vault & Oct 00 & Nov 00 & Dec 00 & Jan 01 & Feb 01 & Mar 01 & Apr 01 & May 01 & Jun 01 & Jul 01 & Aug 01 & Sep 01 & Totals & $\begin{array}{l}\text { Cum. } \\
\text { Var. }\end{array}$ & \multirow{4}{*}{$\begin{array}{l}\text { 55,000 FY00 Funding } \\
\text { 0 Comm. C/O } \\
\text { 0 Unob C/O } \\
55,000 \text { Total FYY0 Funding }\end{array}$} \\
\hline & \begin{tabular}{|l|} 
Manpower Projection \\
Major Procurement Projection \\
FYoo Liens \\
Total Monthly Projection
\end{tabular} & 0 & 0 & 0 & 0 & 0 & 7,000 & 8,000 & 8,000 & 8,000 & 8,000 & 8,000 & 8,000 & $\begin{array}{r}55,000 \\
0 \\
0 \\
55,000\end{array}$ & & \\
\hline & Cumulative Monthly Projection & 0 & 0 & & 0 & 0 & $\frac{7,000}{7,000}$ & $\frac{0,000}{15,000}$ & $\frac{0,000}{23,000}$ & 31,000 & $\frac{0,000}{39,000}$ & $\frac{0,000}{47,000}$ & $\frac{0,000}{55,000}$ & & & \\
\hline & $\begin{array}{l}\text { Cumulative Costs } \\
\text { Cumulative Costs + Liens }\end{array}$ & $\begin{array}{l}0 \\
0\end{array}$ & $\begin{array}{l}613 \\
613\end{array}$ & $\begin{array}{l}613 \\
613\end{array}$ & & & & & & & & & & & $\begin{array}{l}\text { \#DIV } / 0 ! \\
\text { \#DIV } / 0 !\end{array}$ & \\
\hline \multirow[t]{6}{*}{ 5.2.2.5 } & $\begin{array}{l}\text { Second Stage Immobilization } \\
\text { Process/Equip Development Total }\end{array}$ & Oct 00 & Nov 00 & Dec 00 & Jan 01 & Feb 01 & Mar 01 & Apr 01 & May 01 & Jun 01 & Jul 01 & Aug 01 & Sep 01 & Totals & $\begin{array}{l}\text { Cum. } \\
\text { Var. }\end{array}$ & \multirow{6}{*}{$\begin{array}{l}\text { 355,000 FY00 Funding } \\
43,000 \text { Comm. C/O } \\
\text { 0 Unob C C O } \\
\text { 398,000 Total FY00 Funding }\end{array}$} \\
\hline & Manp & 49,000 & 39,000 & 36,000 & 26,000 & 21,000 & 28,000 & 29,000 & 27,000 & 27,000 & 27,000 & 24,000 & 22,000 & 355,000 & & \\
\hline & ent Projection & & & & 0 & & 0 & & & & & & & & & \\
\hline & FY & & & & & & 00 & 29000 & 27000 & 27000 & 2700 & 24.000 & 22000 & $\begin{array}{r}43,000 \\
398,00\end{array}$ & & \\
\hline & $\begin{array}{l}\text { Total Monthly Projection } \\
\text { Cumulative Monthly Projection } \\
\text { Cumulative Costs } \\
\text { Cumulative Costs L Liens }\end{array}$ & $\begin{array}{l}92,000 \\
92,000 \\
48,210\end{array}$ & $\begin{array}{r}39,000 \\
131,000 \\
81,777\end{array}$ & $\begin{array}{l}36,000 \\
16,7000 \\
105,023\end{array}$ & $\begin{array}{r}26,000 \\
193,000\end{array}$ & $\begin{array}{r}21,000 \\
214,000\end{array}$ & $\begin{array}{r}28,000 \\
242,000\end{array}$ & $\begin{array}{r}29,000 \\
271,000\end{array}$ & $\begin{array}{r}27,000 \\
298,000\end{array}$ & $\begin{aligned} 27,000 \\
325,000\end{aligned}$ & $\begin{array}{r}27,000 \\
352,000\end{array}$ & $\begin{array}{r}24,000 \\
376,000\end{array}$ & $\begin{aligned} 22,000 \mid \\
398,000\end{aligned}$ & & \% & \\
\hline & Cumulative Costs + Liens & 89,710 & 137,626 & 134,021 & & & & & & & & & & & & \\
\hline
\end{tabular}

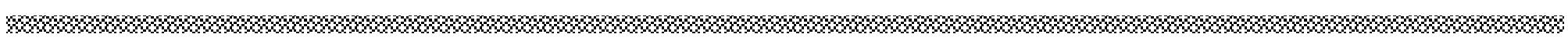




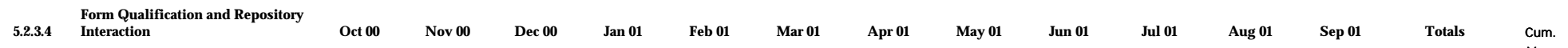

\begin{tabular}{|c|c|c|c|c|c|c|c|c|c|c|c|c|c|c|}
\hline \begin{tabular}{|l} 
Manpower Projection \\
Major Procurement Projection \\
FYo0 Liens \\
Total Monthly Projection
\end{tabular} & 9,300 & 19,200 & 15,500 & 9,200 & 19,200 & 21,200 & 15,300 & 21,300 & 17,300 & 14,100 & 20,000 & $\begin{array}{c}18,400 \\
18,400\end{array}$ & $\begin{array}{r}200,000 \\
0 \\
0 \\
200,000\end{array}$ & \\
\hline Cumulative Monthly Projection & 9,300 & 28,500 & 44,000 & 53,200 & 72,400 & 93,600 & 108,900 & 130,200 & 147,500 & 161,600 & 181,600 & 200,000 & & \\
\hline $\begin{array}{l}\text { Cumulative Costs } \\
\text { Cumulative Costs + Liens }\end{array}$ & $\begin{array}{l}8,795 \\
8795\end{array}$ & 25,371 & 29,623 & & & & & & & & & & & 33\% \\
\hline
\end{tabular}

200,000 FY00 Funding

0 Comm. C/O
0 Unob C/O

200,000 Total FY00 Funding

5.2.3 D\&T Form Oulifion

Nov $00 \quad$ Dec

Jan $01 \quad$ Feb 01

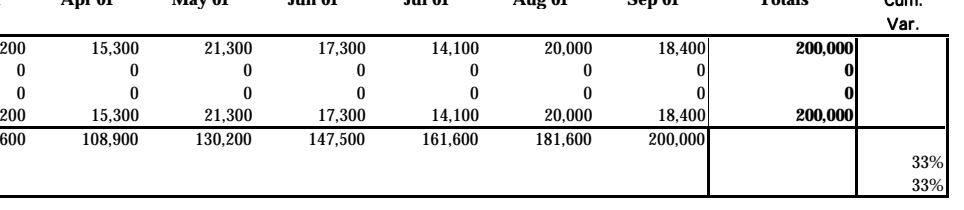

200,000 FY00 Funding

0 Comm. C/O
0 Unob C/O

200,000 Total FY00 Funding

FY00 Liens

Cotal Monthly Projection

Cumulative Costs
Cumulative Costs + Liens \begin{tabular}{rrrr}
0 & 0 & 0 & \\
9,300 & 19,200 & 15,500 & 9,20 \\
\hline 9,300 & 28,500 & 44,000 & 53,20
\end{tabular} \begin{tabular}{lll}
8,795 & 25,371 & 29,623 \\
8,795 & 25,371 & 29,623 \\
\hline
\end{tabular}

\begin{tabular}{rr}
0 & \\
19,200 & 21,200 \\
\hline 72,400 & 93,600
\end{tabular}

\%ळ\%क\%

5.3.1 D\&T Technology Transfer Oct $00 \quad$ Nov $00 \quad$ Dec 00

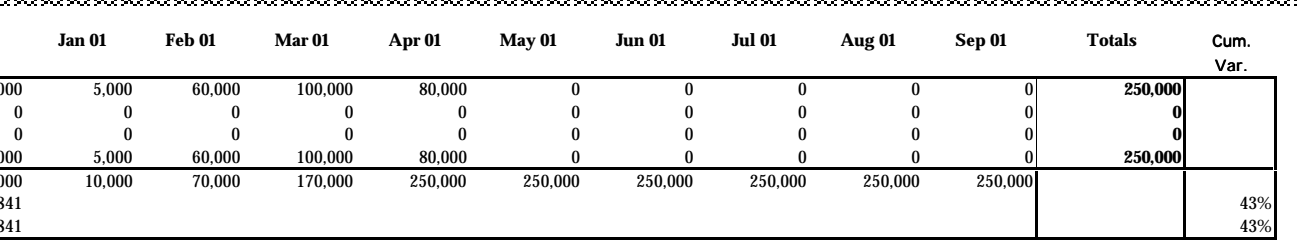

250,000 FY00 Funding

0 Unob C/O
250,000 Total FY00 Funding

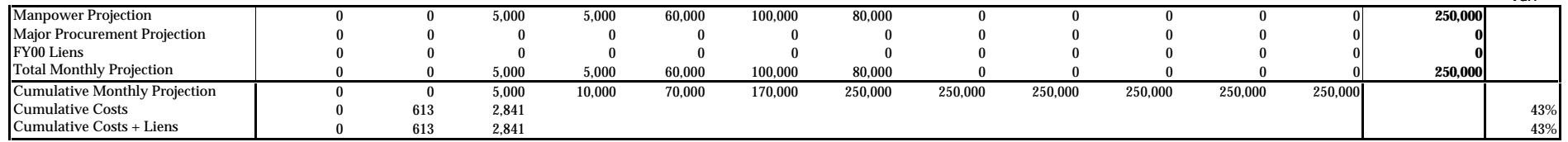

WSRC Immobilization and

Oct $00 \quad$ Nov $00 \quad$ Dec 00

Jan $01 \quad$ Feb 01

Mar 01

Apr $01 \quad$ May 01

Jun 01

Jul 01

Aug $01 \quad$ Sep 01

Totals Cum.

Manpower Projection
Major Procurement Projection

FY00 Liens
Total Monthly Projection

Cumulative Monthly Projection

Cumulative Costs
Cumulative Costs + Liens

\begin{tabular}{|c|c|c|c|c|c|c|c|c|c|c|c|c|c|}
\hline $\begin{array}{r}657,100 \\
0\end{array}$ & $\begin{array}{r}779,800 \\
0\end{array}$ & $\begin{array}{r}867,300 \\
0\end{array}$ & $\begin{array}{r}1,084,800 \\
0\end{array}$ & & $\begin{array}{r}, 191,100 \\
0\end{array}$ & & & $\begin{array}{r}1,191,400 \\
0\end{array}$ & $\begin{array}{r}812,900 \\
0\end{array}$ & & \begin{tabular}{r|r|}
867,500 \\
0
\end{tabular} & $\begin{array}{r}10,852,000 \\
0\end{array}$ & \\
\hline 761,900 & & & & & & & & & & & & 761,900 & \\
\hline$\frac{1,419,000}{1,419,000}$ & $\begin{array}{r}779,800 \\
2,198,800\end{array}$ & $\begin{array}{r}867,300 \\
3,066,100\end{array}$ & $\begin{array}{l}1,084,800 \\
4,150,900\end{array}$ & $\begin{array}{r}901,300 \\
5,052,200\end{array}$ & $\frac{1,191,100}{6,243,300}$ & $\begin{array}{r}824,900 \\
7,068,200\end{array}$ & $\begin{array}{r}7888,800 \\
7,857,000\end{array}$ & $\frac{1,191,400}{9,048,400}$ & $\frac{812,900}{9,861,300}$ & $\begin{array}{r}885,100 \\
10,746,400\end{array}$ & $\begin{array}{r}867,500 \mid \\
11,613,900 \mid\end{array}$ & $11,13,100$. & \\
\hline $\begin{array}{r}1,117,24,803 \\
1,434,481 \\
1,48\end{array}$ & $\begin{array}{l}2,1,240,500 \\
2,063,201\end{array}$ & $\begin{array}{l}3,0001,100 \\
2,57,602 \\
2,55,326\end{array}$ & & & & & & & & & & & $16 \%$ \\
\hline
\end{tabular}


CLEMSON - Immobilization

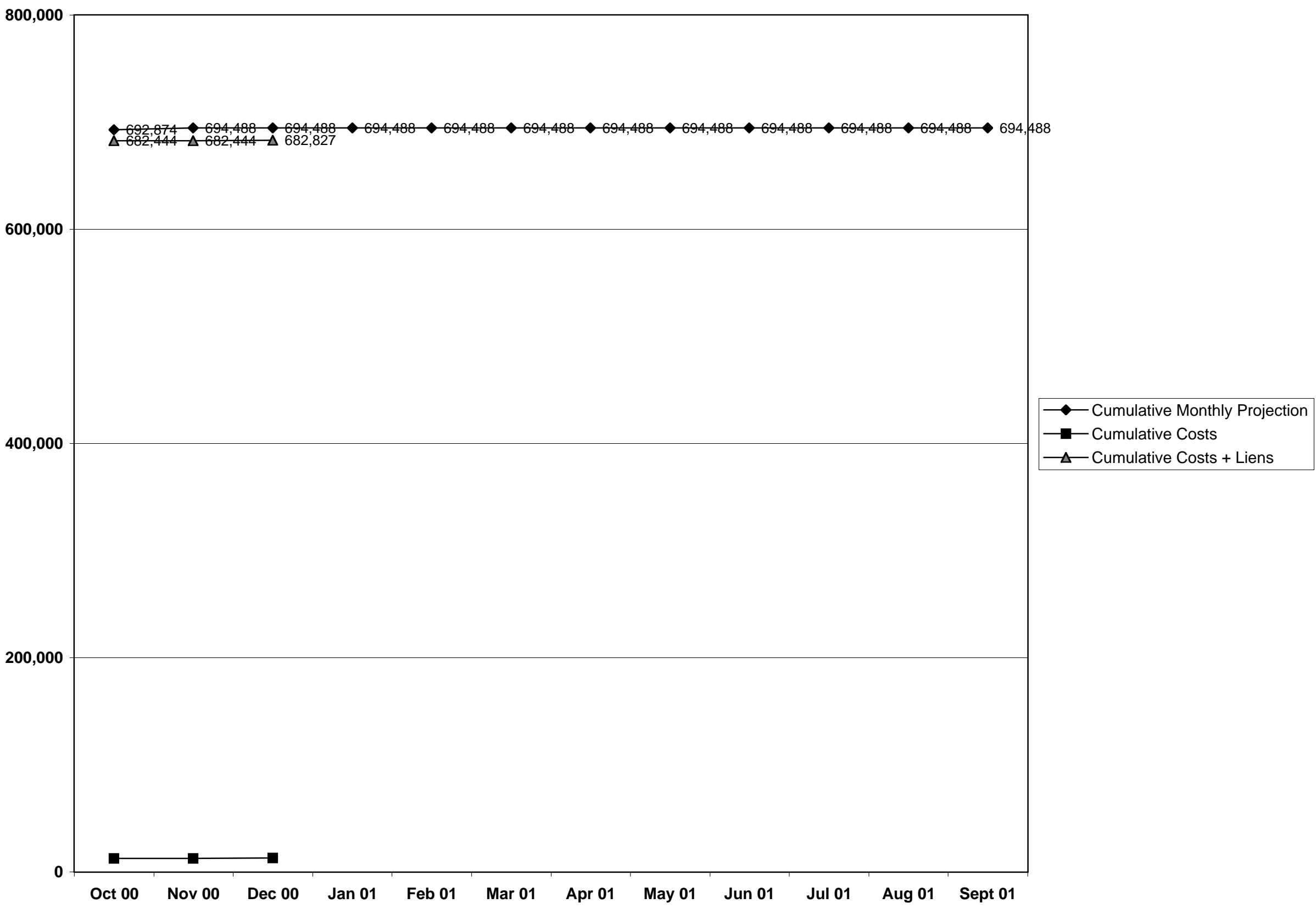


Clemson FY01 Spend Plan

Ceramic Prototypic Test Facility

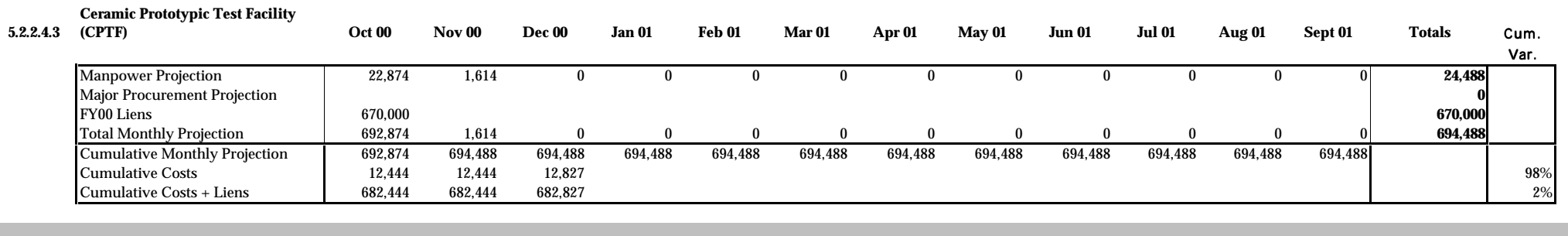

\begin{tabular}{|c|c|c|c|c|c|c|c|c|c|c|c|c|c|c|}
\hline TOTAL - CLEMSON & Oct 00 & Nov 00 & Dec 00 & Jan 01 & Feb 01 & Mar 01 & Apr 01 & May 01 & Jun 01 & Jul 01 & Aug 01 & Sept 01 & Totals & $\begin{array}{l}\text { Cum. } \\
\text { Var. }\end{array}$ \\
\hline Manpower Projection & 22,874 & 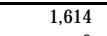 & 0 & 0 & 0 & 0 & 0 & 0 & 0 & 0 & 0 & 0 & 24,488 & \\
\hline Major Procurement Projection & & 0 & 0 & 0 & 0 & 0 & 0 & 0 & 0 & 0 & 0 & & & \\
\hline FY00 Liens & 670,000 & 0 & 0 & 0 & 0 & 0 & 0 & 0 & 0 & 0 & 0 & 0 & 670,000 & \\
\hline Total Monthly Projection & 692,874 & 1,614 & 0 & 0 & 0 & 0 & 0 & 0 & 0 & 0 & 0 & 0 & 694,488 & \\
\hline Cumulative Monthly Projection & 692,874 & 694,488 & 694,488 & 694,488 & 694,488 & 694,488 & 694,488 & 694,488 & 694,488 & 694,488 & 694,488 & $694,488 \mid$ & & \\
\hline Cumulative Costs & 12,444 & 12,444 & 12,827 & & & & & & & & & & & $98 \%$ \\
\hline Cumulative Costs + Liens & 682,444 & 682,444 & 682,827 & & & & & & & & & & & $2 \%$ \\
\hline
\end{tabular}

0 FY01 Funding 24,488 Unob C/O

694,488 Total FY01 Funding 
ANL - Immobilization

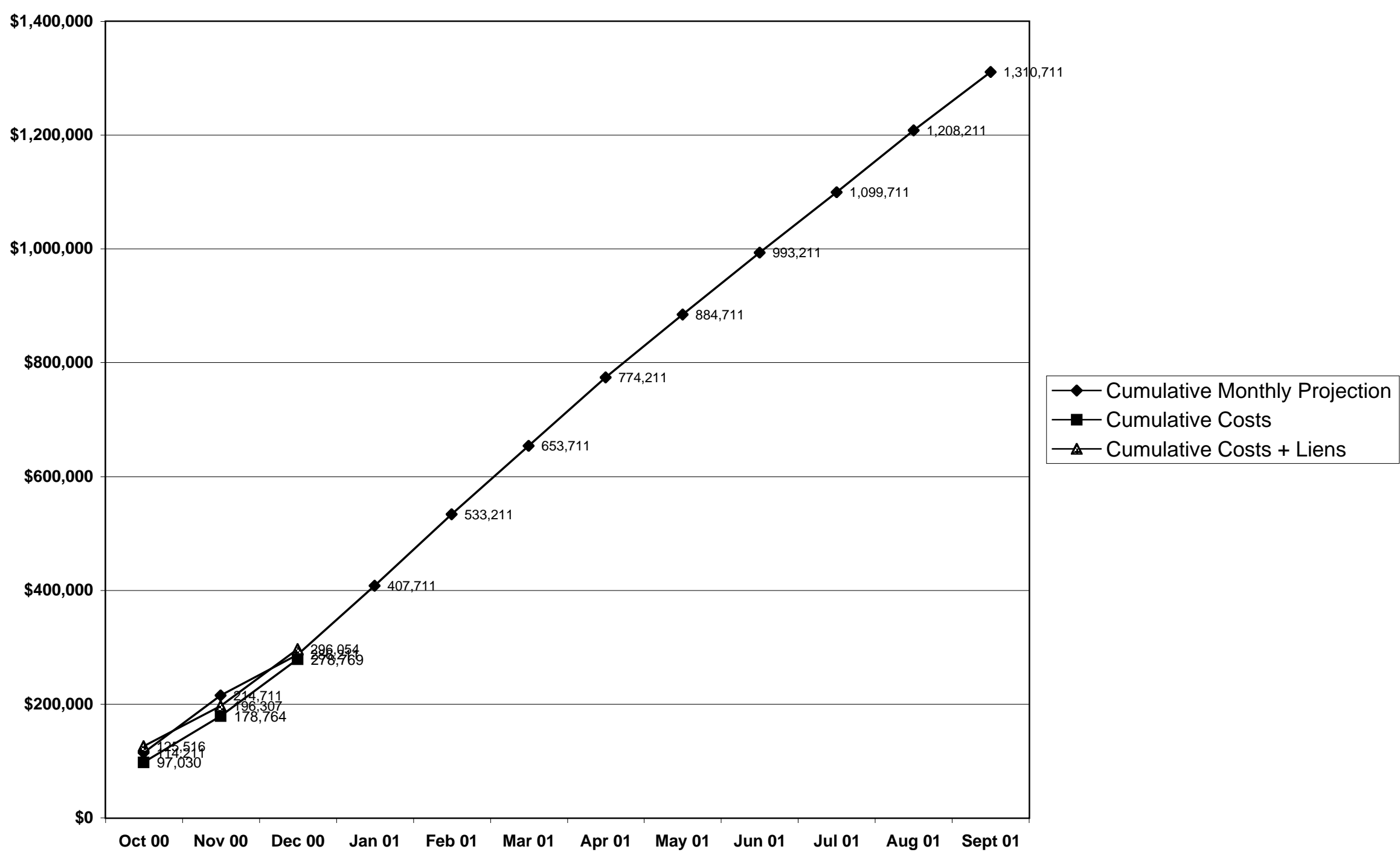


ANL FY01 Spend Plan

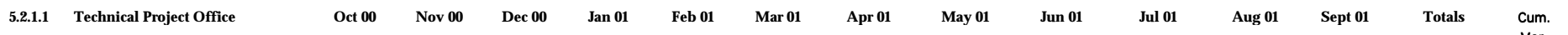

\begin{tabular}{|c|c|c|c|c|c|c|c|c|c|c|c|c|c|c|}
\hline Manpower Projection & 5,500 & 5,500 & 5,500 & 5,500 & 5,500 & 5,500 & 5,500 & 5,500 & 5,500 & 5,500 & 5,500 & 5,500 & & \\
\hline Major Procurement Projection & 0 & 0 & 0 & & 0 & 0 & & & & 0 & 0 & 0 & & \\
\hline FY00 Liens & 0 & 0 & 0 & 0 & 0 & 0 & 0 & 0 & 0 & 0 & 0 & 0 & & \\
\hline Total Monthly Projection & 5,500 & 5,500 & 5,500 & 5,500 & 5,500 & 5,500 & 5,500 & 5,500 & 5,500 & 5,500 & 5,500 & 5,500 & 66,000 & \\
\hline Cumulative Monthly Projection & 5,500 & 11,000 & 16,500 & 22,000 & 27,500 & 33,000 & 38,500 & 44,000 & 49,500 & 55,000 & 60,500 & 66,000 & & \\
\hline \begin{tabular}{|l} 
Cumulative Costs \\
Cumulative Costs +Liens
\end{tabular} & $\begin{array}{l}5,400 \\
5400\end{array}$ & 11,000 & 16,600 & & & & & & & & & & & $\begin{array}{r}-1 \% \\
-1 \%\end{array}$ \\
\hline
\end{tabular}

000 FY01 Funding
0 Comm. C/O

Unob C/O

66,000 Total FY01 Funding

$\begin{array}{lllllllllllllll}\text { 5.2.1.2 Quality Assurance } & \text { Oct } 00 & \text { Nov } 00 & \text { Dec } 00 & \text { Jan } 01 & \text { Feb } 01 & \text { Mar } 01 & \text { Apr } 01 & \text { May } 01 & \text { Jun } 01 & \text { Jul } 01 & \text { Aug } 01 & \text { Sept } 01 & \text { Totals } & \text { Cum. }\end{array}$

\begin{tabular}{|c|c|c|c|c|c|c|c|c|c|c|c|c|c|c|}
\hline Manpower Projection & 10,000 & 10,000 & 8,000 & 20,000 & 25,000 & 25,000 & 25,000 & 20,000 & 18,000 & & & & & \\
\hline Major Procurement Projection & & 0 & 0 & & 0 & & & & & 0 & 0 & & & \\
\hline FY00 Liens & 0 & & 0 & 0 & 0 & & 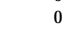 & 0 & & 0 & 0 & & 0 & \\
\hline Total Monthly Projection & 10,000 & 10,000 & 8,000 & 20,000 & 25,000 & 25,000 & 25,000 & 20,000 & 18,000 & 17,000 & 15,000 & 15,000 & 208,000 & \\
\hline Cumulative Monthly Projection & 10,000 & 20,000 & 28,000 & 48,000 & 73,000 & 98,000 & 123,000 & 143,000 & 161,000 & 178,000 & 193,000 & 208,000 & & \\
\hline $\begin{array}{l}\text { Cumulative Costs } \\
\text { Cumpultaive Costs + Liens }\end{array}$ & 10,000 & $\begin{array}{l}19,200 \\
19200\end{array}$ & $\begin{array}{l}28,100 \\
28,100\end{array}-2$ & & & & & & & & & & & $0 \%$ \\
\hline
\end{tabular}

208,000 FY01 Funding

0 Comm. C/O
0 Unob C/O

208,000 Total FY01 Funding

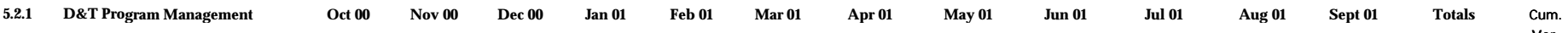

\begin{tabular}{|c|c|c|c|c|c|c|c|c|c|c|c|c|c|c|}
\hline Manpower Projection & 15,500 & 15,500 & 13,500 & 25,500 & 30,500 & 30,500 & 30,500 & 25,500 & 23,500 & 22,500 & 20,500 & 20,500 & 274,000 & \\
\hline Major Procurement Projection & 0 & & 0 & 0 & 0 & 0 & 0 & 0 & 0 & 0 & 0 & 0 & & \\
\hline $\begin{array}{l}\text { FTO0 Liens } \\
\text { Total Monthly Projection }\end{array}$ & $\begin{array}{r}0 \\
15,500\end{array}$ & $\begin{array}{r}0 \\
15,500\end{array}$ & $\begin{array}{r}0 \\
13,500\end{array}$ & $\begin{array}{r}0 \\
25,500\end{array}$ & $\begin{array}{r}0 \\
30,500\end{array}$ & $\begin{array}{r}0 \\
30,500\end{array}$ & $\begin{array}{r}0 \\
30,500\end{array}$ & $\begin{array}{r}0 \\
25.500\end{array}$ & $\begin{array}{r}0 \\
23,500\end{array}$ & $\begin{array}{r}0 \\
22.500\end{array}$ & $\begin{array}{r}0 \\
20,500\end{array}$ & $\begin{array}{r}0 \\
20,500\end{array}$ & $\begin{array}{r}0 \\
274,000\end{array}$ & \\
\hline Cumulative Monthly Projection & 15,500 & 31,000 & 44,500 & 70,000 & 100,500 & 131,000 & 161,500 & 187,000 & 210,500 & 233,000 & 253,500 & 274,000 & & \\
\hline \begin{tabular}{|l} 
Cumulative Costs \\
Cumulative Costs + Liens
\end{tabular} & $\begin{array}{l}15,400 \\
15,400\end{array}$ & $\begin{array}{l}30,200 \\
30,200\end{array}$ & $\begin{array}{l}44,700 \\
44,700\end{array}$ & & & & & & & & & & & $0 \%$ \\
\hline
\end{tabular}

274,000 FY01 Funding 0 Comm. C/O
0 Unob C/O

274,000 Total FY01 Funding

\%е\%

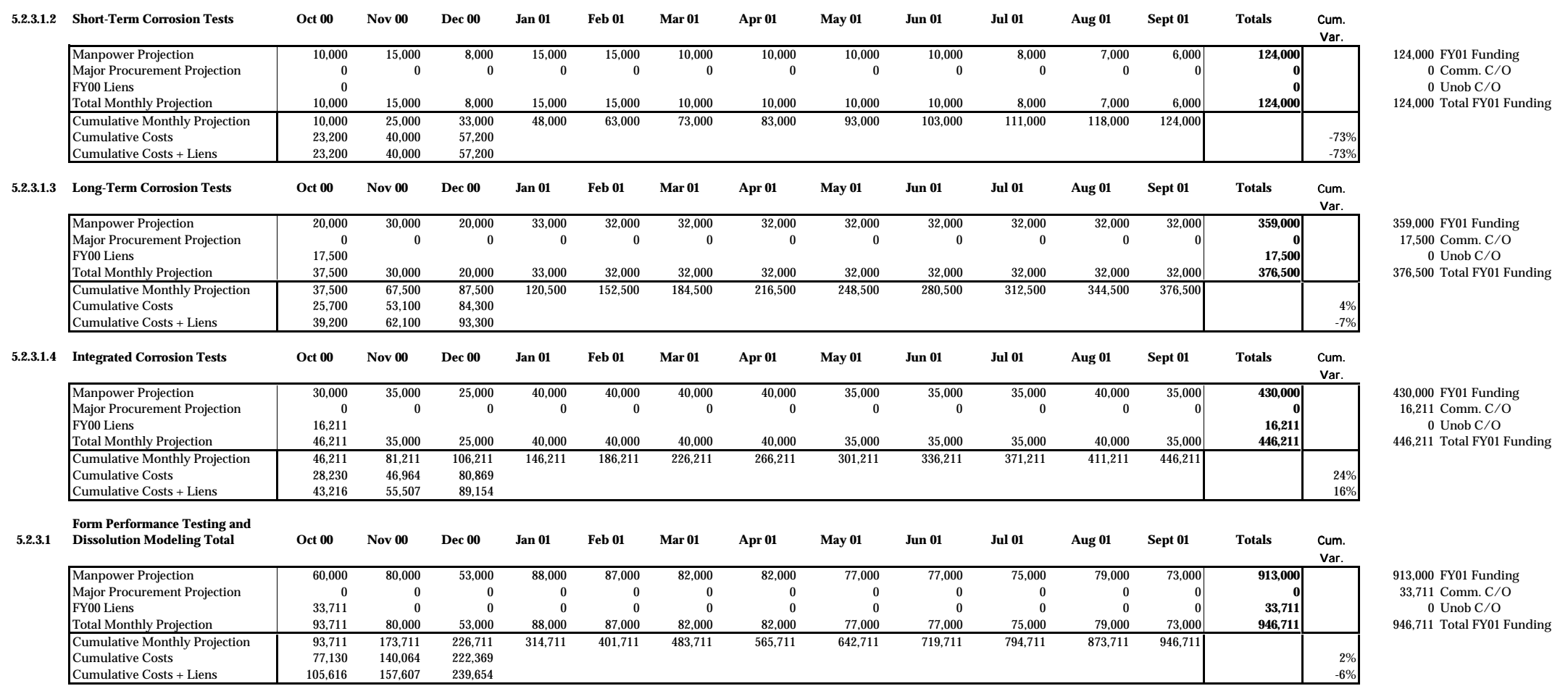




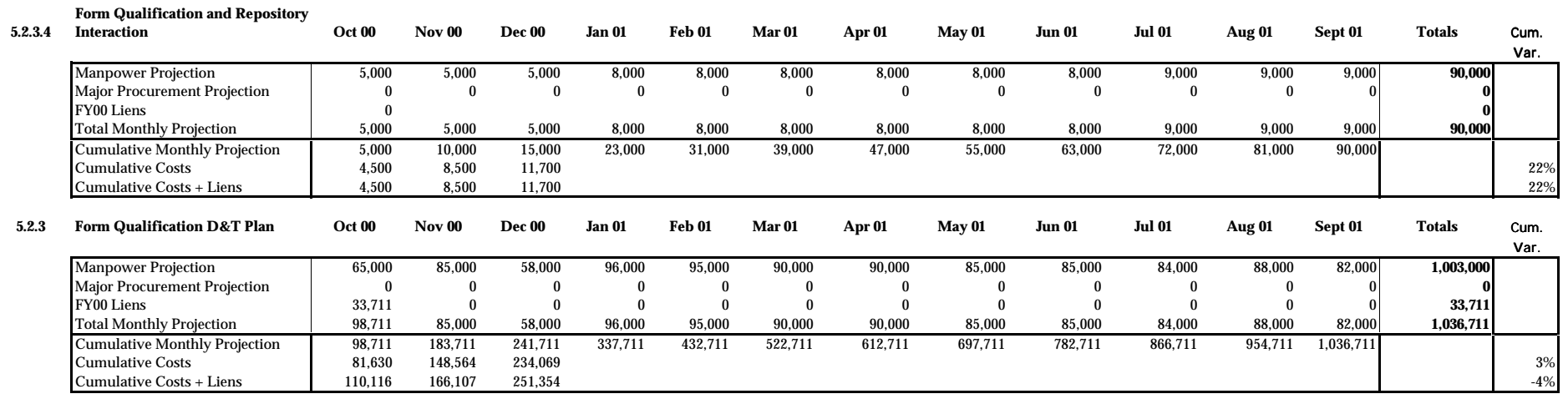

ANL Immobilization and

\begin{tabular}{|c|c|c|c|c|c|c|c|c|c|c|c|c|c|c|}
\hline Associated Processing Total & Oct 00 & Nov 00 & Dec 00 & Jan 01 & Feb 01 & Mar 01 & Apr 01 & May 01 & Jun 01 & Jul 01 & Aug 01 & Sept 01 & Totals & Cum. \\
\hline Manpow & 80,500 & 100,500 & 71,500 & 121,500 & 125,500 & 120,500 & 120,500 & 110,500 & 108,500 & 106,500 & 108,500 & 102,500 & $\begin{array}{ll}1,277,000 \\
\end{array}$ & \\
\hline ment Projection & & & & & & & & & & & & & & \\
\hline FY00 Liens & 33,711 & & & & & & & & & & & & 33,711 & \\
\hline Total Monthly Projection & 114,211 & 100,500 & 71,500 & 121,500 & 125,500 & 120,500 & 120,500 & 110,500 & 108,500 & 106,500 & 108,500 & 102,500 & $1,310,711$ & \\
\hline Cumulative Monthly Projection & $\begin{array}{lll}114,211 \\
07020\end{array}$ & 214,711 & 286,211 & 407,711 & 533,211 & 653,711 & 774,211 & 884,711 & 993,211 & $1,099,711$ & $1,208,211$ & $1,310,711$ & & \\
\hline $\begin{array}{l}\text { Cumulative Costs } \\
\text { Cumulative Costs + Liens }\end{array}$ & $\begin{array}{r}97,030 \\
125,516\end{array}$ & $\begin{array}{l}178,764 \\
196,307\end{array}$ & $\begin{array}{l}278,769 \\
29,054\end{array}$ & & & & & & & & & & & $3 \%$ \\
\hline
\end{tabular}

1,003,000 FY01 Funding 0 Unob C/O 1,036,711 Total FY01 Funding Cumulative 
PNNL - Immobilization

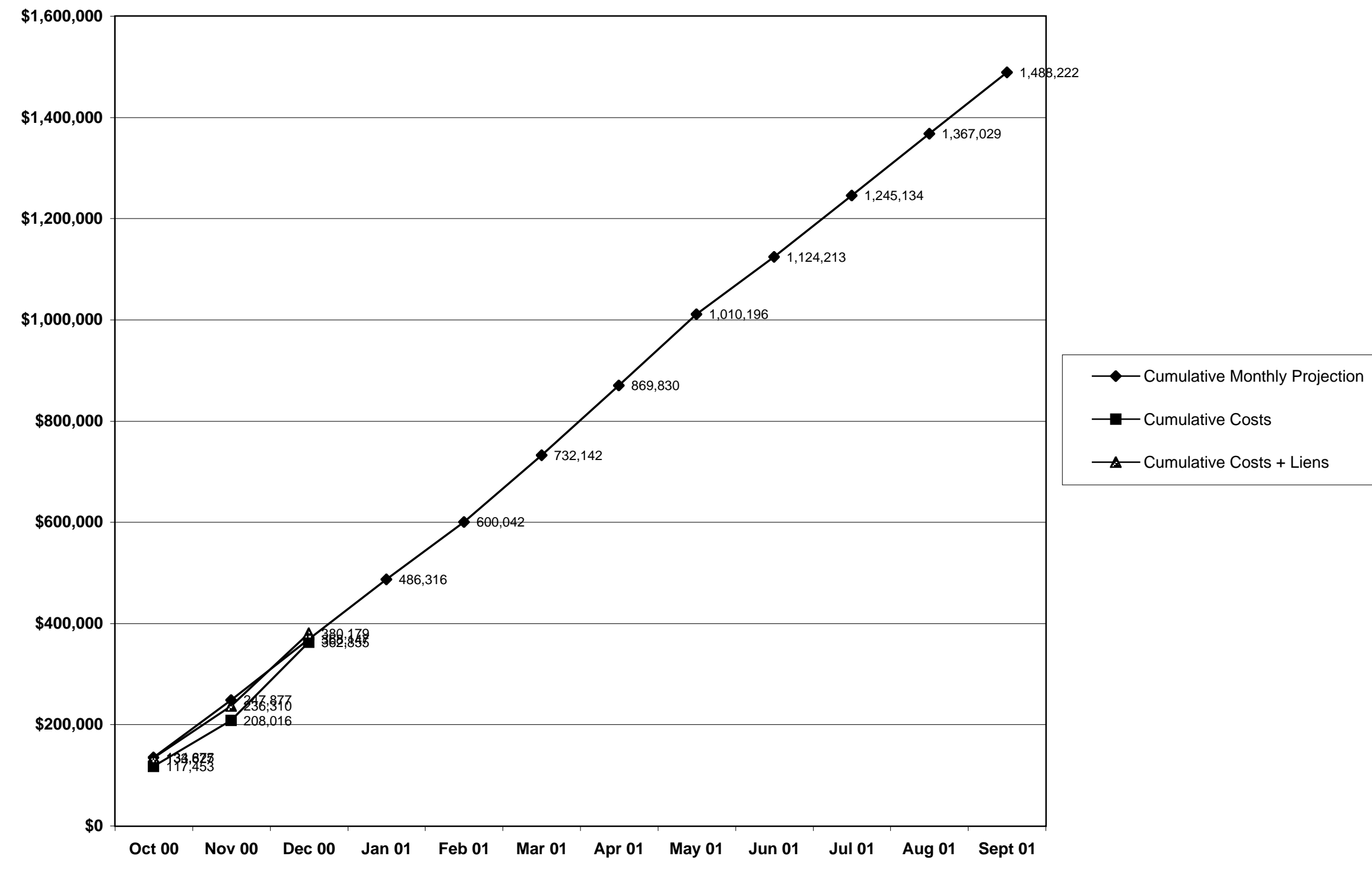


PNNL FY01 Spend Plan

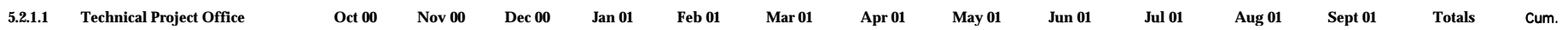

\begin{tabular}{|c|c|c|c|c|c|c|c|c|c|c|c|c|c|}
\hline & & & & & & & & & & & & & \\
\hline \begin{tabular}{|l|} 
Manpower Projection \\
Major Procurement Projection \\
FY00 Liens
\end{tabular} & 703 & 6,232 & 6,871 & 7,956 & 6,871 & 8,456 & 7,594 & 7,956 & 7,594 & 7,732 & 7,232 & 6,803 & $\begin{array}{r}82,000 \\
0 \\
0\end{array}$ \\
\hline \begin{tabular}{|l} 
Total Monthly Projection \\
\end{tabular} & 703 & 6,232 & 6,871 & 7,956 & 6,871 & 8,456 & 7,594 & 7,956 & 7,594 & 7,732 & $\begin{array}{l}7,232 \\
, 207\end{array}$ & 6,803 & \\
\hline $\begin{array}{l}\text { Cumulative Monthly Projection } \\
\text { Cumulative Costs }\end{array}$ & $\begin{array}{l}703 \\
703\end{array}$ & $\begin{array}{l}6,935 \\
7,679\end{array}$ & $\begin{array}{l}13,806 \\
13,534\end{array}$ & 21,762 & 28,633 & 37,089 & 44,683 & 52,639 & 60,233 & 67,965 & 75,197 & 82,000 & \\
\hline Cumulative Costs + Liens & 703 & 7,679 & 13,534 & & & & & & & & & & \\
\hline
\end{tabular}

Funding Totals

82,000 New FY01 Funds 0 Comm. C/O

2,000 Total FY01 Funding

5.2.1.2 $\quad \mathrm{Q}$

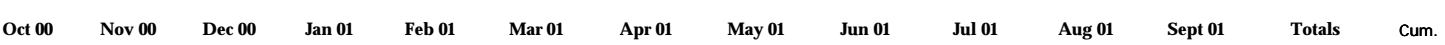

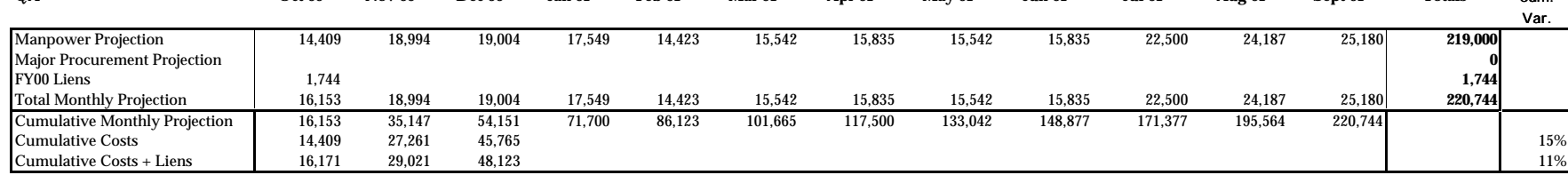

219,000 New FY01 Funds

1,744 Comm. C/O+

0 Unob C/O
220,744 Total FY01 Funding

5.2.1 Project Management Tota

$\begin{array}{lllllllllllll}\text { Oct 00 } & \text { Nov 00 } & \text { Dec 00 } & \text { Jan 01 } & \text { Feb 01 } & \text { Mar 01 } & \text { Apr 01 } & \text { May 01 } & \text { Jun 01 } & \text { Jul 01 } & \text { Aug 01 } & \text { Sept 01 } & \text { Totals }\end{array}$

Cum.

\begin{tabular}{|c|c|c|c|c|c|c|c|c|c|c|c|c|c|}
\hline Manpower Projection & 15,112 & 25,226 & 25,875 & 25,505 & 21,294 & 23,998 & 23,429 & 23,498 & 23,429 & 30,232 & 31,419 & \begin{tabular}{|c|c|}
31,983 \\
\end{tabular} & \\
\hline $\begin{array}{l}\text { Major Procurement Projection } \\
\text { FYoO Liens }\end{array}$ & 0 & 0 & 0 & 0 & 0 & 0 & 0 & 0 & 0 & 0 & 0 & 0 & \\
\hline $\begin{array}{l}\text { FY00 Liens } \\
\text { Total Monthly Projection }\end{array}$ & $\begin{array}{r}1,744 \\
16856\end{array}$ & $\begin{array}{r}0 \\
25,226\end{array}$ & $\begin{array}{r}0 \\
25,875\end{array}$ & $\begin{array}{r}0 \\
25,505\end{array}$ & $\begin{array}{r}0 \\
21,294\end{array}$ & $\begin{array}{r}0 \\
23,998\end{array}$ & $\begin{array}{r}0 \\
23,429\end{array}$ & $\begin{array}{r}0 \\
23,498\end{array}$ & $\begin{array}{r}0 \\
23,429\end{array}$ & $\begin{array}{r}0 \\
30,232\end{array}$ & $\begin{array}{r}0 \\
31,419\end{array}$ & $\begin{array}{r}0 \\
31,983\end{array}$ & 1,744 \\
\hline $\begin{array}{l}\text { Cumulative Monthly Projection } \\
\text { Cumulative Costs }\end{array}$ & $\begin{array}{l}16,856 \\
15,112\end{array}$ & $\begin{array}{l}42,082 \\
34,940\end{array}$ & $\begin{array}{l}67,957 \\
59,299\end{array}$ & 93,462 & 114,756 & 138,754 & 162,183 & 185,681 & 209,1110 & 239,342 & 270,761 & 302,744 & \\
\hline Cumulative Costs + Lien & 16,874 & 36,700 & 61,657 & & & & & & & & & & \\
\hline
\end{tabular}

\begin{tabular}{l|rrr} 
Cumulative Costs & 16,112 & 34,940 & 59,299 \\
Cumulative Costs + Liens & 16,874 & 36,700 & 61,657 \\
\hline
\end{tabular}

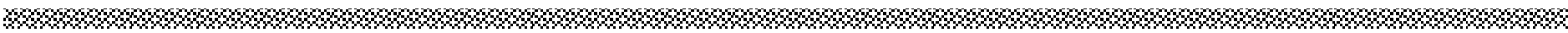

\begin{tabular}{|c|c|c|c|c|c|c|c|c|c|c|c|c|c|c|c|}
\hline 5.2.3.1.1. & $\begin{array}{l}\text { Radiation-Damaged Sample } \\
\text { Synthesis }\end{array}$ & Oct 00 & Nov 00 & Dec 00 & Jan 01 & Feb 01 & Mar 01 & Apr 01 & May 01 & Jun 01 & Jul 01 & Aug 01 & Sept 01 & Totals & $\begin{array}{l}\text { Cum. } \\
\text { Var. }\end{array}$ \\
\hline & \begin{tabular}{|l} 
Manpower Projection \\
Major Procurement Projection \\
FY00 Liens
\end{tabular} & 33,212 & 38,516 & 42,024 & 44,780 & 52,021 & 59,834 & 64,213 & 65,151 & 52,210 & 48,478 & 47,353 & 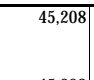 & $\begin{array}{r}593,000 \\
0 \\
0\end{array}$ & \\
\hline & Total Monthly Projection & 33,212 & 38,516 & 42,024 & 44,780 & 52,021 & 59,834 & 64,213 & 65,151 & 52,210 & 48,478 & 47,353 & 45,208 & 593,000 & \\
\hline & $\begin{array}{l}\text { Cumulative Monthly Projection } \\
\text { Cumulative Costs }\end{array}$ & $\begin{array}{l}33,212 \\
33,212\end{array}$ & $\begin{array}{l}71,728 \\
66,671\end{array}$ & $\begin{array}{l}113,752 \\
125,729\end{array}$ & 158,532 & 210,553 & 277,387 & 334,600 & 399,751 & 451,961 & 500,439 & 547,792 & 593,000 & & \\
\hline & Cumulative Costs + Liens & 33,212 & 66,671 & 126,888 & & & & & & & & & & & $2 \%$ \\
\hline 5.2.3.1.4 & Integrated Corrosion Tests & Oct 00 & Nov 00 & Dec 00 & Jan 01 & Feb 01 & Mar 01 & Apr 01 & May 01 & Jun 01 & Jul 01 & Aug 01 & Sept 01 & Totals & $\begin{array}{l}\text { Cum. } \\
\text { Var. }\end{array}$ \\
\hline & \begin{tabular}{|l|} 
Manpower Projection \\
Major Procurement Projection \\
FY00 Liens \\
Total Monthly Projection
\end{tabular} & 10,083 & 11,750 & 10,450 & 8,012 & 1,100 & 1,051 & 1,002 & 928 & 926 & 897 & 902 & 8999 & $\begin{array}{r}48,000 \\
0 \\
0 \\
48,000\end{array}$ & \\
\hline & \begin{tabular}{|l} 
Cumulative Monthly Projection \\
\end{tabular} & $\frac{10,053}{10,083}$ & $\frac{1,1,70}{21,833}$ & $\frac{1,4500}{32,283}$ & $\frac{40,295}{40,295}$ & $\frac{1,1,395}{41,395}$ & $\frac{1,011}{42,446}$ & $\frac{1,002}{43,448}$ & 44,376 & 45,302 & 46,199 & $\frac{02}{47,101}$ & $\frac{1980}{48,000}$ & & \\
\hline & $\begin{array}{l}\text { Cumulative Costs } \\
\text { Cumulative Costs }+ \text { Liens }\end{array}$ & $\begin{array}{l}10,083 \\
10,083 \\
\end{array}$ & $\begin{array}{l}23,009 \\
25,633 \\
\end{array}$ & $\begin{array}{r}35,977 \\
38,601 \\
\end{array}$ & & & & & & & & & & & $\begin{array}{l}1 \% \\
\%\end{array}$ \\
\hline 5.2.3.1.5 & Single-Pass Flow-Through Tests & Oct 00 & Nov 00 & Dec 00 & Jan 01 & Feb 01 & Mar 01 & Apr 01 & May 01 & Jun 01 & Jul 01 & Aug 01 & Sept 01 & Totals & $\begin{array}{l}\text { Cum. } \\
\text { Var. }\end{array}$ \\
\hline & \begin{tabular}{|l|} 
Manpower Projection \\
Major Procurement Projection \\
FY00 Liens
\end{tabular} & $\begin{array}{l}2,144 \\
15,478\end{array}$ & 31,021 & 35,021 & 33,641 & 33,302 & 41,117 & 42,154 & 43,689 & 31,214 & 34,879 & 35,021 & 35,797 & $\begin{array}{r}439,000 \\
0 \\
15,478\end{array}$ & \\
\hline & Total Monthly Projection & & 31,021 & 35,021 & 33,641 & 33,302 & 41,117 & 42,154 & 43,689 & 31,214 & 34,879 & 35,021 & 35,797 & 454,478. & \\
\hline & $\begin{array}{l}\text { Cumulative Monthly Projection } \\
\text { Cumulative Costs }\end{array}$ & $\begin{array}{l}57,622 \\
42,144\end{array}$ & $\begin{array}{l}88,643 \\
62,381\end{array}$ & $\begin{array}{l}123,664 \\
117,449\end{array}$ & 157,305 & 190,607 & 231,724 & \begin{tabular}{ll|}
273,878 \\
\end{tabular} & 317,567 & 348,781 & 383,660 & 418,681 & 454,478 & & \\
\hline & Cumulative Costs + Liens & 56,756 & 86,291 & 128,632 & & & & & & & & & & & \\
\hline
\end{tabular}

593,000 FY01 Funding

0 Comm. C/O

0 Unob C/O
593,000 Total FY01 Funding

48,000 FY01 Funding

0 Comm. C/O $\mathrm{O}^{*}$
$0 \mathrm{Unob}$ C $/ \mathrm{O}$

48,000 Total FY01 Funding

1744 Com FY01 Fund

202,744 Total FYO Funding

439,000 New FY01 Funds

15,478 Comm. C/O

454,478 Total FY01 Funding 


\begin{tabular}{|c|c|c|c|c|c|c|c|c|c|c|c|c|c|c|c|c|}
\hline 5.2.3.2.2.1 & $\begin{array}{l}\text { Aqueous Solubility/Speciation } \\
\text { Measurements }\end{array}$ & Oct 00 & Nov 00 & Dec 00 & Jan 01 & Feb 01 & Mar 01 & Apr 01 & May 01 & Jun 01 & Jul 01 & Aug 01 & Sept 01 & Totals & $\begin{array}{l}\text { Cum. } \\
\text { Var. }\end{array}$ & \multirow[b]{2}{*}{$\begin{array}{l}0 \text { New FY01 Funds } \\
0 \text { Comm. C/O* } \\
0 \text { Unob C C O } \\
0 \text { Total FY01 Funding }\end{array}$} \\
\hline & \begin{tabular}{|l|} 
Manpower Projection \\
Major Procurement Projection \\
Fyoo Liens \\
Total Monthly Projection \\
Cumulative Monthly Projection \\
Cumulative Costs \\
Cumulative Costs + Liens \\
\end{tabular} & $\begin{array}{l}0 \\
0 \\
0 \\
0 \\
\end{array}$ & $\begin{array}{l}0 \\
0 \\
0 \\
0 \\
\end{array}$ & $\begin{array}{l}0 \\
0 \\
0 \\
0 \\
\end{array}$ & $\begin{array}{l}0 \\
0 \\
0 \\
0 \\
\end{array}$ & $\begin{array}{l}0 \\
0 \\
0 \\
0 \\
\end{array}$ & $\begin{array}{l}0 \\
0 \\
0 \\
0 \\
\end{array}$ & $\begin{array}{l}0 \\
0 \\
0 \\
0 \\
\end{array}$ & $\begin{array}{l}0 \\
0 \\
0 \\
0 \\
\end{array}$ & $\begin{array}{l}0 \\
0 \\
0 \\
0 \\
\end{array}$ & $\begin{array}{l}0 \\
0 \\
0 \\
0 \\
\end{array}$ & $\begin{array}{l}0 \\
0 \\
0 \\
0 \\
\end{array}$ & $\begin{array}{l}0 \\
0 \\
0 \\
0\end{array}$ & $\begin{array}{l} \\
0 \\
0 \\
0 \\
\end{array}$ & $\begin{array}{l}\text { \#DIV /0: } \\
\text { \#DIV/0: }\end{array}$ & \\
\hline \multirow[t]{3}{*}{ 5.2.3.1 } & $\begin{array}{l}\text { Form Performance Testing and } \\
\text { Dissolution Modeling }\end{array}$ & Oct 00 & Nov 00 & Dec 00 & Jan 01 & Feb 01 & Mar 01 & Apr 01 & May 01 & Jun 01 & Jul 01 & Aug 01 & Sept 01 & Totals & $\begin{array}{l}\text { Cum. } \\
\text { Var. }\end{array}$ & \multirow{3}{*}{$\begin{array}{c}\text { 1,080,000 New FY01 Funds } \\
15,478 \text { Comm. C/O* } \\
0 \text { Unob C/O } \\
\text { 1,095,478 Total FY01 Funding }\end{array}$} \\
\hline & \begin{tabular}{|l|} 
Manpower Projection \\
Major Procurement Projection \\
FYoo Liens \\
Total Monthly Projection \\
\end{tabular} & $\begin{array}{r}85,439 \\
0 \\
15,478 \\
100,917\end{array}$ & $\begin{array}{r}81,287 \\
0 \\
0 \\
81,287\end{array}$ & $\begin{array}{r}87,495 \\
0 \\
0 \\
87,495\end{array}$ & $\begin{array}{r}86,433 \\
0 \\
0 \\
86,433 \\
\end{array}$ & $\begin{array}{r}86,423 \\
0 \\
0 \\
86,423\end{array}$ & $\begin{array}{r}102,002 \\
0 \\
0 \\
102,002\end{array}$ & $\begin{array}{r}107,369 \\
0 \\
0 \\
107,369\end{array}$ & $\begin{array}{r}109,768 \\
0 \\
0 \\
109,768\end{array}$ & $\begin{array}{r}84,350 \\
0 \\
0 \\
84,350\end{array}$ & $\begin{array}{r}84,254 \\
0 \\
0 \\
84,254\end{array}$ & $\begin{array}{r}83,276 \\
0 \\
0 \\
83,276\end{array}$ & $\begin{array}{r}81,904 \\
0 \\
0 \\
81,904\end{array}$ & \begin{tabular}{r|}
$1,080,000$ \\
0 \\
15,478 \\
$1,095,478$
\end{tabular} & & \\
\hline & \begin{tabular}{|l} 
Cumulative Monthly Projection \\
Cumulative Costs \\
Cumulative Costs + Liens \\
\end{tabular} & $\begin{array}{r}100,917 \\
85,439 \\
100,051 \\
\end{array}$ & $\begin{array}{l}182,204 \\
152,061 \\
178,995 \\
\end{array}$ & $\begin{array}{l}269,699 \\
279,155 \\
294,121 \\
\end{array}$ & 356,132 & 442,555 & 544,557 & 651,926 & 761,694 & 846,044 & 930,298 & $1,013,574$ & $\begin{array}{ll}1,095,478 \\
\end{array}$ & & $\begin{array}{l}-4 \% \\
-9 \%\end{array}$ & \\
\hline \multirow[t]{3}{*}{ 5.2.3.4 } & $\begin{array}{l}\text { Form Qualification and } \\
\text { Repository Interactions }\end{array}$ & Oct 00 & Nov 00 & Dec 00 & Jan 01 & Feb 01 & Mar 01 & Apr 01 & May 01 & Jun 01 & Jul 01 & Aug 01 & Sept 01 & Totals & $\begin{array}{l}\text { Cum. } \\
\text { var. }\end{array}$ & \multirow{4}{*}{$\begin{array}{l}\text { 90,000 New FY01 Funds } \\
\text { 0 Comm. C/O / } \\
0 \text { Unob C/O } \\
\text { 90,000 Total FY01 Funding }\end{array}$} \\
\hline & \begin{tabular}{|l} 
Manpower Projection \\
Major Procurement Projection \\
FYo0 Liens \\
Total Monthly Projection
\end{tabular} & 16,902 & 6,689 & 6,900 & 6,231 & 6,009 & 6,100 & 6,890 & 7,100 & 6,238 & 6,435 & 7,200 & 7,306 & $\begin{array}{r}90,000 \\
0 \\
0 \\
90,000\end{array}$ & & \\
\hline & $\begin{array}{l}\text { Cumulative Monthly Projection } \\
\text { Cumulative Costs } \\
\text { Cumulative Costs + Liens }\end{array}$ & $\begin{array}{l}16,902 \\
16,902 \\
16,902\end{array}$ & $\begin{array}{l}23,1,591 \\
21,015 \\
21,015\end{array}$ & $\begin{array}{l}3,491 \\
24,401 \\
24,401\end{array}$ & 36,722 & 42,731 & 48,831 & 55,721 & 62,821 & 69,059 & 75,494 & 82,694 & 90,000 & & $\begin{array}{l}20 \% \\
20 \% \\
20 \%\end{array}$ & \\
\hline \multirow[t]{4}{*}{5.2 .3} & D\&T Form Qualification Total & Oct 00 & Nov 00 & Dec 00 & Jan 01 & Feb 01 & Mar 01 & Apr 01 & May 01 & Jun 01 & Jul 01 & Aug 01 & Sept 01 & Totals & $\begin{array}{l}\text { Cum. } \\
\text { Var. }\end{array}$ & \\
\hline & \begin{tabular}{|l} 
Manpower Projection \\
Major Procurement Projection \\
FY00 Liens
\end{tabular} & $\begin{array}{r}102,341 \\
0 \\
15,478\end{array}$ & $\begin{array}{r}87,976 \\
0 \\
0\end{array}$ & $\begin{array}{r}94,395 \\
0 \\
0\end{array}$ & $\begin{array}{r}92,664 \\
0 \\
0\end{array}$ & $\begin{array}{r}92,432 \\
0 \\
0\end{array}$ & $\begin{array}{r}108,102 \\
0 \\
0\end{array}$ & $\begin{array}{r}114,259 \\
0 \\
0\end{array}$ & $\begin{array}{r}116,868 \\
0 \\
0\end{array}$ & $\begin{array}{r}90,588 \\
0 \\
0\end{array}$ & $\begin{array}{r}90,689 \\
0 \\
0\end{array}$ & $\begin{array}{r}90,476 \\
0 \\
0\end{array}$ & $\begin{array}{r}89,210 \\
0 \\
0\end{array}$ & $\begin{array}{r}1,170,000 \\
0 \\
15,478\end{array}$ & & \multirow{3}{*}{$\begin{array}{c}\text { 1,170,000 New FY01 Funds } \\
\text { 15,478 Comm. C/O } \\
\text { 0 Unob C/O } \\
\text { 1,185,478 Total FY01 Funding }\end{array}$} \\
\hline & Total Monthly Projection & 117,819 & 87,976 & 94,395 & 92,664 & 92,432 & 108,102 & 114,259 & 116,868 & 90,588 & 90,689 & 90,476 & 89,210 & $\begin{array}{r}1,185,478 \\
\end{array}$ & & \\
\hline & $\begin{array}{l}\text { Cumulative Monthly Projection } \\
\text { Cumulative Costs } \\
\text { Cumulative Costs + Liens }\end{array}$ & $\begin{array}{l}117,819 \\
102,341 \\
116,953\end{array}$ & $\begin{array}{l}205,795 \\
173,076 \\
199,610\end{array}$ & $\begin{array}{l}300,190 \\
303,56 \\
318,522\end{array}$ & 392,854 & 485,286 & 593,388 & 707,647 & 824,515 & 915,103 & $1,005,792$ & $1,096,268$ & $1,185,478$ & & $\begin{array}{l}-1 \% \\
-6 \%\end{array}$ & \\
\hline
\end{tabular}

\begin{tabular}{|c|c|c|c|c|c|c|c|c|c|c|c|c|c|c|c|}
\hline $\begin{array}{l}\text { PNNL Immobilization and } \\
\text { Associated Processing Total }\end{array}$ & Oct 00 & Nov 00 & Dec 00 & Jan 01 & Feb 01 & Mar 01 & Apr 01 & May 01 & Jun 01 & Jul 01 & Aug 01 & Sept 01 & Totals & $\begin{array}{l}\text { Cum. } \\
\text { Var. }\end{array}$ & \multirow{6}{*}{$\begin{array}{c}\text { 1,471,000 FY01 Funding } \\
\text { 17,222 Comm. C/O* } \\
\text { 0 Unob C/O } \\
\text { 1,488,222 Total FY01 Funding }\end{array}$} \\
\hline \begin{tabular}{|l|} 
Manpower Projection \\
Major Procurement Projection
\end{tabular} & $\begin{array}{r}117,453 \\
0\end{array}$ & $\begin{array}{r}113,202 \\
0\end{array}$ & $\begin{array}{r}120,270 \\
0\end{array}$ & $\begin{array}{r}118,169 \\
0\end{array}$ & $\begin{array}{r}113,726 \\
0\end{array}$ & $\begin{array}{r}132,100 \\
0\end{array}$ & $\begin{array}{r}137,688 \\
0\end{array}$ & $\begin{array}{r}140,366 \\
0\end{array}$ & $\begin{array}{r}114,017 \\
0\end{array}$ & $\begin{array}{r}120,921 \\
0\end{array}$ & $\begin{array}{r}121,895 \\
0\end{array}$ & $\begin{array}{r}121,193 \\
0\end{array}$ & $\begin{array}{r}1,471,000 \\
0\end{array}$ & & \\
\hline FY00 Liens & & & & & & & & & & & & & $\begin{array}{r}17,222 \\
118020\end{array}$ & & \\
\hline \begin{tabular}{|l} 
Total Monthly Projection \\
\end{tabular} & 134,675 & 113,202 & 120,270 & 118,169 & 113,726 & 132,100 & 137,688 & 140,366 & 114,017 & 120,921 & 121,895 & 121,193 & $1,488,222$ & & \\
\hline $\begin{array}{l}\text { Cumulative Monthly Projection } \\
\text { Cumulative Costs }\end{array}$ & $\begin{array}{l}134,675 \\
117,453\end{array}$ & $\begin{array}{l}247,877 \\
208,016\end{array}$ & $\begin{array}{l}368,147 \\
362,855\end{array}$ & 486,316 & 600,042 & 732,142 & 869,830 & $1,010,196$ & $1,124,213$ & $1,245,134$ & $1,367,029$ & $1,488,222$ & & $1 \%$ & \\
\hline Cumulative Costs + Liens & 133,827 & 236,310 & 380,179 & & & & & & & & & & & $-3 \%$ & \\
\hline
\end{tabular}

